\title{
Kernos
}

Revue internationale et pluridisciplinaire de religion grecque antique

$17 \mid 2004$

Varia

\section{Epigraphic Bulletin for Greek Religion 2001}

\section{Angelos Chaniotis and Joannis Mylonopoulos}

\section{(2) OpenEdition \\ Journals}

Electronic version

URL: http://journals.openedition.org/kernos/1474

DOI: $10.4000 /$ kernos. 1474

ISSN: 2034-7871

Publisher

Centre international d'étude de la religion grecque antique

Printed version

Date of publication: 1 January 2004

ISSN: 0776-3824

Electronic reference

Angelos Chaniotis and Joannis Mylonopoulos, « Epigraphic Bulletin for Greek Religion 2001 », Kernos [Online], 17 | 2004, Online since 22 April 2011, connection on 16 September 2020. URL : http:// journals.openedition.org/kernos/1474 


\section{Epigraphic Bulletin for Greek Religion 2001 ( $E B G R$ 2001)}

With the 14th issue of the Epigraphic Bulletin for Greek Religion we present a selection of those epigraphic publications of the year 2001 which are connected with the study of Greek religion, but also contribute to the understanding of its cultural context (Oriental cults, Judaism, and Early Christianity); we have also filled some of the gaps from earlier issues (especially EBGR 1999 and 2000). As in earlier bulletins, we have included a small selection of papyrological publications, especially with regard to the study of performative ritual texts ( $\mathrm{n}^{104} 79$ and 194), ancient mythology $\left(\mathrm{n}^{\circ \mathrm{s}} 79\right.$ and 114), divination $\left(\mathrm{n}^{\circ} 85\right)$ and magic $\left(\mathrm{n}^{\circ \mathrm{s}} 85,89-90,108,127\right)$. Despite some omissions, which we intend to cover in the next issue, we hope that the EBGR 2001 gives a representative picture both of new discoveries and of new interpretations.

In this issue we have summarized several regional corpora which were published in 2000 and 2001: we now possess corpora for Rhamnous $\left(n^{\circ} 142\right)$, the Ionian Islands $\left(n^{\circ} 74\right)$, Samos ( $\left.{ }^{\circ} 75\right)$, Pannonia $\left(n^{\circ} 101\right)$, and Side $\left(n^{\circ} 132\right)$. We should also mention the corpus of the Greek-Latin bilingual inscriptions of Asia Minor ( $n^{\circ}$ 94), a corpus of Greek hymns ( $n^{\circ} 62$ ), and two further volumes of the very useful corpus of the epigrams from the Greek East ( $\mathrm{n}^{\prime \prime s} 120$ and 121), which in the meantime has been completed with the publication of the fourth volume (R. MErkelbach - J. Stalder, Steinepigramme aus dem griechischen Osten. Band 4: Die Südküste Klemasiens, Syrien und Palaestina, Leipzig, 2002). Current research trends emerge from the other epigraphic publications. We single out some of the highlights of this issue.

Cult regulations (leges sacrae) are the most important source of information for the study of rituals. The presentation of new Koan leges sacrae (cf. EBGR 2000, 151) continued in 2001 with the publication of six documents that concern the sale of priesthoods ( $\mathrm{n}^{\circ}$ 139). Another significant, but unfortunately fragmentary find, comes from Olympia ( $\mathrm{n}^{\circ} 170$, c. $500 \mathrm{BC}$ ), it seems to regulate the presence of foreigners in the sanctuary of Zeus and damages caused by livestock; the geographical data in a passage of this text probably reflect the itinerary used by the spondophoroi of Olympia who announced the sacred truce. We also mention the new edition of a sacred law from the Cave of Pan at Marathon $\left(n^{\circ} 115\right)$ and a fragmentary epigram whose composer asserts that he did not worship an anonymous god with luxurious offerings and sacrifices of bulls, but with verses, offerings of oak and incense, and the customary sacrifices ( $n^{\circ} 120$ ).

A series of studies on the role of music in ancient cult and the valuable collection of Greek hymns ( $n^{\circ}$ 62) will certainly increase the awareness of the aesthetic aspects of ancient rituals (see especially $n^{\circ} 12$ ). A rather neglected phenomenon in the study of rituals is the effect of war on the regular performance of rituals; this is alluded to in the honorary decree for a military commander in Rhamnous, who "provided sacrificial animals for the sacrifice of the Nemesia and of (to) the king from his own resources, 
when the sacrifices had been neglected because of the war, so that the Rhamnousians could show the proper conduct towards the goddesses" ( $\left.n^{\circ} 142\right)$.

Rituals sometimes are only indirectly inferred from inscriptions. For instance, does

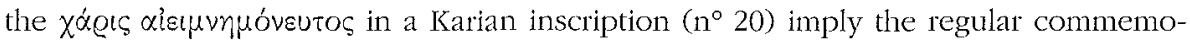
ration of gratitude through ritual actions (e.g., the crowing of a statue)? That the ritual of sacrifice could be felt as a bond which connected two persons and was remembered as a shared experience is demonstrated by an inscription written on the base of a statue of Polydeukion, Herodes Atticus' foster child; Herodes made the dedication to the goddess, "to whom he used to offer sacrifices together with him" (n 142). With regard to divination we draw attention to an interesting case of necromancy and a possible case of a Homeromanteion ( $\left.\mathrm{n}^{\circ} 121\right)$.

Among the new finds which add to our knowledge of piety and individual religious feelings I mention the epigram of Iulia Hagne from Hadrianoi which shows the woman's devotion to the local cults; the epigram states that she died abroad, leaving behind the god of her fatherland $\left(\mathrm{n}^{\circ} 120\right)$. A soldier serving in the garrison at Didymoi in Egypt (c. AD 180-192) reports in graffiti written on two tiles: "I heard in my dreams that I should make the banquet for lord Sarapis; and I made it in expression of gratitude for good fortune" and "I made the banquet for good fortune, in accordance with a dream" ( $\left.\mathrm{n}^{\circ} 45\right)$. The piety of soldiers, persons continually exposed to dangers, certainly needs more attention (see now $\mathrm{n}^{\circ s} 50$ and 142).

Dedicatory inscriptions usually take the lion's share with respect to the expression of personal piety. Among the many new texts we draw attention to a dedication from Korkyra ( $\mathrm{n}^{\circ} 76=I G$ IX $1^{2} 4,844$ ) which clearly reveals how the principle of $d o u t$ des worked: after a seaman had dedicated to Zeus the image of a ship and was blessed by the god with safety, not only did he dedicate a larger image of a ship, but he also promised to dedicate a third one, this time made entirely of gold, should the god also grant him wealth. Less numerous are inscriptions which refer to the lack of piety; in this issue we have two cases of theft of sacred property in inscriptions from Delos and Samos (n's 34 and 75).

Already in the preface of $E B G R 2000$ we called attention to the phenomenon of sacred manumission and the dedication of persons (slaves, alumni, family members) to sanctuaries, two important ritual practices and expressions of personal piety that are almost exclusively documented through inscriptions. In addition to new manumission records from the Kabeirion of Lemnos $\left(n^{\circ} 14\right)$, we should mention two important imterpretative essays on the significance of the consecration of children and slaves in Macedonia and Phrygia ( $\mathrm{n}^{\mathrm{\prime s}} 124$ and 153).

Ancient doctrines and rituals associated with the 'Orphics' have recently attracted a lot of attention. This year's issue includes an important new find, this time from

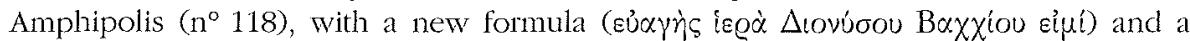
new edition of the lemalle from Hipponion $\left(n^{\circ} 162\right)$. We also mention an article of D. JORDAN ("Written Instructions for the Dead: An Example from Mordovia", ZPE 134 [2001], p. 80, with an addendum in ZPE 137 [2001], p. 34), in which he points to a modern parallel to the Orphic leaves: a present-day funerary lament from Mordovia, which gives instructions to the deceased for his last journey.

The agonistic culture especially of the Hellenistic and Imperial periods is one of the common themes of the $E B G R$. It is basically with epigraphic finds that the various aspects of agons can be clarified, such as undecided victories and victories without competiton ( $\left(n^{\text {nis }} 42-43\right)$ or the acclamations in the stadion during the athletic competitions ( $n^{\circ} 150$ ). The continual publication of new evidence for gladiatorial shows in the 
Greek East calls for a new comprehensive study that would update L. ROBERT's classical work on gladiators in the Roman East. In this context we single out a new letter of Hadrian to Aphrodisias, in which the emperor shows his disapproval of gladiatorial shows ( $\mathrm{n}^{\circ}$ 152: "I concede that you should take money from the high priests instead of gladiatorial shows; not only do I concede but I praise your proposal") and a new interpretation of a relief depicting women gladiators $\left(n^{\circ} 38\right.$; see also $n^{(1)} 87,123,152$, and 160 ).

In recent issues of the $E B G R$ we have often presented evidence for divinities that were regarded as patrons of justice and retribution. We mention a new attestation of the cult of 'Just Gods' (Theoi Dikaioi) in Kibyra ( $\mathrm{n}^{\circ} 39$ ) and an appeal to theodicy: the epigram for Menophantos, who had been murdered, implores Dike and Zeus to console his parents by avenging his death $\left(n^{\circ} 120\right)$.

The study of ancient magic continues to flourish $\left(c f . \mathrm{n}^{\text {is }} 15-16,55-56,71,76,85\right.$, $89-90,108,127,132$, and 141). There are some interesting new finds, especially curse tablets $\left(n^{\circ} 29,71\right.$, and 185$)$ and a new text apparently closely related to the prayers for justice' ( $\left.{ }^{\circ} 29\right)$. One should note the first defixio from Crete, which is unique also in another respect: it is written on a splinter of green steatite $\left(n^{\circ} 71\right)$. Among the new studies we single out a study on the use of nails in magic $\left(n^{\circ} 16\right)$. The use of handbooks in ancient magic has long been known ( $c f . E B G R$ 2000, 58); D. JORDAN has drawn attention to cases in which the copist has by mistake copied not only the formula, but also part of the instructions ( $\mathrm{n}^{\text {os }} 89$ and 91). With regard to curses we mention the public imprecation of enemies of democracy in the Eretrian law against the enemies of democracy $\left(\mathrm{n}^{\circ} 97\right)$.

In the second and third volumes of corpus of epigrams from the Greek east ( $\mathrm{n}^{\mathrm{os}}$ 120-121), but also in other publications ( $\left.\mathrm{n}^{\circ 1} 11,76,94,106,119,132,151\right)$ one will find many expressions of eschatological ideas, that range from the faith in the immortality of the soul $\left(n^{\circ} 76\right)$ to the rejection of the belief of an existence after death $\left(n^{\circ} 132\right)$ : "some claim that after the great trouble of life the souls of the deceased fly in the wide air; this is a myth". The publication of a corpus of Greek-Latin bilingual inscriptions allows some observations on differences of mentality. I point to an epigram, the Latin version of which exploits the common theme of the dwelling of the dead among the Blessed ones, however, not as consolation - as in most Greek epitaphs --, but as scorning of the parents $\left(n^{\circ}\right.$ 94: "you have scorned your father and mother, $O$ most wretched son, since you dwell in the Elysian fields and the meadows of the blessed ones"). A woman who erected a grave altar for her husband, "so that he will be among the future mortals", apparently believed that the performance of the grave rituals on the altar continued the communication between living and dead $\left(n^{\circ} 121\right)$. A similar interest in the continuation of funerary cult is manifest in a long epitaph in Trebenna ( $3 \mathrm{rd}$ cent. AD); the owner of the heroon refers to the instructions he had written in his testament to safegurd the proper conduct of the funerary rites $\left(\mathrm{n}^{\circ} 82\right)$. In this context we remark that a Samian inscription $\left(n^{\circ} 75=I G\right.$ XII 6.1,132) uses of the term thysia in connection with the funeraty cult. Important evidence for heroic cult was found in Halieis - the worship of the Dioskouroi in a private context $\left(n^{\circ} 83\right)$ - and in Messene - the heroic cult of war dead $\left(n^{\circ} 182\right)$.

In the study of the relations between religion and political life, the Hellenistic ruler cult and the emperor cult have been central areas of study (see $\mathrm{n}^{\mathrm{Ns}} 3,22,31$, 31 bis, 39, 41, 51, 69, 75, 77, 92, 94, 132, 140, 142, 161, 165, 167, and 188). An interesting piece of evidence for the rituals of the emperor cult (an old text republished in the corpus of Side) is the grave epigram for a high priestess which describes how she 
appeared in the theater in a purple dress and how her husband, the high priest, placed on her head a crown of gold ( $\left.n^{\circ} 132\right)$; these crowns have been the object of a thorough study $\left(n^{\circ} 159\right)$. How the divinity of the emperor could penetrate the sphere of private religious practices can be seen in a an cpitaph in Kephallenia, in which the appeal to the gods for the protection of the grave is substituted by a reference to the Sebastios borkos, the oath to the genius Augusti $\left(\mathrm{n}^{\circ} 76=I G\right.$ IX $1^{2} 4,1556$, 3rd cent. $\mathrm{AD})$.

The persistence of Hellenic religion in Late Antiquity and the influence of pagan myths, symbols, and vocabulary on early Christianity, but also the religious ambiguities in this period and the interaction between pagans, Christians and Jews, have been noted in earlier issues of the EBGR (see esp. Kemos 13 [2000], p. 128; 14 [2001], p. 147f.; 15 [2002], p. 334; 16 [2003] p. 250). The reader will find also in this issue several inscriptions from Late Antiquity which use a pagan vocabulary or pagan images $\left(n^{n s} 88,120-122\right.$, and 133), evidence for the continuation of pagan practices (e.g., $\mathrm{n}^{\circ} 133$ ), but also many texts which cannot be clearly attributed to a particular religious group because of the use of an ambiguous religious vocabulary ( $\left.\mathrm{n}^{\text {(n) }} 120-121\right)$. New evidence for the various forms of interaction among religious groups - that range from influence to competition and opposition - is primarily provided by inscriptions. They range from a Hellenistic decree in Rhamnous ( $\left.{ }^{\circ} 142\right)$ which concerns the dispute between the priest of Agdistis and a group of persons who tried to hinder his work to the building inscription of a bishop in Korkyra ( $\mathrm{n}^{\circ} 76=I G$ IX $1^{2} 4,1191$, 5th cent.), which aggressively commemorates the destruction of the precincts and altars of the Hellenes, or the epigrams in a family grave which show the co-existence of pagans and Christians within the same family $\left(n^{\circ} 121\right)$. A nice specimen of religious ambiguities is an epigram from Kotiaion that refers to the immortal gods and to the islands of the Blessed in the same context as what seems to be a reference to Christian baptism $\left(\mathrm{n}^{\circ} 121\right)$.

The convergence of the vocabulary of religious expression among the worshippers of the traditional gods, the Jews and the Christians can be observed in particular in grave inscriptions, e.g., in adjurations for the protection of the grave $\left(n^{\circ} 72\right)$ or in the use of Homeric verses in Christian poems $\left(n^{\circ} 88\right)$. An important expression of the henotheistic tendencies in the Imperial Period can be found in the long funerary epigram of Euodos $\left(\mathrm{n}^{\circ} 76=I G \mathrm{IX} 1^{2} 4,1024,2 \mathrm{nd} / 3 \mathrm{rd}\right.$ cent. AD) and in an inscription from Spain $\left(\mathrm{n}^{\circ} 141\right)$. Also the cult of Theos Hypsistos is closely related to henotheism and the complex phenomenon of religious interaction $\left(\mathrm{n}^{\circ} 175\right)$.

The principles explained in Kemos 4 (1991), p. $287-288$ and Kemos 7 (1994), p. 287 also apply to this issue. Abbreviations which are not inclucled in the list of abbreviations are those of L'Année pbilologique and J.H.M. STRuBbe (ed.), Supplementum Epigraphicum Graecum. Consolidated Index for Volumes XXXVI-XLV (19861995), Amsterdam, 1999. If not otherwise specified, clates are B.C. We are very much obliged to Dr. James Cowey for improving the English text. [AC]

\section{Abbreviations}

Agatbos Daimon

$A S T 15$

AST 17

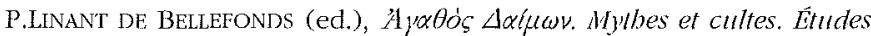
d'iconographie en l'bonneur de Lilly Kabil, Paris, 2000 (BCH Suppl., 38).

15. Arastmma sonuçlam toplantıst, 26-30 Mayts 1997, Ankara, 1998.

17. Arastuma sonuçlar toplanllsl, $24-28$ Majıs 1999, Ankara, Ankara, 2000. 
AST 18

AST19

Chanter les dieux

Greek Personal Names

Hesperia 15

Ilbake

Miscellanea Gasperini

Musique el poésie

Synedrio Epigraphikes I

18. Araşımma sonuçlar toplantıst, 22-26 Mayıs 2000, Izmir, Ankara, 2001.

19. Arasthma somuçan toplantisl, 28 Mayls-01 Haziran 2001, Ankara, Ankara, 2002.

P. BRULÉ - C. VENDRIEs (eds.), Chanter les dieux: Musique et religion dans l'Antiquité grecque et romaine. Actes du colloque des 16, 17 et 18 décembre 1999 (Rennes el Lorient), Rennes, 2001.

S. Hornblowir - E. Matthews (ecls.), Greek Personal Names. Their Value as Evidence, Oxford 2000.

L. BraCCESI - M. Luni (eds.), I Greci in Adriatico, Rome, 2001 (Hesperia, 15).

S. BÖHM - K.-V. VON EICKSTEDT (eds.), Itbake. Festschrift fïr Jörg Scbäfer; Würzburg, 2001.

G. PACI (ed.), 'Eijigoxaí. Miscellanea epigrafica in onore di Lidio Gasperini, Tivoli, 2000.

G.-J. Pinault (ed.), Musique et poéste dans l'antiquité. Actes du colloque de Clemont-Ferrand, Université Blaise Pascal, 23 mai 1997, ClemontFerrand, 2001.

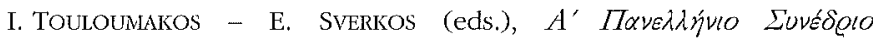

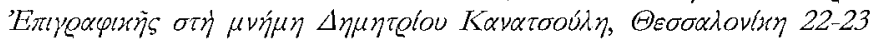

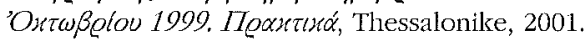

\section{Select Topics}

Geographical areas (in the sequence adopted by $S E G$ )

Athens/Attika: 12-14. 18. 47. 62. 67. 73. 84. 92. 95. 107. 115. 142-144. 168. 171. 178. Epidauria: Epidauros: 62. 168. 195. Troizenia: Halieis: 83; Troizen: 84. Lakonial Sparta: 179. Messenia: Andania: 147; Messene: 145. 180-182. Elis: Olympia: 170. 179. Boiotia: Oropos: 95; Thebes: 46; Thespiai: 24. Delphi: 12. 60. 62. 74-76. 79. 121. 126. 150. 163. Akarnania: Palairos: 57 . Ionian Islands: 76. Thessaly: Pherai: 4. Epeiros: Dodona: 76. 149. 173. Macedonia: 93. 124, 186-187. 190; Amphipolis: 118; Apollonia: 137; Beroia: 125; Dion: 30. 68; Leukopetra: 153; Pella: 35. 110; Thessalonike: 1. 104. Thrace: 69. 183; Augusta Traiana: 125. West Shore of the Black Sea: Histria: 7; Odessos: 169. 177. North Shore of the Black Sea: 103; Chersonesos: 117; Nymphaion: 172; Olbia: 26. 185; Tyras: 37. Delos: 32. 34. 59. 100. Rhodos: 78. 94. Lesbos: Eresos: 94. Kos: 75-76. 111. 139-140. 157. Paros: 62. Samos: 64. 75. 77. Ikaria: 75. Lemnos: 14. Samothrake: 36. Thasos: 66. Euboia: 179; Eretria: 96-98; Karystos: 31. Crete: 33. 62; Knossos: 71; Sybritos: 8. Pannonia: 101. Italy: 44. 148. 189; Aquileia: 23; Rome: 119. 133. 156. 191; Verona: 29. Sicily: Akragas: 48; Katane: 72; Syrakousai: 25. Gaul: 189. Spain: 141. 188. Asia Minor: 31. 94. 120-121. Karia: Alabanda: 22; Aphrodisias: 27. 152; Bargylia: 19-20. 75; Halikarnassos: 38; Labraunda: 192; Mylasa: 20. 22. 28. 160. 192; Olymos: 21. Ionia: Ephesos: 53-54. 86. 94; Erythrai: 62; Miletos: 66. 74. 94; Smyrna: 87. Lydia: Sardis: 102; Pontos: 88; Amaseia: 122-123; Sinope: 122. Phiygia: 2. 124. 153-154; Pessinous: 49. Galatia: 176. Pisidia: 80; Termessos: 81. Pamplyylia: 132. Lykia: 9. 80. 146; Kibyra: 39; Patara: 134; Rhodiapolis: 99; Trebenna: 82. Lykaonia: Laodikeia: 52. Kilikia: Rhosos: 166. Cyprus: 129-130. 135; Paphos: 3. Babylonia: Seleukeia on the Tigris: 188. Israel/Palestina: 106; Gaza: 193; Sidon: 10. 151. Syria: 63. 70. 109. 165; Apameia: 65; Kanatha: 131; Palmyra: 5. Arabia: 164-165. Jordan: 6. Egypt: 50. 105. 113. 128. 155. 167; Alexandria: 15; Didymoi: 45; Leontopolis: 17; Panopolis: 40; Ptolemais Hermiou: 161. Kyrenaika: Apollonia: 116; Kyrene: 51. 184; Ptolemais: 41. 
acclamation: 9.121 .150

aesthetic: see rituals

agon, agonistic festival: 42-43. 75-76, 132. 150. 159; Antoninianos Heleios Leontios Isantinoios agon hieros eiselastikos 17 (Leontopolis); Artemisia: 86 (Ephesos). 97 (Eretria); Asklepieia: 140 (Kos); Attaleia: 140 (Kos); Diogeneia: 142. 144 (Rhamnous); Eukratous Koinos Pontou Isaktios: 132 (Neokaisareia); Hadrianeia: 132 (Antiocheia pros Daphnen); Helieia: 75 (Rhodos); Heraia: 75 (Samos); Herakleia: 121 (Vasada); Isokapitolios: 132 (Hermoupolis); Isthmia: 75. 150; Kaisareia: 75 (Korinthos); Lysandreia: 75 (Samos); Megala Sebasta Heraia: 75 (Samos); Mouseia: 24 (Thespiai); Mystikos: 132 (Side); Nemea: 132; Olympia: 75-76 (Olympia). 193 (Gaza); Panathenaia: 103. 116. 136; Ptolemaia: 142. 144 (Rhamnous); Pythia: 75. 150. 163. 181 (Delphi). 132 (Side). 140 (Kos); Rhomaia: 75 (Miletos); Rhomaia kai Attaleia: 75 (Samos); Sebasmia: 132 (Damaskos); Sebasta Kaisareia: 75 (Samos); Sebereia Peraseia: 132 (Kastabala); Soteria: 163 (Delphi); see also festival

Alexandros of Abonouteichos: 158

altar: 28. 44. 49. 75-76, 110. 120-121. 132. 139. 142. 166-167

ambiguity, in religious texts: 72. 88. 120-121. 189

amphictyony: 163

amulet: 56. 91. 133. 189

animals: dog: 40; dove: 27 ; eagle: 40 ; snake: 76

Apollonios of Tyana: 158

apotropaic inscriptions, deities: 132-133. 169

association, cult: $75-76.104 .142$

asylia: $27.75-76.157$

athletes: $15.42-43.75-76.132 .150$

banquet: 45.75 .104

bell: 133

benediction: 128.150

calendar: 64. (Samos)

cave: 76.115

Christianity: 76. 88. 119-121; and magic: 16. 133. 171. 189; pagan influences on C.: 88. 120-122. 133

chthonic cult: 48

clothes: 132 (purple dress); prohibitions with regard to c.: 115.120

confession inscription: 94

consecration, of children: 124.153 ; of slaves: 124.153

crown: 75 . 132. 159. 180; crowning, of altar: 75 ?; of statue: 20 ?

cult,; of mortals: 75 (Lysandros). 142 (Diogenes); opposition against c.: 32. 14́2; see also ruler cult

cult personnel: agonothetes: $75-76,132.159$; agoratros: 163; akrobates: 53 ; aozos: 76 ; archiereia of the civic emperor cult: 132; archiereus of the civic emperor cult: 31. 69. 75-76. 121. 132. 152. 159-160. 180; archiereus of the emperor cult: 159; in Arabia: 165; in Asia: 121; in Lykia: 99; in Macedonia: 125; archineokoros: 104; archiskeptouchos: 76; boones: 14; chrysophoros: 53; demiourgos: 75; epimenios: 75. 140; essenes: 53; exegetes Eumolpidon: 75; hageter theon: 181; hiereia: 
58. 76. 82. 97. 142-143; hiereus: 14. 75. 97. 104. 120-121. 125-126. 130. 139. 142; hierokeryx: 14. 75; hieromnemon: 14. 132. 163; hieropoios: 14. 76. 100. 142; hieros: 53; hierourgos: 75; hypostates 142; kanephoros: 167; kosmeteira: 53; kosmetes: 14; kosmophoros: 53; lithophoros: 66; mageiros: 76; mantis: 14 ; melissai: 53; molpos: 66; neopoios/neopoies: 34. 53. 75. 140; oikonomos: 53; oinochoos: 76 ; polos: 120 ; propolos: 153 ; prospolos: 181 ; pylagoras: 163 ; speirophoros: 53; tamias ton hieron chrematon 14; tamias ton hosion: 75; theokolos: 76; zakoros: 132; see also Greek words

curse, curse tablet: $26.29 .55-56.71 .75-76.90 .97 .101 .148 .185 .189$; see also funerary imprecation

dance: $66 ; 75$ (chorostates)

dedications: $19.75-76.112 .120-121.142 .146$; by athletes: 132 ; by friends: 80 ; by magistrates: 76. 143. 181; by priests/priestesses: 19. 70 (to another god). 143. 166. 182; brought to the sanctuary on behalf of the dedicant: 146 ; on behalf of family members: 76.112 ; after a dream: 120; after divine punishment: 153; upon divine command: 44.120-121. 132. 153; of statues of family members: 75 ; of weapons: 142 . 182; collection of $\mathrm{d}$. in literary works: 75 ; see also inventory

deities: Aiolos: 110. Aphrodite: 3. 25. 27. 76. 110. 120. 132. 143; Hegemone 142-143. Apollon: 12. 23. 47. 59. 62. 66. 74-76. 79. 93. 120-121. 140. 142. 184. 186; Daphnephoros 98; Hosios 121; Kendrisos 69; Keraites 66; Kerkyraios 75; Klarios 120. 141; Ktistes 132; Lairbenos 124. 153; Lykeios 142; Nomios 93; Nymphegetes 66. 75; Patrios 132; Patroios 132. 134; Pythios 76. 126. 150. 161; Soter 120; Sozon 121. Ares: 40. 80. 121; Epiphanestatos 132. Artemis: 33. 62. 68-69. 75-76. 93. 98. 121. 132. 142. 150. 184; Agrotera 142; Amarynthia 97-98; Eileithyia 68; Ephesia 23. 53-54. 86. 94. 101; Ereitbos 73; Kindyas 75; Oinaia 73; Opitais 76; Protbyraia 150; Soteira 142; Tauropolos 75. Asklepios: 62. 69. 75-76. 101. 111. 120. 139. 157. 161. 168. 181; Hagios 70; Merres 44; Mesioriskos 93; Soter 101. 120; Thybris 156. Athena: 18. 76. 101. 120. 132; Athenon medeousa 75. 84; Boulaia 132; Lindia 78. 94; Nike 67; Polias 76. 136. Britomartis: 33. Charites: 120.

Daimon: Agathos 28. Demeter: 13. 19. 48. 75-76. 132. 142. 180. 182; Horaia 48. Demos: 107 . Dikaion: 121 . Dike: 120 . Dikes Ophthalmos: 121. Diktynna: 33. 174. Dionysos: 62. 75. 94-95. 104. 120. 132. 139. 142. 144. 166. 172. 194; Bakcbios 118; Bromios 120; Eleutbereus 73; Geron 75; Lenaios 142. Dioskouroi: 76.83 .105 .132 .182 . Dynamis: 66. Eileithyia: 33; Inatie 33; see also Artemis. Erinyes: 82. 121. Eros: 75. Hades: 40. Hekate: 10. 66. 150; Sossis 22; Tyche 28. Helios: 121. 177. 183. 186; Basileus 121. Hephaistos: 120. 138. Hera: 69. 75. 77; Akria 76; Teleia 76. Herakles: 75-76. 132. 137. 181-182; Kallinikos 105. 169. Hermes: 8. 26. 66. 75-76. 117. 121. 137. 142.182; Chthonios 26; Enagonios 139. Hestia: 62. Homonoia: 111. Horai: 28. Hosion: 121. Hosion kai Dikaion: 121. Hygieia: 62. 69. 76. 101. 111. Kabeiroi: 14. 46. 183. Kore: 13. 19. 76. 142. 182. Kosmos (?): 49. Kourotrophos: 75. Kronos: 105. Mes: Askainos 121; Dikaios 121. Ouarathes: 82. 146. Meter Oreia: 183. Meter Theon: 62. 110. 121. 142. 153. 195. Mousai: 76. 121; Pimpleides 30. Nemesis: 49, 75. 87. 92, 121. 142-143. Nike: 84. Nymphai: 66. 75-76. 95. 107. 115. 120-121. 132. Pan: 62. 115; Eubodos 105. Pantes Theoi: 62. 76. 132. 181-182. Persephone: 48. Poseidon: 40. 114. 120. 138; Asphateios 84. 32; Helikonios 75; Soler 142. Telesphoros: 62. Thea Rhome: 75. 132. 142. Themis: 132. 142-143. Theoi Dikaioi: 39. Theoi Heroes: 94. Theoi Katachthonioi: 94. Theoi Megaloi: 36. 132. 190. Theoi Samothrakes / en Samothrake: 7. 36. Theion: 121. Theos 
Megas: 177. Theos Hypsistos: 120-121. 129-130. 175-176. Thesmos: 121. Thetis: 76. Tyche: 76; Hekate 28. Zeus: 2. 30. 40. 52. 69. 75-76. 83. 94. 120-121. 141; Alexikakos 120; Alsenos 121. 154; Ammon 120; Archagathos 120; Aspidios 132; Bennios 94. 121; Bronton 121; Diktaios 62; Dionysos Gongylos 104; Disabetes 120; Dodones medeon 76; Herkeios 142; Hyperdexios 117; Hypsistos 76. 175; Ithomatas 180. 182; Kapitolinos 75; Kassios 76; Keraunios 75; Kersoullos 94. 120; Ktesios 117; Megistos 131; Naios 76. 149. 173; Nikator 132; Olympios 170; Osogo 21; Ourios 120; Panbypsistos 121; Pankrates 84; Polieus 75; Sabazios 125; Solymeus 82; Soter 81. 137. 142; Thallos 2. 23

deities, Anatolian: Ouarathes 82; Egyptian: 14-15. 32. 44. 50. 68. 75-76. 104-105. 113. 120. 132. 141-142. 145. 155. 161. 177; Oriental: Agdistis 121. 142-143; Attis 142; Iao 141; Kybele 49. 142; Manbog 109; Mithras 10. 63. 65. 70; Sabazios 125; Syria Theos 75; Theos Rhabbou 131; Thracian: Darzalas 177; Rider God 69

deities, patrons of agriculture: 16.39; of childbirth: 68; of fertility: 73.121 ; of healing: 142. 174; of hunting: 174 ; of livestock: 121,142 ; of seafaring: 76.132 .149 .174 ; of travellers: 121 ; of victory: 15

deities, assimilation of: 23. 44. 68. 70. 105; criticism on: 121; personifications: see Demos, Dikaion, Dike, Dynamis, Homonoia, Hosion, Kosmos, Thesmos, Tyche; return of: 66

Dionysiac artists: 3. 12. 191

divination: 76, 85. 120-121, 146. 179; Homeromanteion: 121

dream: 120

Eleusinian mysteries: 144

emperor cult: 22.31 .31 bis. 39. 69. 75. 77. 92. 94. 132. 142. 161. 165; assimilation of emperors and gods: 75 (Hadrian Zeus Olympios Epiphanes Soter Ktistes; Augustus/Zeus Polieus?, Tiberius/Zeus Polieus?, Drusilla/Nea Charis). 94 (Livia/ Aphrodite Geneteira); see also neokoreia

ephebes: 17. 20. 75. 115. 117. 167

Epicureans: 121

epiphany: 78

eschatology: 11. 76. 94. 106. 119-121. 132. 151

exorcism: 16

festivals: 147; in Aphrodisias: 27; Artemisia: 86 (Ephesos); choes: 120; Dionysia: 75 (Samos). 76 (Korkyra). 97 (Eretria). 139 (Kos). 142 (Rhamnous). 178 (Thorikos); Theodaisia: 33 (Crete); established after victory: 75

fire: 16

food offerings: 75

foreigners, prohibitions against $f .: 170$

foundation: 76

funerary cult: $20.35 .61 .75-76.82 .93-94.104 .120-122.133 .135$; burial of war dead: 182; dedication of $\mathrm{f}$. monuments to gods: 120-121; f. imprecation: 82. 120-121; prohibition of burial: 97; protection of grave: 72.76

gem: 15.90 .101

gladiators: 38.87 .123 .152 .160

gymnasium: 75-76. 137. 150. 182

hand, raised: 141

healing: 70. 112. 120-121. 142. 156; healing miracle: 168 
henotheism: 76. 141

heroic cult: 25 (Diomedes). 37 (Achilleus). 75 (Ion, Pandion, Athenian eponymous heroes). 76 (of war dead, Alkyniatas, Odysseus). 83 (Dioskouroi). 142 (Heros Archegetes, Aristomachos, Amphiaraos, Iatros). 144 (Heros Archegetes). 150 (Palaimon); rider h.: 187; heroes as ancestors: 181 (Herakles)

heroisation: 120.182

holy man: 158

Homer: 4. 40. 55-56.76. 88. 121-122. 194

hymn: 62. 120-121. 142. 194-195; see also paean

incantation: 55

incence: 120.139

inventory: 75.78

invocation: 101

Jews: 72. 102. 121. 141. 175

justice: 39 (Theoi Dikaioi); see also 'prayer for justice', punishment

Kallimachos: 33

killing, justification of: 9.97

ktistes: 76 (Chersikrates). 121 (Kineas)

land, sacred: 21.51 .75 .94 .142 .192

lex sacra: $61.66 .75-76.115 .120 .139 .142 .147 .168 .170$

libation: 51.120

lightning: 121

magic: $15-16.55-56.71 .76 .85 .89-90.108 .127 .132 .141$; use of nails in m.: 16

manumission, sacred: 126.153

mask: 133

music: 12. 26. 30. 58. 66. 147; see also hymn, paean

mystery cult: $36,46.75,118,120.144$

mythology: 4. 12. 38. 76. 95. 114. 121

nail: 16.133

names, theophoric: 49. 96. 109. 138. 146 (Kledonios?); of priests: 121; related to cult offices: 142 (Hieropoios); districts named after a god/a sanctuary: 132

neokoreia: 86 (Ephesos). 132 (Side)

numbers: 75 (seven)

oath: 75.76 (Seabstios horkos)

oracle: $76.120-121.132 .158$

Orphics: 118, 162. 183

paean: 12. 62. 66. 79. 161

paganism in Late Antiquity: 10. 76-77

papyri: 79. 114. 194; magical: 16, 85. 89-90. 108. 127

personifications: Tetartaios: 75

phylactery: 90. 101

piety: 120. 142-143

pilgrimage: 121

pollution: 97; see also purity

prayer: 16. 121; 'prayer for justice': 29. 189 
priests: families of p.: 132. 184; founders of agons: 132; p. for life: 132. 180; pentaeteric priests: 132

priestood, accumulation of: 132; jubilee of priesthood: 132, sale of: 75.139

procession: 66. 87. 120.140, 167. 181

protective function of seals: 128

punishment, divine: 76.82 .120 .153

purity, purification: 61 ; purity of the mind: 132 ; see also pollution

rituals: 120; aesthetic of r.: 12. 140; see also banquet, crowning

river god: 80.96

ruler cult: Alexander IV: 75; Antigonos Gonatas: 142; Antigonos Monophthalmos: 75; Arsinoe II: 167; Attalids: 75. 140; Demetrios Poliorketes: 75; Phila: 75; Philippos Arrhidaios: 75; Ptolemies: 3. 41. 51. 75. 142. 167; Seleukids: 132. 188; in the gymnasium: 75

sactifice: $51.75-76,120,139-140,142-143.157 .167-168$; criticism on s.: 120; sacrificial animal: 75 (cow). 76 (trittoia). 167-168 (sheep); sacrificial calke: 75; sacrificial regulation: 75

sacrilege: 46 ; see theft

Sanctuaries: 53 (Artemision of Ephesos). 69 (in Thrace). 75 (Heraion of Samos); boundary stones of: 75-76. 142. 186; building works in: 14. 27. 52. 67. 74-76. 94. 140. 142; dedication of children and slaves: 124.153 ; destruction by Christians: 76. 145; finances of: $18.34 .53 .75-76.124 .139$; foundation of: 155 ; guarding of s.: 75. 142; land of: 21. 51. 75. 94. 142. 192; Panhellenic: 60; payment of fines to s.: 82. 97; political role: 60 (arbitration); plundering of: 75; protection of: 75 . 139; prohibitions against the presence of animals: 139. 170; relations to city: 192; trade in s.: 75; treasure: 139; see also asylia, theft

secrecy: 46

slaves, sacred: 153

snake: 76

soldiers, cultic activities of: $3.6,45.50 .63 .76,105.134 .142-144.164 .182$

soul: 76. 106. 120-121; see also eschatology

statue, cult: 27.47 .80 .167 ; bound: 121 ; carried in processions: 87.181 ; protective: 121

subscription, for religious projects: 74-75, 140. 142

suicicle: 94

table, cult: 142.144

temple, opening of: 139

theft of sacred property: 34.75

theoria, theoros: 132.157 .170

theorodokos: 179

truce: 60.157 .170 .179

vow: $2.49 .76 .80,121,130.142 .146 .153$

war: $60,75-76,120.142,182$

water: 75

wine: 142

woman: 58. 120 


\section{Greek Words}

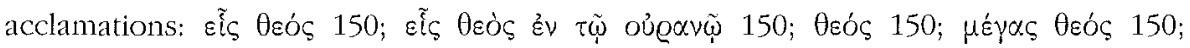

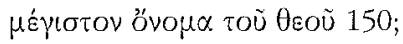

associations: 'A

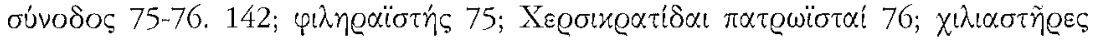

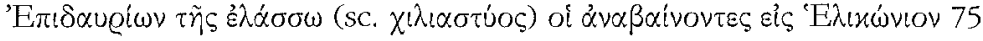

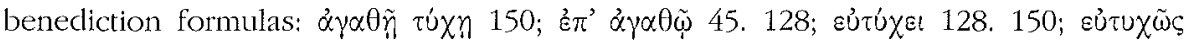

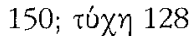

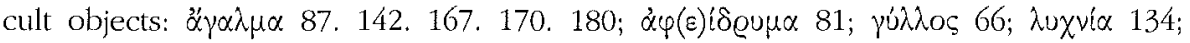

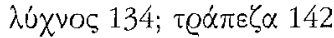

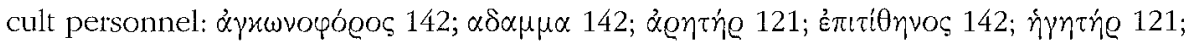

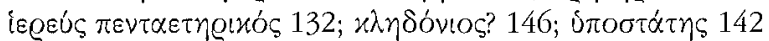

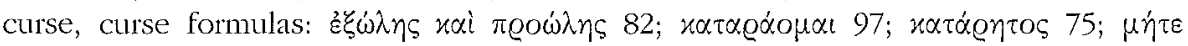

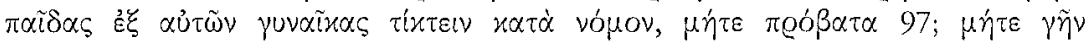

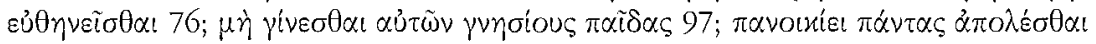

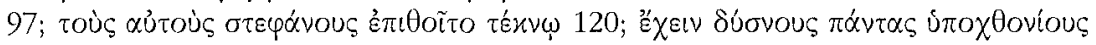

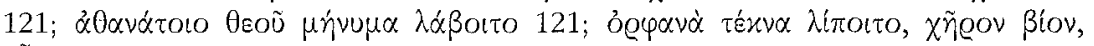

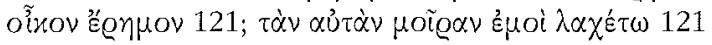

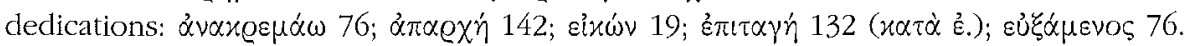

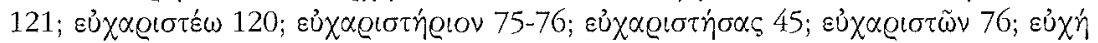

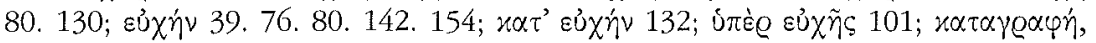

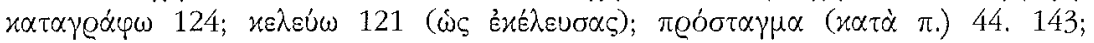

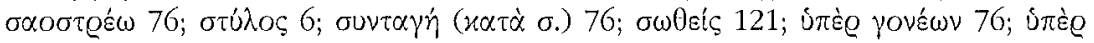

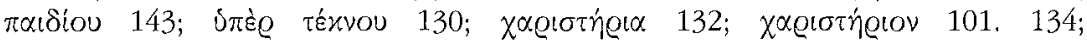

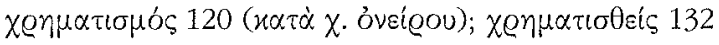

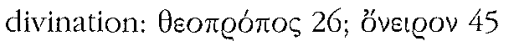

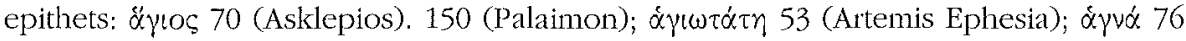

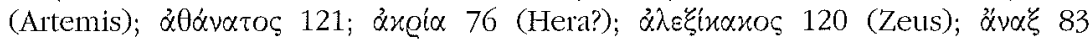

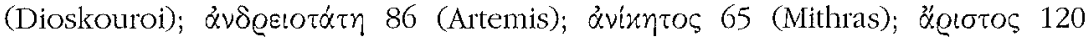

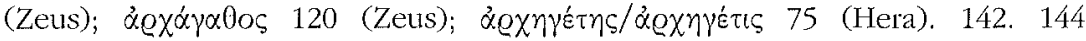

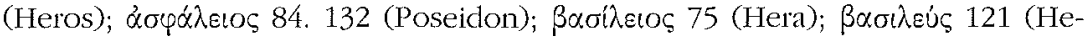

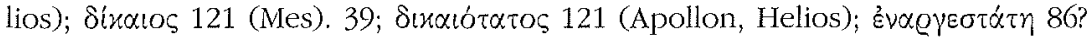

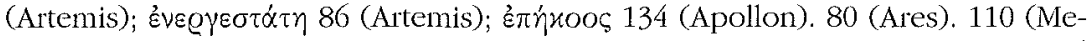

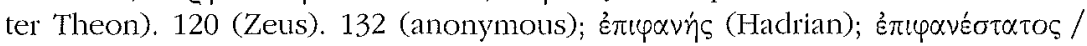

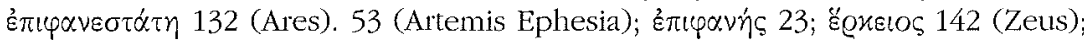

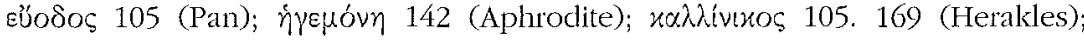

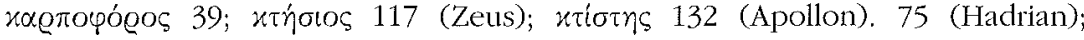
xúgloç/xugi $\alpha$ 53-54 (Artemis Ephesia). 45 (Sarapis). 129 (Theos Hypsistos); $\lambda o \chi^{i \alpha} 68$ (Isis); $\mu \dot{\varepsilon} \gamma \alpha \varsigma / \mu \varepsilon \gamma \alpha \dot{\alpha} \eta \eta 150$ (Apollon). 53.150 (Artemis). 80 (Ares). 120 (Bakchos). 150 (Hekate), 132 (Isis, Sarapis), 121 (Zeus), 81. 132. 177 (anony-

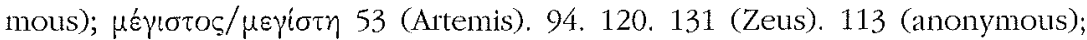

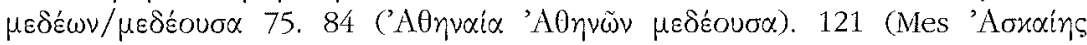

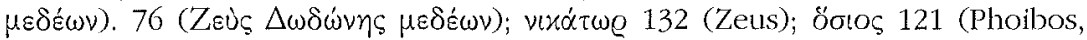

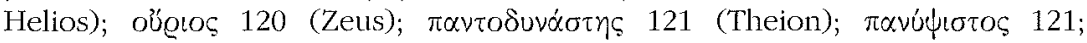

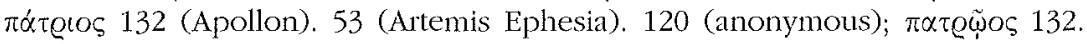
134 (Apollon); $\pi 0 \lambda \varepsilon \mu \iota \omega \tau \dot{\alpha} \tau \eta$ 86 (Artemis); $\sigma \omega \dot{\zeta} \omega \nu \nu 121$ (Apollon). 70 (Potamos

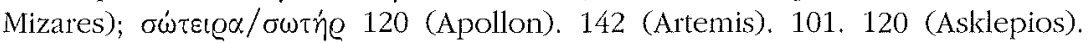
142. 144 (Athena). 75 (Hadrian), 142 (Poseidon). 75 (Ptolemies). 81. 94. 120. 


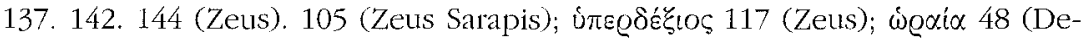
meter). 73 (Artemis)

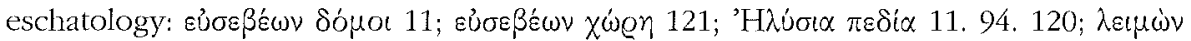

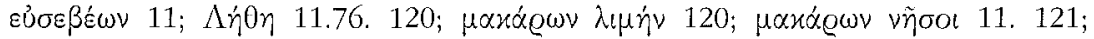

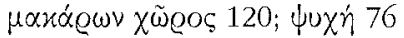

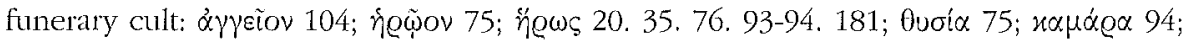

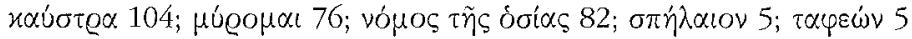

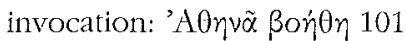

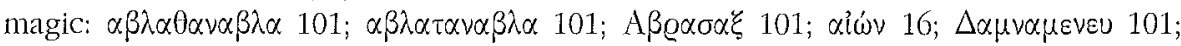

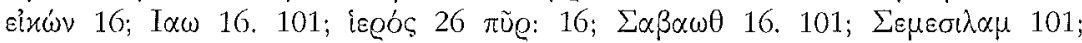

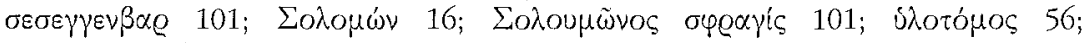

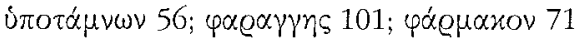

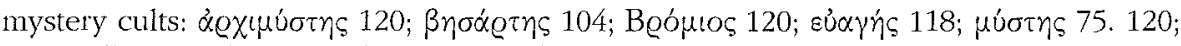
ö@ 14

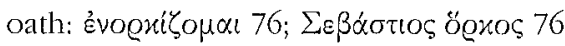

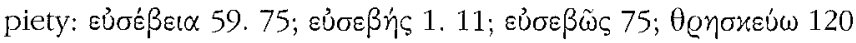

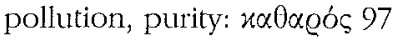

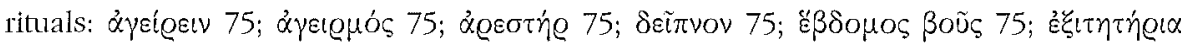

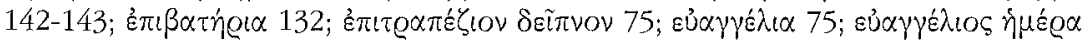

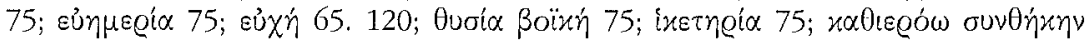

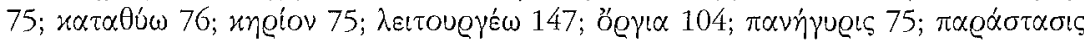

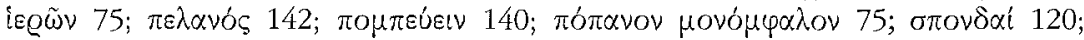

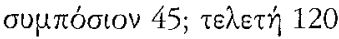

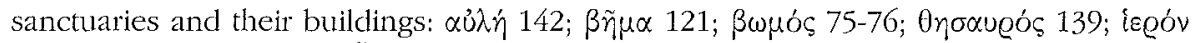

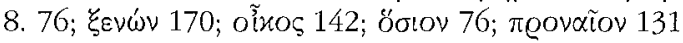

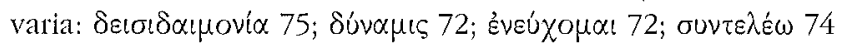

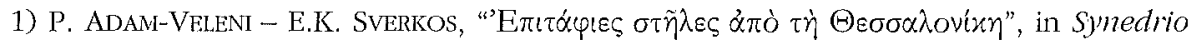
Epigrapbikes I, p. 13-34 [German summary]: Ed. pr. of 6 epitaphs from Thessalonike. In one

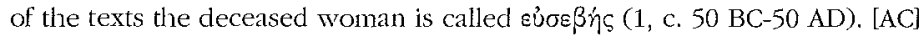

2) N.E. AKYÜrek SAHIN, "Phrygische Votive aus dem archäologischen Museum von Istanbul", $E A 33$ (2001), p. 185-193 [BE 2002, 420]: A. publishes ten small fragmentary dedications to Zeus found in Phrygia and now kept at the Archaeological Museum of Istanbul. Only one of these objects bears a dedicatory inscription (SEG XXXII 1282; XXXIII 1156, c. AD 180-220). It is the dedication of a bronze-smith to Zeus Thallos in fulfillment of a vow. [JM]

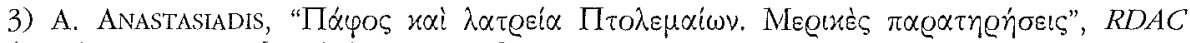
(2001), p. 223-231 [English summary]: A. collects the evidence for the cult of the Ptolemies in Paphos and underlines the role played by the officers and soldiers on the one hand and the association of Dionysiac artists on the other in the promotion of this cult through dedications; [A. makes no distinction between dedications and honorary inscriptions; some of the material he has collected is irrelevant for the ruler cult]. A. argues that the Ptolemies tried to associate their cult with the sanctuary of Aphrodite. $[\mathrm{AC}]$

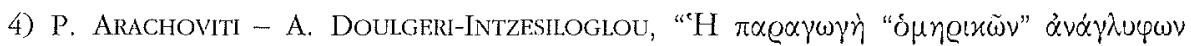

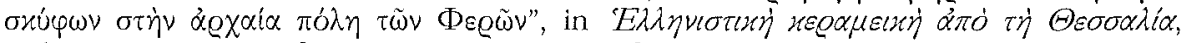
Volos, 2000, p. 70-80 [BE 2002, 100; SEG L 533]: Ed. pr. of fragments of a clay mould and of clay relief bowls with Homeric scenes (Pherai, Hellenistic). Inscriptions identify the persons as Theseus, Helena, and Pirithoos (1-2; the scene represents the abduction of Helena), Kyklops (3), 
Agamemnon (4-5), Glaukos (6), and Sisyphos (7). The most interesting text is found on a bowl,

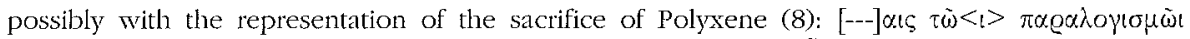

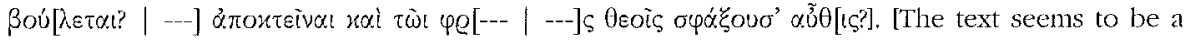
quotation from a literary text; for similar bowls from Pella $c f$. EBGR 1996, 2; SEG XLV 785]. [AC]

5) K. As'AD - J.-B.-YON, "Textes et fragments grecs de Palmyre", Syria 78 (2001), p. 153-162 [BE 2002, 464]: Ed. pr. of 17 inscriptions, mostly epitaphs., from Palmyra. We single

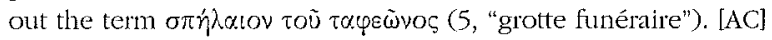

6) N. AtallaH, "Des inscriptions du nord de la Jordanie", EA 33 (2001), p. 199-208 [BE 2002, 480]: A. publishes some Greek and Safaitic inscriptions found in the northern part of modern Jordan. Among them a Roman dedicatory inscription found in 1995 in the village of Torra [undated, probably 2nd/3rd cent. AD]: A Roman veteran dedicated an unidentified object together

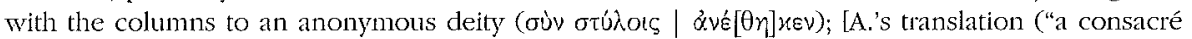
cette colonne") should be corrected accordingly]. [JM]

7) A. Avram, "Autour de quelques décrets d'istros", Pontica 33-34 (2000-2001), p. 337. 348: The cult of the Samothracian gods in Histria was attested through two references to their sanctuary (I.Histria 11 and 58: Samothrakion) and through a decree concerning the hereditary

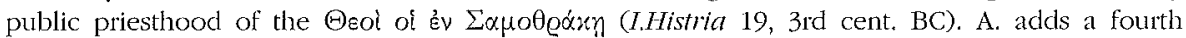
document to this evidence, a fragmentary decree (I.Histria 36, 2nd cent. BC), of which he presents a new edition. The decree honors envoys sent to Samothrake and mentions the setting up of stelae in the Samothrakion. $[\mathrm{AC}]$

8) M.W. BALDWIN BOWSKY, "A Temple of Hermes at Sybritos: On the Road from Gortyn to the Diktynnaion (Crete)", $A S A A 79$ (2001), p. 263-276: Ed. pr. of an inscription which records the construction and consecration of a sancturay (legóv) of Hermes for the well-being of

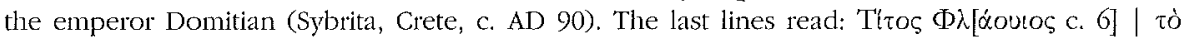

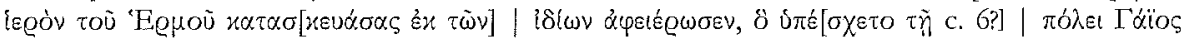
Пoutúvios [c. 13]. C. Pomponius should be identified with the proconsul of Creta et Cyrenarum T. Pomponius Gallus Didius Rufus. B. assumes that T. Flavius is the subject of all the verbs (i.e., he built at his own expenses and dedicated the sanctuary, which he had promised to the city); Flavius may have been a magistrate or a priest; [but one expects his cognomen in the lacuna; there is no space for both the cognomen and a title, and it is improbable that he had omitted the title of his office; Flavius probably did not make the dedication in an official capacityl. Why the proconsul is mentioned, is not clear, possibly as an indication of imperial authorisation for the

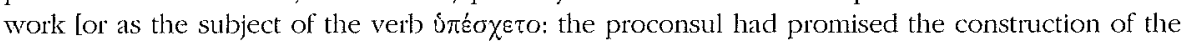
temple, but a wealthy individual in the city, somehow connected with the proconsul - as his name suggests, he may have received Roman citizenship through imperial patronage - took upon himself the financial burden]. [AC]

9) M. BALlANCE - Ch. ROUECHÉ, "Three Inscriptions from Ovacik", in M. HARRISON, Mountain and Plain. From the Lycian Coast to the Pbrygian Plateau in the Late Roman and Early Byzantine Period, edited by W. Young, Ann Arbor, 2001, p. 87-112: Among the acclamations inscribed on a stele in an ancient settlement at Ovacik (Lykia) to honor Hermaios, a brigand chaser (c. AD 280) we single out the acclamtion which praises the killing of

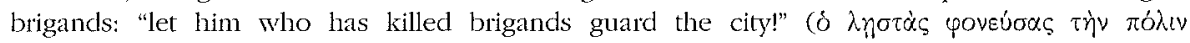

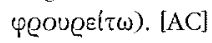

10) F. BarattF, "Le Mithreum de Sidon : certitudes et questions", Topoi 11 (2001) [2003], p. 205-227: B. discusses the iconography of the statues found in a Mithraeum in Sidon (CIMRM $\mathrm{n}^{\text {in }}$ 74-87); three of them (Mithras killing the bull, a male figure with a lion-head, a triple

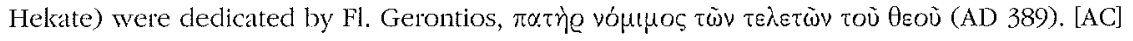

11) M.C. Barkigón, "El Más Allá en las inscripciones funerarias griegas", in A. Alonso Avila et alit (eds.), Homenaje al Profesor Montenegro. Estudios de bistoria antigua, Valladolid, 1999, p. 133-149: B. summarizes the views expressed about afterlife in funerary inscriptions, especially in funerary epigrams, and the common themes of epigrams (darkness of 


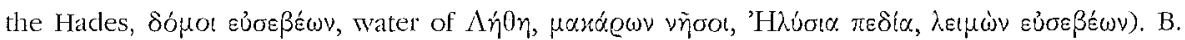
argues that the traditional pessimistic idea of the underworld coexisted with the belief that the virtuous persons enjoyed a blessed life after death. [AC]

12) A. Béus, "Esthétique musicale du péan à travers l'example des Hymnes delphiques à Apollon", in Chanter les dieux, p. 97-114 [BE 2002, 211]: After a brief discussion of the discovery of the Delphic paeans to Apollon with signs of musical notation (CWD III) [cf. infira $\mathrm{n}^{\circ}$ 621, B. endorses the view that both paeans were composed and performed during the Pythais of 128 BC [for a different view see EBGR 1999, 222 and my remarks in SEG XIIX 562]. In a detailed analysis of the aesthetic features of these compositions, B. argues that the paean of Athenaios was sung a capella by a choir of men, whereas Limenios' paean, composed by a kitharist, was interpreted by the entire synod of the technitai, i.e. by a choir of men and musicians. She urges to read the poetry of these paeans in close connection with its rythmical and melodic setting. The aim of these compositions was to demonstrate the musical excellence of the Athenian technitai, to associate the myths of Apollo with Athens, and to support the effort of the Athenian technitai to obtain the monopoly of the Delphic celebration. [AC]

13) M. BERTr, "Per una nuova editione dell'epigrafe eleusinia SEG, XXXV (1969), n. 224", Epigraphica 63 (2001), p. 252-256: B. presents an improved edition of a dedicatory inscription for Demeter and Kore (Eleusis, late 4th cent. BC; SEG XXIV 224) and discusses prosopographical questions related to the dedicants. [IM]

14) L. BEsCHI, "Cabirio di Lemno: testimonianze letterarie ed epigrafiche", $A S A A$ 74/75 (1996/97) [2000], p. 7-145 [SEG L 824-862]: B. presents a collection of the literary (p. 13-34) and epigraphic sources on the Kabeirion of Lemnos, with commentary on the information they provide on the topography, the cult practice, the origins of the cult, and the cult personnel (p. 32:

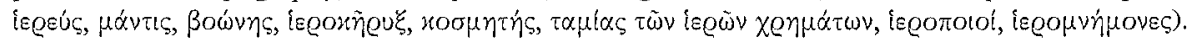
Among the new inscriptions published by $B$. we single out an honorary decree of the demos of Hephaistia (lines 2-3: $\sigma \dot{v} v \lambda \circ \gamma \circ \tau_{\bar{\omega} \nu} \mid[\tau \varepsilon] \tau \varepsilon \lambda \varepsilon \sigma \mu \varepsilon \dot{v}(\omega v)$ for a benefactor (23, 4th cent. BC), building instructions concerning building activities in the sanctuary (24 and 33 , 3rd cent. $\mathrm{BC}$ ), a fragmentary dedication to the Kabeiroi (?, 30, 3rd/2nd cent.), two fragments mentioning the office of the hieromnemon (26-27, undated), a bronze disc dedicated to the sanctuary (56, Hellenistic:

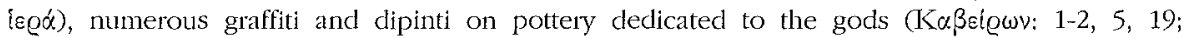

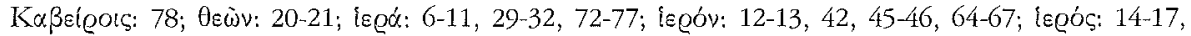
$38,105)$, and 31 manumission records written on a stele found near the Roman telesterion (25, 2nd-1st cent. BC). Two of the manumissions ( $\mathrm{n}^{\text {in }}$ xvi and $\mathrm{xx}$ ) refer to the agreements ( $\delta \mu \hat{\lambda}_{0} \gamma^{\prime}(\alpha)$ which contained the conditions of the manumission and were deposited in a sanctuary of Sarapis

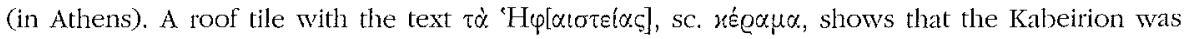
built by the city of Hephaisteia [as pointed out by M. Sז̈vE, $B E 2002$, 50]. [AC]

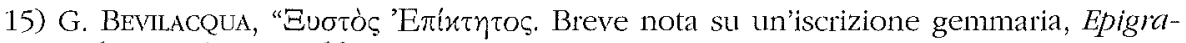
phica 63 (2001), p. 55-66: A gem in the Museum of Kassel bears a representation of a seated

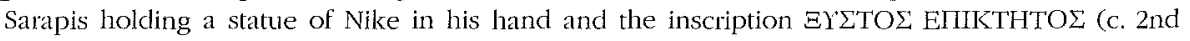

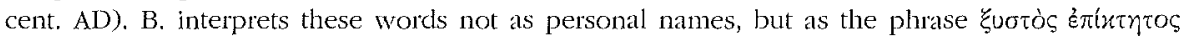
("an additionally aquired seat of an athletic club") and attributes the gem to the milieu of athletes

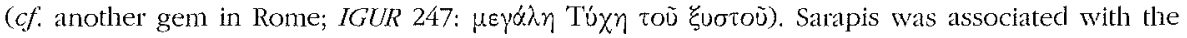
athletic club as the patron of victory and success (nikephoros). Some evidence for the devotion of athletes to the cult of Sarapis in Alexandria makes this city the most probable origin of the gem. $[\mathrm{AC}]$

16) G. Bevil.ACQUA, "Chiodi magici", ArchClass 52.2 (2001), p. 129-150: B. presents a very useful catalogue of bronze nails inscribed with voces magicae and magical charakteres (3rd-6th cent. AD; for the use of nails in magic cf. PMG VII 466; LXXVIII 5). The inscriptions consist of

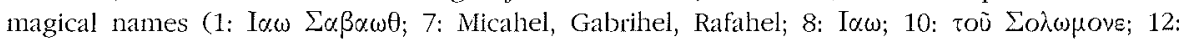
Abaraxas, Astrael, Ao, Sabao, Solomono), magical words $(3,10,13)$, a liturgical text inspired by the New Testament (6: vincit leo de tribu radix Davit Solomoni Davit filius Iesse; cf. Apoc. V, 5),

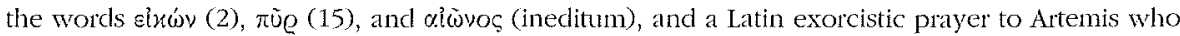


is asked to protect the fields and the livestock ( $4,4 \mathrm{~h} / 5$ th cent.); in this text Artemis is mentioned next to the Christian god and Solomon (in signu dei ef signu Salomonis et signu de domma Artemin). [AC]

17) J. Bingen, "L'inscription éphébique de Léontopolis (220 p.C.)", CE 76 (2001), p. 209-229 [BE 2002, 515, 519]: B. republishes an ephebic list from Leontopolis (SEG XI 1568, AD 220) with detailed discussion of its structure, the selection of the ephebes, and the onomastics. This list was compiled after the first celebration of an ephebic agon (agon bieros eiselaslikos Antoninianos Heleios Leonios Isantinoios). B. argues that in the list of victors the discipline is followed by the name of the victor (and not vice versa). The agon included competitions in wrestling, pankration, stadion, and diaulos in the age classes of boys and ageneioi. The

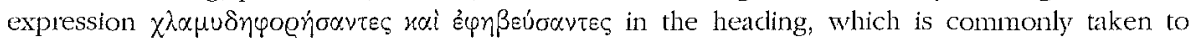
refer to a single group of young men, more probably designates two separate groups (the boys, who received the ephebic chlamys, and the ageneioi?). [AC]

18) A. Blamme, "Athenian Finance, 454-404 B.C.", Hesperia 70 (2001), p. 99-126: Based on the information provided by Thucydides and on the ample epigraphic material $B$. attempts to reconstruct the Athenian financial history from the transfer of the Delian Treasury to Athens to the end of the Peloponnesian War, studying among other issues also the role of sacred financial resources, such as the treasures of Athena and the funds of the Other Gods. [JM]

19) W. BlÜMEL, "Epigraphische Forschungen im Westen Kariens 1997", in AST 16.1, p. 403-407 [SEG XIIX 1422]: Ed. pr. of a dedication to Demeter and Kore; a priestess [of Demeter and Kore?] and a man declicated the statue (Eixu'v) of another person to the goddesses (Bargylia, $4 \mathrm{th} / 3 \mathrm{rd}$ cent.). [AC]

20) W. BLÜMEL, "Epigraphische Forschungen im Westen Kariens 1999", in AST 17.1, p. 251-253 [BE 2001, 400; SEG XIIX 1423, 1434]: Ed. pr. of an honorary inscription for T. Flavius Ptotoleon Sophanes (Mylasa, Imperial period); his fellow ephebes (of $\sigma u v \varepsilon ́ \varphi \eta$ Bor) dedicated his statue after his death (1. 5: ク̈gwos) in gratitude for his benefactions; [in lines 11-13 I

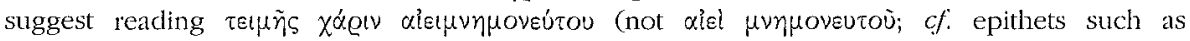

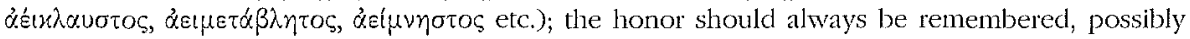
through annual rituals (e.g. the crowning of the statue)]. Ed. pr. of a dedication to Sarapis and Isis; two (or more) brothers dedicated a statue (ein $\omega v)$ of their brother (Bargylia, Hellenistic). [AC]

21) W. Blüel, "Epigraphische Forschungen im Westen Kariens 1999", in AST 18.1, p. 301-303 [BE 2002, 395]: Ed. pr. of a fragmentary document concerning the leasing of (sacred?) land (Olymos, 2nd/1st cent.), which mentions the sanctuary of Zeus Osogo [cf. I.Mylasa 801-854; EBGR 1994/95, 37 = SEG XIV 1538-1554]. [AC]

22) W. BLÜMEL, "Epigraphische Forschungen im Westen Kariens 2000", in AST 19.2, p. 157-159: An honorary inscription for a priest of Caesar and stephanephoros (CIG 2900) was found again in Alabanda. A still unpublished inscription in a private collection confims B.'s restoration of the epithet of Hekate Sossis in an inscription of Mylasa (EBGR 1994/95, $37=S E G$ XIV 910, 2nd cent. BC). [AC]

23) L. BOFFo, "Epigrafia e 'cultura' greca in Aquileia romana", in Miscellanea Gasperini I, p. 117-133: Among the elements of Greek culture attested through the epigraphic evidence of Aquileia and collected by B. one finds dedications to Apollon (Letoios Phoibos, probably associated with the local Belenus), Artemis Ephesia (by an Ephesian), Thea Epiphanes, and Zeus Thallos. B. discusses the evidence provided by Greek texts for the study of complex cultural identities in Roman Aquileia. [AC]

24) A. Bonnet, "En parcourant le Val des Muses. Remarques sur un concours musical de l'Antiquité: les Mouseia de Thespies", in Musique et Poésie, p. 53-70: Discussion of the history of the musical competitions at the Mouseia of Thespiai, the development of the agon's program - especially after the reorganisation in the late 3rd cent. BC and during the Imperial period -, its organisation, the funding, the rules for the participation, and the prizes (p. 53-61). B. 


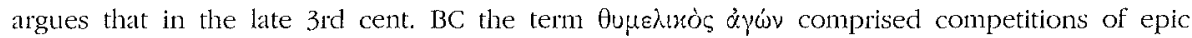
poetry, auletes, aulodos, kitharistes, and kitharodos. In the Roman period the importance of declamation, closely associated with political and civic glorification increased, at the cost of the traditional musical and poetic competitions, which were closely connected with the cult practice (p. 61-66). In an appendix (p. 67-68) B. republishes with French translation two lists of victors at the Mouseia (P. ROFsCH, Études béoliennes, Paris, 1982, p. 188f. n 32; IG VII 1762). [AC]

25) L. BrucCFSI, Hellenikòs Kolpos. Supplemento a Grecità adriatica, Rome, 2001 (Hesperia, 13): We briefly note two atticles related to religion: A discussion of Korinthian influence on the cult of Diomedes in the Adria (p. 39-43) [cf. EBGR 1999, 128], and a discussion of the cult of Aphrodite in Syrakousai (p. 89-97). [AC]

26) B. Bravo, "Deux ostraka magiques d'Olbia pontique et quelques données nouvelles sur les procédés de la magie destructive", Talanta 32-33 (2000-2001), p. 149-164: The interpretation of two ostraka from Olbia (IGDOP 97-98; SEG XXXIV 770-771) has been a matter of controversy (see $E B G R$ 1996, 153; 1998, 284). B. confirms their magical nature and regards them as defixiones. 1) With regard to the first ostrakon ( $S E G$ XXXIV 770) B. suggests a date in c. $480-440 \mathrm{BC}$ and presents the following text: 'A

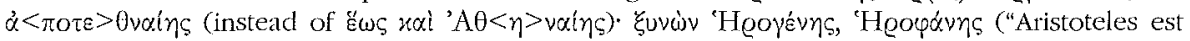
consacré à Hermès; même jusqu'à (cela): puisses-tu être mort; associés, Herogenes, Herophanes"). According to this reading, an anonymous person cursed Aristoteles and his two associates (perhaps his syndikoi in a lawsuit). The representation on the reverse is not that of Athena, but of Aristoteles and a dolphin covered by a net; this image symbolizes the power of Hermes

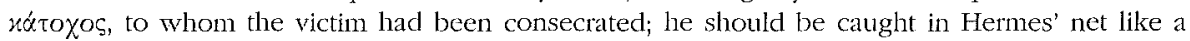
dolphin in the sea (similia similibus). B. argues that a vertical and four horizontal lines on the obverse, which form a grid, were not guidelines for the scribe, but had a magical significance ( $c f$. below). 2) The second ostrakon (SEG XXXIV 771, c. 400-350 BC?) was found covered by a layer of red ochre, on which an $X$ was engraved; this may have been a symbol of violent death. $B$. suggests reading $\Phi \alpha \varrho v \alpha \dot{\beta} \alpha \zeta \zeta$ Pharnabazos, amoureux de la beauté; je le sais d'avance: tu es mort : je suis tranquille, moi, le prophète d'Hermès"). B. accepts A. LEBbDFv's view that the prophecy of death was meant to cause Pharnabazos' death; the defigens assumed the role of a prophet of Hermes Chthonios. The drawing on this ostrakon represents the cursed person, with a ribbon bound on his head, alluding to the consecration of Pharnabazos to Hermes Chthonios. B. attributes a magical significance also to the enigmatic signs and chaotic lines next to the drawing. Finally, B. observes that two features of the two texts, i.e., the lines which frame the first ostrakon and the ochre used to bury the second one, reappear in an ostrakon with a private letter (SEG XIII $710=I G D O P 24$, c. 550-510 BC). According to B. this letter was re-used for magical purposes: a defigens used the letter, as a personal object ("object-substitut") of the cursed adversary. [One should note the difference between these early defixiones and the 'normal' defixiones with regard to the material: defixiones were normally written of lead tablets. The use of ostraka suggests that the preference for lead has nothing to do with the qualities of this metal (cf. F. GRAF, Goltesnabe und Schadenzauber. Die Magie in der griechisch-römischen Anlike, Munich, 1996, p. 119-120), but rather with its practical use: lead tablets, exactly as ostraka, were used for the writing of letters; the defixiones were letters to the powers of the underworld, and precisely as letters they were written on the material which was normally used for this purpose. It should be noted that in addition to references to defixiones written on papyrus and wax (Graf, ibid., p. 120), we now also have a defixio on stone (infira $\left.\mathrm{n}^{\circ} 71\right)$ ]. [AC]

27) L. Brody, "The Cult of Aphrodite at Aphrodisias in Caria", Kemos 14 (2001), p. $93-$ 109: B. summarizes the archaeological and epigraphic evidence on the cult of Aphrodite in Aphrodisias, discussing inter alia the history of the sanctuary, its asylia, building activities in the sanctuary, the cult image of the goddess, the cult personnel, the festivals, the role of doves as sacred animals of Aphrodite, and the dedications to her. [AC] 
28) Chr. Bruns-ÖZGan, "Tyche mit Agathos Daimon und den Horen", EA 33 (2001), p. 137-144 [BE 2002, 394]: B. publishes a small altar found near Mylasa with figures in relief on all four sides (c. $300 \mathrm{BC}$ ); inscriptions identify the represented deities. A standing woman (A) is

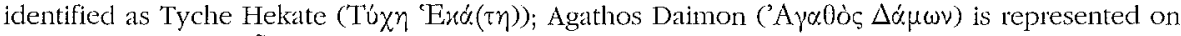
side B. Two Horai ( ${ }^{\tau} \Omega_{\varrho \alpha l}$ ) are represented on sides $C$ and $D$. The combination of Tyche with Hekate and the connection of Tyche with the Horai were hitherto unattested. [JN]

29) A. Buonopane, "Una defixionis tabella da Verona", in Miscellanea Gasperini I, p. 163-169: Ed. pr. of a lead tablet, carelessly cut from a larger lead sheet, found in a grave in Verona (late 2nd/early 3rd cent.). The text is a defixio in Latin, which consists of three names (Trophimen, Zosimen, Chariten; one observes the use of the Greek declination) followed by the formula vindictam de illis fas. "lautore della defissione intendeva porre in risalto che la vindicta nei confronti dei suoi nemici era giusta e lecita, grazie all'asseno divino, oppure, dato che talora l'espressione fas est era sentita come congiunta in vario modo a fatum, che essa era un fatto ineluttabile e cogente, a cui neppure gli dei potevano sottrarsi." [B. prefers the latter alternative; I think that the first interpretation is more plausible and places this text - with its obvious effort to justify the cursing - close to the 'prayers for justice']. [AC]

30) S. Busch, "Leider keine Göttin. Übersehene Senare aus Dion", ZPE 137 (2001), p. 297-304: B. recognizes in a Latin epitaph for a couple from Dion (An. Fp. 1998, 1200, 1st/2nd cent. AD) a metrical text and presents a new edition. A musical instrument (nabla) is represented in relief, with the explanation: sub dextram uxoris sculpum nabilium facit quia semper Wusis cupida dum uxit fitit ("he sculpted a nabla under the right arm of the wife, because she had always been devoted to the Muses, while she lived"). B. points to the existence of a cult of the Muses in Dion (agons for Zeus and the Muses) and at Pimpleia (the Pimpleides Muses) and suggests that the woman was a professional musician who performed in the cult. [AC]

31) F. CAirns, "IG XII.9 11: An Inscription of Karystos?", ZPE 134 (2001), p. 121-136: C. republishes the fragmentary inscription $I G$ XII 9, 11, arguing that it has no connection with Karystos; an attribution to a city of southern Asia Minor is much more probable. In the heading of the inscription $C$. favours the idea that the unknown honorand was a priest (or high-priest) of

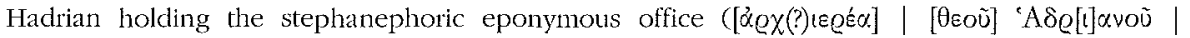

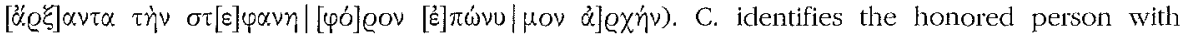
Moiragenes the Younger, who is mentioned in lines 6-7. [JM]

31 bis) D. Campanile, "Ancora sul culto imperiale in Asia", Mediterraneo Antico 4 (2001), p. 473-488: C. discusses the historical background of the establishment of the emperor cult in Asia, the differences of the Greek and Roman perspectives (cult of the living Octavian vs. cult of the deified Caesar), the role of the emperor cult for the local elites, the composition of literary works for the emperor cult, and the co-existence of different motifs: "ottimizzazione delle opportunità non escludono affato, anzi, al contrario, possono accompagnare, rivestire e dar forma a reali sentimenti di considerazione, di gratitudine, di reverenza, di espressione, insomma, di un genuino sentimento religioso" (p. 484-485) [cf. A. Chaniots, "Der Kaiserkult im Osten des römischen Reiches im Kontext der zeitgenössischen Ritualpraxis", in H. CANCIK - K. HITZL (eds.), Die Praxis der Herrscherverebrung in Rom und seinen Provinzen. Akten der Tagung in Blaubeuren vom 4, bis zum 6. April 2002, Tübingen, 2003, p. 3-28]. [AC]

32) F. CANali De Rossi, "Q. Minucio Termo e il culto di Sarapicle a Delo", Labeo 46 (2000), p. 72-82 [SEG L 726]: A letter of the generals to the epimeletes of Delos and a senatus consultum allowing Demetrios of Rhenaia to practice the cult in the sanctuary of Sarapis (I.Délos $1510 ; 5 y / l^{3}$ 664) was traditionally dated to c. $166-164$ BC. C. convincingly argues for a later date

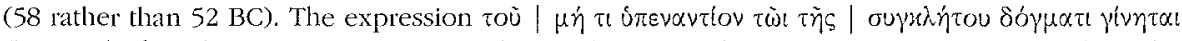
(lines 34-36) refers to a senatus consultum which introduced restrictions with regard to the Egyptian cults in Rome in 58 or 52 B.C., during the praetorship of Q. Minucius Q.f. Thermus. The earlier date (during the consulate of Gabinus and Piso) is supported by the fact that an Athenian embassy is known to have visited Rome in 58 B.C. to discuss Delian affairs (I.Délos 1511). [AC] 
33) A. CHANotis, "Ein alexandrinischer Dichter und Kreta: Mythische Vergangenheit und gegenwärtige Kultpraxis bei Kallimachos", in Ithake, p. 213-217: A study of the epigraphic evidence of Hellenistic Crete shows that references to Cretan cults and cult places in the poetry of Kallimachos (Eileithyia Inatie: fr. 524 ed. Pfeifer; Eileithyia and Artemis in Amnisos: Hymnus in Dianam 15 and 162; lamb. XII, fr. 201, 1; Thenai: Hymmus in Jovem I, 42-45; Theodaisia: Aetia II, fr. 43, 86; Britomartis and Diktynna: Hymnus in Dianam 189-205) should not be regarded as antiquarian reminiscences, but reflect contemporary cults and cult practices in Hellenistic Crete, $[\mathrm{AC}]$

34) V. CHANKowski, "Un nouveau procès délien : les comptes des naopes de Délos et la procédure athénienne au IV siècle", $B C H 125$ (2001), p. 175-193 : Ed. pr. of a new fragment of the account of the Delian naopoioi of 345 BC (I.Délos 104-24). The fragmentary text concerns the disappearance of sacred propery $(\chi \varrho \eta \dot{\eta} \alpha \tau \alpha)$ and the subsequent lawsuit in Athens, in which the naopoioi were involved. [AC]

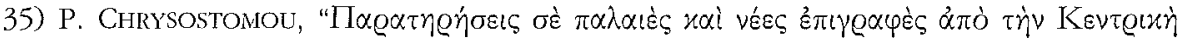

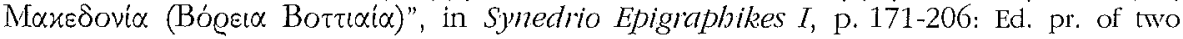

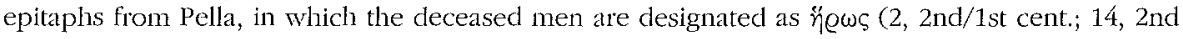
cent. BC). [AC]

36) K. Cunton, "Initiates in the Samothracian Mysteries, September 4, 100 B.C.", Chiron 31 (2001), p. 27-35 [BE 2002, 327]: Ed. pr. of a marble stele found in 1984 on the southwestern shore of Samothrace and originating from the sanctuary of the Megaloi Theoi. The inscription documents in Latin and Greek the initiation of a group of men in the Samothracian Mysteries on September 4, 100 BC. C. identifies L. Tullius M. f. Cor(nelia) mentioned in lines 4-5 as the uncle of Cicero. [JM]

37) V. COJOCARU, "Achilleus in Tyras", Tyche 15 (2000), p. 55-62 [SEG L 715 bis]: Ed. pr. of a fragment of an oinochoe with a moulded relief attached to the body; it represents Achilleus as a young man with halo (Tyras, North Shore of the Black Sea, 4th cent. BC); a retrograde stamped inscription reads 'A $\chi \imath \lambda \lambda \varepsilon \omega$. C. observes that it is not certain whether the vase was dedicated in an otherwise unknown local sanctuary or produced in Tyras to be exported to Achilles' sanctuary at Leuke (Berezan). [AC]

38) K. Colfman, "Misio at Halicarnassus", HSCPh 100 (2000), p. 487-500 [SEG L 1105]: C. discusses an important piece of evidence for gladiatorial combats in the Greek East: a slab decorated with a relief representation of women attired as gladiators (Halikarnassos, 2nd cent. $\mathrm{AD})$. According to her interpretation the two women were discharged $(\dot{\alpha} \pi \varepsilon \lambda \dot{\omega} \theta \eta \sigma \alpha \nu=$ siantes missae) because their contest was inconclusive. The objects near their feet are their uncrested helmets, which signal the outcome of the combat - i.e. that both gladiators stopped fighting, assumed the stance of surrender, and requested their missio. The relief either commemorated a sponsor's munera or decorated a gladiatorial school. The names of the two women alluded to the famous mythological fight between Achilleus and the Amazon Penthesileia. [AC]

39) T. ConSTEn, "Kibyra 2000", in AST 19.2, p. 139-146: Ed. pr. of three dedications (Kibyra, Imperial period). Two of them were made in fulfillment of vows (sưn'v) to Theoi Dikaioi and to a goddess with the epithet Karpophoros respectively (now in I.Kibyra 96 and 95). The third fragmentary dedication was addressed to the tetrarchs. [AC]

40) L. Criscuolo, "Nuove riflessioni sul monumento di Ptolemaios Agrios a Panopolis", in Miscellanea Gasperini I, p. 275-290 [BE 2002, 541]: C. discusses the fragmentary metrical inscription of Ptolemaios Agrios, in which his life and deeds are combined with a characterisation and praise of four gods: Zeus, Ares, Poseidon, and Hades (Panopolis; E. BERNAND, Inscriptions métriques de l'Ésypte gréco-romaine, Paris, 1969, $n^{\circ}$ 115; late 2nd/early 3rd cent.?). The text was written on a pilaster decorated with representations which correspond to the four deities mentioned in the poem: an eagle for Zeus, a sea creature for Poseidon, a shield for Ares, and probably a dog for Hades. Homeric verses referring to these deities (Ilias II, 412; V, 31; Odyssey' IX, 528) introduce the various sections of the biographical poem. In his critical edition, followed 
by a commentary, $C$. suggests adopting the following sequence for the sections referring to the four deities: Zeus, Hades, Ares, Poseidon. The text should be seen in a funerary context. [AC]

41) L. Criscuolo, "Filometore a Ptolemais di Cirenaica", ZPE 135 (2001), p. 264-266: C. presents a new restoration of an honorary inscription in Ptolemais (SEG XLVT 2214: B $\alpha \sigma \lambda \hat{\lambda} \in \alpha$

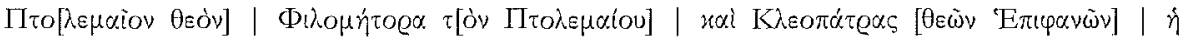
$\pi \delta[\lambda \iota s])$ and attributes the statue erected by Ptolemais not to Ptolemaios VIII $(B E 1997,712)$ but to Ptolemaios VT Philometor (c. 170-164 BC). [JM]

42) N.B. Crowther, "Resolving an Impasse: Draws, Dead Heats and Similar Decisions in Greek Athletics", Nikepboros 13 (2000), p. 125-140: C. collects references, primarily in

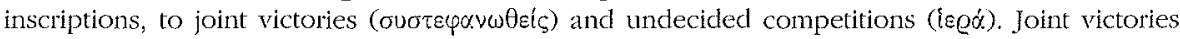
are usually attested in local agons of the Imperial period; they are hitherto unattested for the Olympic games. Both opponents were declared victors either because time had become a problem for the organisers of agons or because the opponents agreed to share the victory (and the avards). In the case of competitions, which remained undecided because both opponents withdrew or because the agon was interrupted by the trainers, the award was dedicated to the god. Such sacred victories were common in the Imperial period and attested for both local agons and for the great crown agons, such as the Olympia and the Isthmia. In some cases a single athlete received the rewards even though the contest was declared undecided (earliest attestation: $I D O$ 54); such a decision seems to have been the result of interventions by influential persons. [AC]

43) N.B. CrowTher, "Victories Without Competition in the Greek Games", Nikephoros 14 (2001), p. 29-44: C. discusses the evidence concerning victories without competition in athletic agons (usually chatacterized as $\dot{\alpha} x o v i \tau i$ and $\left.\dot{\alpha} \mu \alpha \chi_{\varepsilon}\right)$. Such victories were very prestigious, especially when they were acchieved because of the fame, the strength or the skill of an athlete. In some cases an athlete won because the opponent did not arrive on time or withdrew during the games, or because only one athlete had entered the competition. There is no evidence for complaints from the spectators who thus lost the opportunity to watch a competition. [AC]

44) E. Culasso Gastald, "L’iscrizione trilingue del Museo di Antichità di Torino (dedicante greco, ambito punico, età romana)", Epigrapbica 62 (2000), p. 11-28: C. discusses the cultural context of a trilingual (Latin, Greek, Punic) dedication to Asklepios Merres (Eshmoun) (Sangtuiaci, north of Cagliari; IG XIV 608). Kleon, a slave responsible for salt-works, dedicated an altar upon command of the god ( $x \alpha \tau \dot{\alpha} . \pi \varrho o ́ \tau \alpha \gamma \mu \alpha$; but in the Latin version: donum dedit lubens merito merente). C. suggests a date in the 1st cent. BC. [AC]

45) H. Cuvigny, "Un soldat de la cohors I Lusitanorum à Didymoi : du nouveau sur l'inscription I.Kanais 59bis", BIFAO 101 (2001), p. 153-157 [BE 2002, 528]: Ed. pr, of a graffito on a tile found in the baths of the praesidium at Didymoi in Egypt (c. AD 180-192). Vettius Crispinus, a soldier of the cohors I Lusitanorum reports: "I made the banquet for good

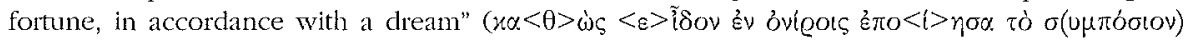
$\varepsilon \pi^{\prime} \alpha \gamma \alpha(\theta \omega)$ ). Crispinus can be identified with the scribe of a similar graffito, probably from a

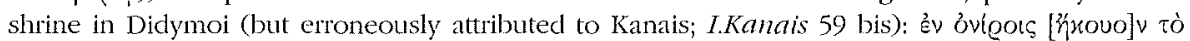

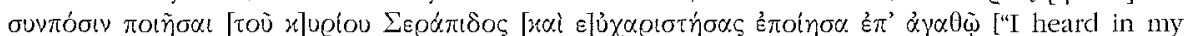
dreams that I should make the banquet for lord Sarapis; and I made it in expression of gratitude

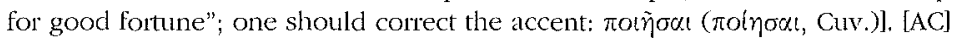

46) M. Daumas, "La représentation d'un atelier de potier du Cabirion de Thèbes sur un skyphos Béotien?", in Agatbos Daimon, p. 117-123 [SEG L 511]: D. proposes a new interpretation of an inscribed skyphos from Abai (4th cent. BC); the painted inscription reads $\Sigma\left(\beta \omega y\right.$ roגós [R. WACHTER, Non-Attic Greek Vase Inscriptions, Oxford, 2001, p. 22 n ${ }^{\circ}$ BOI 19, observes that the text is written in full Ionic script and that the name is unparalleled ( $\Sigma(\varphi \omega v ?)]$. D. associates the representation (a potter's workshop) with the mysteries of the Kabeiroi in Thebes: the scene shows the production of vases for the annual festival in the Kabeirion; a young man is flogged by a potter-priest for his indiscretion in observing this activity. $\sum i \beta \omega \nu$ may have been a young initiate. $[\mathrm{AC}]$ 


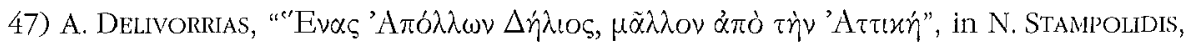

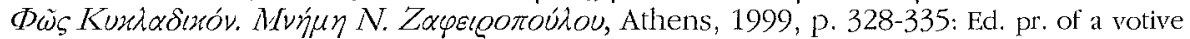
relief inscribed with the name of Apollon ['A $\pi \dot{\lambda} \lambda \lambda \omega[v$ ?t]]. It represents the god leaning on a pillar, with a bow and quiver, next to an altar and the trunk of a palm tree (Benaki Museum, c. 100 BC). The relief was probably found at Prasiai in Attika. The image of the god, represented as Apollon Delios, possibly derives from a cult statue. [AC]

48) E. DF Mrro (ed.), Agrigento I. I santuari urbani. L'area sacra tra il tempio di Zeuse porta V, Rome, 2000 [SEG L 996]: Ed. pr. of a few graffiti on vases (6th-5th cent.) found in a

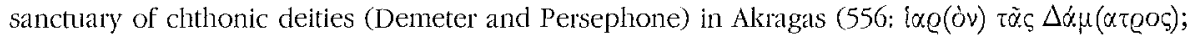

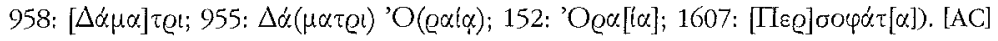

49) J. Devrekfr - H. Verreth, "New Inscriptions from Pessinous and Elsewhere (VI)", EA 33 (2001), p. 57-68 [BE 2002, 418]: Ecl. pr. of 20 inscriptions from Pessinous and its vicinity. Among them an altar with the inscription Kóouov (the dedication of Kosmos?; an altar for the unattested cult of Kosmos?; 1, c. 2nd-1st cent.). A dedication to Thea Nemesis in fulfillment of a vow was made by Metrodoros, son of Metrodoros (2, Imperial period). The theophoric name of the dedicant may be associated with the cult of Kybele. The cult of Nemesis is attested in Pessinous through another dedication found near the theater (EBGR 1997, 109). Nemesis received the dedications either in her function as goddess of competitions or in connection with the cult of Kybele. [JM]

50) G. Dietze, "Temples and Soldiers in Southern Ptolemaic Egypt. Some Epigraphic Evidence", in L. MOOREN (ed.), Politics, Administration, and Society in the Hellenistic and Roman World. Proceedings of the International Colloquium, Bertinoro 19-24 July 1997, Leuven, 2000, p. 77-89: Starting from the observation that most Greek inscriptions in Egypt are in some way related to Egyptian temples, D. studies the interaction between army and Egyptian temples in south Egypt (Kom Ombo, Philai, Devod, Elephantine) primarily during the reigns of Ptolemy VI and VIII. She plausible suggests that Greek soldiers were stationed inside or near Egyptian temples; this explains why they were actively involved in construction works in these temples (e.g., OGIS 101, 114; I.Pbilai 11). The link between the army and the Egyptian temples was also strengthened by the service of high officers as priests; e.g., Heroides was commander of the garrison in Syene, but also prophetes of Chnoum and archistolistes in the temples of Elephantine and Philai $(I . T h y . S y$. 302). Sometimes the same persons appeared with a double identity: as Greek officers in Greek texts and as Egyptian priests in Egyptian documents. The new priests of the fifth phyle, which was created by Ptolemy III, may have been leading army officers. The connection between army and temple contributed to bridging the gap between native population and Greek army. The purity of Greek culture in the foreign landed was primarily served by the gymnasium. $[\mathrm{AC}]$

51) C. Dobins-Lalou, "S.E.G. XVIII 727 : Révision et compléments", in Miscellanea Gasperini I, p. 335-346: D.-L. presents a new critical edition of a fragmentary decree of Kyrene (SEG XVIII 727, 2nd cent. BC), adding further fragments. The text seems to concern the consecra-

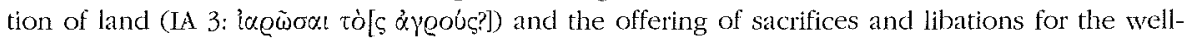
being of the Ptolemaic royal family [from the revenues?]. [AC]

52) T. DREw-BEAR, "Laodikeia Katakekaumene (Konya-Ladik) bölgesinde arastirmalar", in $A S T$ 18.1, p. 247-254: D.-B. mentions the discovery of an inscription which records the construction of a temple of Zeus by a syngeneia (Laodikeia in Lykaonia, Imperial period). [AC]

53) H. Engelmann, "Inschriften und Heiligtum", in U. Muss, Der Kosmos von Ephesos, Vienna, 2001, p. 33-44: E. presents an impressive panorama of the information provided by the Ephesian inscriptions for the cult and the sanctuary of Artemis Ephesia. He discusses Artemis'

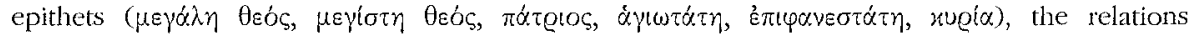
between sanctuary and city, the administration, the finances, and the property of the sanctuary,

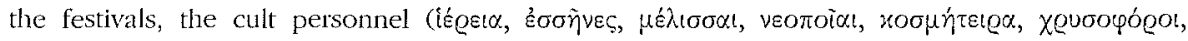




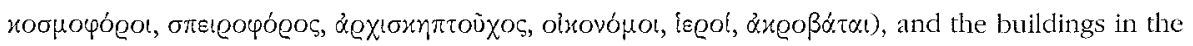
sanctuary. [AC]

54) M. EngELMANN, "Artemis und die Bewohner des Embolos. Inschriften von Ephesos Nr. 3059", Archaeologia Austriaca 84/85 (2000/2001), p. 155-157: According to D. KNIBBE a honorary inscription for a priestess of Attemis (I.Ephesos 3059), set up by the inhabitants of

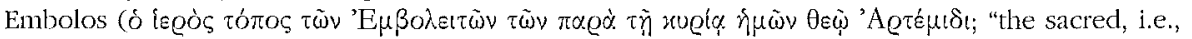
pious, district of the Embolitai, who are near our lady, the goddess Artemis"), i.e. the district between the two hills of the city of Ephesos, shows that there was an altar of Artemis in this area. E. rejects this assumption and argues that the expression $\pi \propto \varrho \dot{\alpha}$. to the official cult place of Artemis in the Bouleuterion, which was located in this district, and does not prove the existence of an altar. [AC]

55) Chr. Faraone, "A Collection of Curses against Kilns (Homeric Epigram 13.7-23)", in A. Yarbro Collins - M.M. Mitchell (eds.) Antiquity and Humanity. Essays on Ancient Religion and Philosopby. Presented to Hans Dieter Betz on His 7otb Bithday, Tübingen, 2001, p. 435-449: Based on the evidence provided by hexametrical incantations of late Classical and Hellenistic date F. suggests that lines 11-21 of the 13th Homeric Epigram are an interpolation and that the poem is comprised of no less than three different hexametrical curses against kilns. F. supposes that the source of this interpolation could have been a scholarly collection of hexametrical curses, which included a section with incantations against kilns. [JM]

56) Chr. Faraone, "The Undercutter, the Woodcutter, and Greek Demon Names Ending in -tomos (Hom. Hymn to Dem. 228-29)", AJPb 122 (2001), p. 1-10: Based on spells inscribed on amulets and defixiones or written on papyri $F$. shows that the words $i \pi$ inck $\mu v \omega v$ (1. 228) and jhotónos (1.229) in the Homeric Hymn to Demeter, in which the goddess imitates magical charms, are names of demons thought to cause pain in the gums of teething babies. F. argues that names ending in -tomos are designed to refer to intense bodily pain as the result of divine or demonical attacks. [jM]

57) M. FELL, "Neue Inschriften aus Palairos", ZPE 137 (2001), p. 125-138: Ed. pr. of a dedication of a woman to an anonymous deity (Palairos in Akarnania, late 4th cent. BC). [JM]

58) F. Ferrandini Trotsi, La donna nella società ellenistica. Testimonianze epigrafiche, Bari, 2000: The author presents a commented selection of 26 inscriptions that illustrate various aspects of the life of women from the early 4 th cent. $\mathrm{BC}$ to the 1 st cent. $\mathrm{AD}$, including the performances of women artists (poetesses, singers, musicians) in religious festivals, the service of women in religious offices (5.1-5.2 = SEG XVIII 343 and IGUR IV 1325), and their participation in athletic contests $(6.1-6.3 ; I G$ V.1, 1564a; I.Kyme 46; F.Delphes III 1, 534). In an appendix (p. 97100) F. briefly discusses the service of women in priestly offices and their privileges, and presents a list of 18 priestesses (5th-1st cent. BC). [AC]

59) J.-L. Ferrary, "Le roi Archélaos de Cappadoce à Délos", CRAI (2001), p. 799-815: F. plausibly identifies a person, whom the Athenians honored for his piety towards the sanctuary

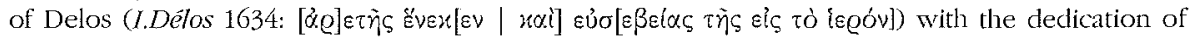
his statue to Apollon, with king Archelaos of Kappadokia (36 BC-c. AD 15). The inscription should probably be dated to the reign of Augustus. [jM]

60) K. Freitag, "Die Schiedsgerichtsbarkeit der panhellenischen Heiligtümer", in R. ALBERTz (ed.), Kult, Konflikt und Versöbnung. Beilräge zur kultischen Sühne in religiösen, sozialen und politischen Auseinandersetzungen des antiken Mittelmeerraumes, Münster 2001, p. 211-228: F. discusses the role played by Panhellenic sanctuaries, especially that of Delphi, in arbitrations between conflicting communities (Korinthos and Korkyra, Thasos and Neapolis, Kyme and Klazomenai) and in the development of norms governing behaviour during wars (esp. the Amphictyonic oath and the sacred truce). $[\mathrm{AC}]$ 
61) F. FRISONE, Leggi e regolamenti funerari nel mondo greco. I. Le fonti epigrafiche, Galatina, 2000: The first volume of F.'s thorough study on the funerary regulations of the Greek world contains a short introduction to this subject and to the public aspects of Greek funcrary rituals (p. 7-23), followed by a critical edition with detailed commentary of the relevant inscriptions from Delphi (CID I $9=I S C G$ 77), Ioulis (LSCG 97), Nisyros (IG XII 3, 87), Thasos (LSCG 64), Gortyn (I.Crel. IV 46 B, 76 B), Cuma (LSCG Suppl. 120), and Gambreion (LSAM 16). In her concluding remarks (p. 163-174) F. focuses on the aspect of impurity and on the social significance of funerals. [JM]

62) W.D. Furley - J.M. BREMER, Greek Hymns. Volume I. The Texts in Thanslation. Volume II. Greek Texts and Commentary, Tübingen, 2001: This important contribution to the study of performative ritual texts assembles the Greek hymns preserved in inscriptions and in literary sources. The introductory chapters (I, p. 1-64) treat the nature of Greek hymns, their form and their composition and present a survey of the extant remains (Homeric hymns, lyric monody, choral lyric, the hymns of Kallimachos, philosophical and allegorical hymns, magical hymns, prose hymns, the Orphic hymns). Translations and introductions to the individual texts are presented in the first volume, critical editions and commentaries in the second. In addition to hymns known from literary sources (compositions of Alkaios, Anakeon, Aristotle, Herodas, Pindar, and Sappho, hymns in tragedies and in the comdies of Aristophanes), the collection includes many hymns preserved in inscriptions: the hymn to Zeus Diktaios from Palaikastro (1.1), Aristonoos's hymn to Hestia (2.3), the paean to Apollon (2.4), Philodamos' paean to Dionysos (2.5), and the paeans of Athenaios and Limenios (2.6) in Delphi [cf. supra $\mathrm{n}^{\circ}$ 12], the 'Erythraean pacan' to Asklepios (6.1) [cf. infra $n^{\circ}$ 161], the Epidaurian hymns to the Mother of Gods (6.2) [cf. infra $\mathrm{n}^{\circ}$ 195], Pan (6.5), and Pantes Theoi (6.7), Ariphron's paean to Hygieia (6.3) and Isyllos' paean to Apollon and Asklepios in Epidauros (6.4), Sophocles' paean to Asklepios (7.3), Makedonikos' paean to Apollon and Asklepios (7.5), and the hymns to Telesphoros in Athens (7.7), and a hymnic dedication to Artemis in Paros (12.5) [see also infia ${ }^{\circ} 121$ ]. The second volume includes a list of epithets and attributes of the gods, an index of sacred places, a list of musical instruments referred to in the hymns, and an index of Greek words. [AC]

63) P.-L. Gatier, "Le site de 'Arsha Wa-Qibar", Topoi 11 (2001) [2003], p. 175-182: G. presents an improved text of an epitaph of a soldier from 'Arsha Wa-Qibar (Syria, AD 229), where a Mithras relief was found, and suggests that the cult of Mithras in this areal should be placed in the context of the presence of the Roman army. [AC]

64) Ph. Gauthier, "Les assemblées électorales et le calendrier de Samos à l'époque hellénistique", Chiron 31 (2001), p. 211-227 [BE 2002, 326]: Based on a study of inscriptions, which provicle information on the electoral assembly in Samos (espescially IG XII 6.1, 150-151, 169, and 172), G. argues that until the late 4th cent. BC the elections were held in the month Anthesterion, which was the 11th or 12th month of the year; the year must have begun on the spring equinox, as in Miletos. In the late 4th or early 3rd cent., for unknown reasons, the Samians moved the beginning of the year to the summer solstice (Metageitnion), and the elections were held in the 12th month (Kronion). [AC]

65) M. Gawlikowski, "Le Mithraeum de Haouarte (Apamène)", Topoi 11 (2001) [2003], p. 183-193: G. reports on the excavation of a Mithraeum in Haouarte (15 km north of Apameia) with interesting wall paintings; on one of them a fragmentary inscription mentioning Mithras is

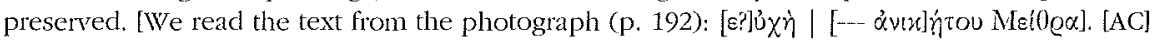

66) S. GForgotnI, "La procession chantante des Molpes de Milet", in Chanter les dieux, p. 153-171 [BE 2002, 367]: After a brief discussion of the religious and political prominence of the board of the molpoi in Miletos, G. discusses the lex sacra which contains the orgia of the molpoi (LSAM 50; Milet I.3, 133) focusing on the religious significance of the seven stations of their procession from Miletos to Didyma (lines 25-31). The procession took place in the spring, i.e., in the season in which Apollon was believed to return to his cult sites; the month of Taureon was the first month of the Milesian year. The festival of the Hebdomaia may have been celebrated in this month. The procession stopped for the first time at a shrine or statue of Hekate, where a 


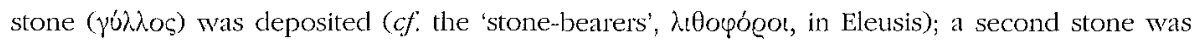
deposited at the end of the procession, in front of the gate of the sanctuary at Didyma. Hekate is known to have been worshipped in Apollon's sanctuary (Milet I.3, 129). The Dynamis, the shrine where the second stop was made, should be interpreted as a divine power; $G$. associates the

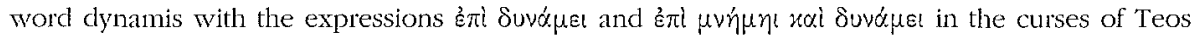
(SEG XXXI 984-985), suggesting that Memory and Power in Teos were recipients of divine honours. The third stop was made in a meadow on Mt. Akron to honor the Nymphs. The Nymphs were often closely associated with Apollon. Interestingly enough in Thasos the singing of paeans was not allowed during the sacrifice to Apollon Nymphegetes and the Nymphs (LSCG $114 \mathrm{~A})$; this shows the local character of some ritual prohibitions. The fourth stop honored Hermes $\varepsilon v \operatorname{k} \varepsilon \lambda \dot{\alpha} \delta \omega ;$ Kelados was either the name of a river or the occupant of a precinct (cf. Zeus Meilichios év Múorw in Selinous, in SEG XIII 630). Nothing is known about Phylios, for whom the fifth stop was made. Keraites, the sacred place of the sixth stop, may be an epithet of Apollon (c). Apollon Kereatas in Achaia: PAUS. VIII, 34, 5). The seventh stop was made in front of the statues of the Branchidai. In her discussion $G$. points to the importance of dance in the performance of the paeans of the molpoi and suggests that the word of $\mu \lambda \lambda \eta \eta$ í 'competition'), which is usually interpreted as a competition in singing, does not exclude a competition in dancing (p. 159-160). [JM]

67) D.W.J. GiLl, "The Decision to Build the Temple of Athena Nike (IG I3 35)", Historia 50 (2001), p. 257-278 [BE 2002, 20]: After a discussion of the archaeological evidence concerning the different phases of the sanctuary of Athena Nike on the Athenian Acropolis G. studies inscriptions in which the three-barred sigma appears $\left(I G \mathrm{I}^{3} 11,435\right)$ concluding that this letter form can appear also after $446 \mathrm{BC}$. Consequently, $I G \mathrm{I}^{3} 35$, which authorized the building of the Athena Nike temple, can be dated to 426 or $425 \mathrm{BC}$ as already proposed by H.B. Mattingly lcf. EBGR 2000, 134; but cf. M. SÈV:, BE 2002, 20]. [JM]

68) M. Giuman, "Metamorfosi di una dea: da Artemide ad Iside in un santuario di Dion", Ostraka 8 (1999) [2001], p. 427-446 [SEG L 587]: In a detailed study of the cult of Isis at Dion G. focuses on the association between Artemis Eileithyia (SEG XXXIV 629) and Isis Lochia (SEG XXXIV 622, 626/627; cf. SEG XIVII 788) and their worship as patrons of childbirth. [AC]

69) Z. GoČEva, "Les temples dans les villes et les sanctuaires thraces sur leur territoire dans la province de Thrace", in Agathos Daimon, p. 185-192: G. summarizes the epigraphic and archaeological testimonia for temples in cities and extra-urban sanctuaries in the area of the Roman province of Thrace (Philippopolis, Augusta Traiana, Hadrianopolis, Kabyle, Serdike, and Pataulia). The relevant evidence concerns the cults of Apollon Kendrisos, Artemis, Asklepios and Hygieia, Zeus and Hera (worshipped as Theoi Karistorenoi in Pautalia), Herakles, and the Thracian Rider Hero, who was worshipped with the epithets Zgedenos, Zgoulamenos, Zymedrenos, and Keilaidenos. G. argues that when Philippopolis was awarded the title of the neokoros of the imperial cult the priest of Apollo Kendrisos served as high priest. [AC]

70) R. Gordon, "Trajets de Mithra en Syrie romaine", Topoi 11 (2001) [2003], p. 77-136: In an overiew of the diffusion of the cult of Mithras in Roman Syria G. presents the text of a dedication made to Theos Hagios Asklepios by Theodotos, priest of Mithras (Sidon, AD 140/41, p. 85); it is remarkable that a priest of Mithra made a dedication to another deity, Asklepios, probably identified with Echmoun; it may be a thanks-giving dedication after cure from a clisease. [AC]

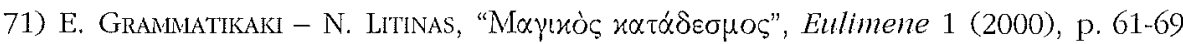
[SEG L 930]: Ed. pr. of a love defixio found in a grave in Knossos (1st cent. AD). The text is written on a splinter of green steatite, thus presenting a unique case of a defixio inscribed on stone. The first three lines contain the voces magicae HPHГYC CQBEP | ESEA PEBEPEГ |

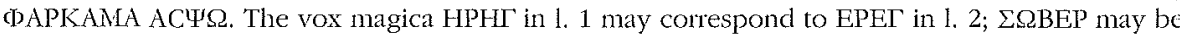
the Aramaic s"br ('separate, break'); the vox magica $\chi \omega \chi \alpha$ ('darkness') is followed by the palindromic PEBEP and $\Phi A P K A M A=\varphi \alpha Q \mu \alpha \varkappa \alpha$. Then the defigens asks a demon to separate Preimogenes and Daphne. This is the first defixio found on Crete. [AC] 
72) T. GRüLL, "Conquerors, Patriarchs and the Law of the Lord'. Interpretation of a Late Antique Jewish Epitaph", Arctos 34 (2000), p. 23-37: G. comments on the longest Latin inscription written by a Jew in the diaspora, the epitaph of Aurelius Samohil (CII 650; Katane, AD 383). Of interest is the adjuration formula in the clause concerning the protection of the grave (adiuro vos per victorias qui imperant, item adiuro vos per bonores patriarcarum, item adiuoro vos per licem quem Dominus dedit.Judeis; "I adjure you by the victories of those who command, and by the honors of the Patriarchs, and by the law which the Lord gave to the Jews"); this

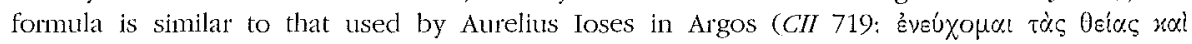

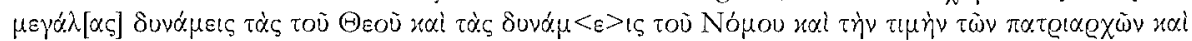

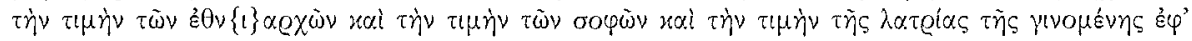

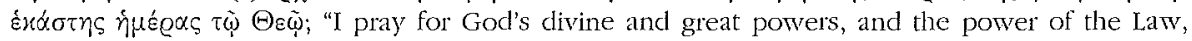
and the honor of the patriarchs, and the honor of the ethnarchs, and the honor of the wise men, and the honor of the service which is fulfilld to God day by day"). But while Ioses addressed his oath only to Jews, Samohil addressed his formula not only to Jews - through the reference to the Mosaic law, which would also appeal to Christians -, but to all the subjects of the empire, pagans, Christians, and Jews - through the reference to the victories of the emperors. [AC]

73) D. Guarisco, "Alcune epiclesi di Artemide in Attica: Ereithos, Oinaia, Horaia", Simblos 3 (2001), p. 131-161: G. discusses three Attic epithets of Artemis each one of which appears only once in inscriptions. 1) $I G \mathrm{II}^{2} 5005$ (2nd cent. AD) refers to Artemis Ereithos. G. argues that Ereithos designates Artemis as a Kourotrophos worshipped in the Athenian Iobakcheion between the Pnyx and the Areios Pagos. 2) IG $\mathrm{II}^{2} 5116$ (2nd cent. AD) attests to the existence of Artemis Oinaia in Athens at least in the Imperial period. This epitheton derives either from the Attic demos Oinoe or from wine (oinos), associating Artemis with agriculture and fertility. G. prefers the latter interpretation and suggests similarities between Artemis Oinaia and Dionysos Eleuthereus. 3) $I G I I^{2} 4632$ (4th cent. BC) is a dedication to Artemis Horaia, whom G. interprets as an Artemis Kourotrophos. According to G., all three epitheta show the importance of Artemis as a patron of agriculture and fertility in Attika. [JM]

74) W. Günther, "Spenden für Didlyma, Zu einer Stiftung aus Naukratis", in K. Geus K. Zimmermann (eds.), Punica-Libyca-Ptolemaica. Festschriff für Wemer Huß, zum. 65. Geburtstag dargebracht von Schülem, Freunden und Kollegen (Studia Phoenicia XVI), Leuven - Paris - Sterling, Virginia, 2001, p. 185-198: Ed. pr. of a fiagmentary honorary inscription from the sanctuary of Apollon at Didyma (3rd cent. BC). According to G.'s interpretation the Milesians organised a subscription in order to rebuild the temple of Apollon; the city of Naukratis reacted to this call by contributing (1. 3: $\sigma 0 \mid v \tau \varepsilon \lambda(\omega) \sigma(v)$ an unknown amount of

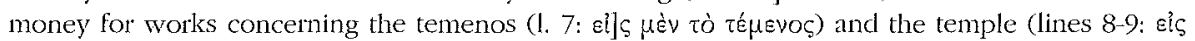

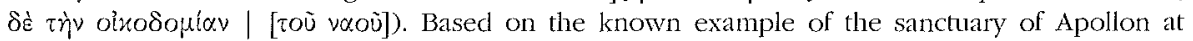
Delphi and comparable subscriptions for the rebuilding of the temple at Delphi, it seems almost certain that the Milesian subscription was not exclusively addressed to the Naukratians. [JM]

75) K. HALLof, Inscriptiones Graecae Insulanum Maris Aegaei praeter Delum. Fasciculus V. Inscriptiones Chii et Sami cum Corassiis Icariaque. Pars I. Inscriptiones Sami Insulae, Berlin, 2000 [BE 2002, 1; SEG L 810]; A brief summary of the content of this volume was presented in $E B G R 2000,69$. The first fascicule of the Samian corpus comprises 536 inscriptions: Samian and Athenian decrees, letters, lawws, catalogues, boundary stones, honorary inscriptions, and altars found in Samos. New texts are marked with an asterisk. Leges sacrae and cull regulations: A lex sacra written by the nomographoi concerns the sacrifice in the Helikonion, i.e., in the sanctuary of Poseidon Helikonios, and the duties of the epimenioi elected by the chiliasteres (168 = LSCG 122, 3rd cent. BC; cf. infra on associations). A regulation (diagraphe) proposed by the neopoiai concerns trade activities in the Heraion (169, c. $245 \mathrm{BC}$ ) [cf. EBGR 1992, 210]; the text regulates the leasing of shops, prohibitions against trading activities by slaves, soldiers, suppliants, and unemployed soldiers (?). A fragmentary lex sacra seems to concem the purchase of a priesthood; the text mentions the obligations and privileges of the priest, an altar, sacrificial animals, and the crowning of an object (the altar?, $* 170,2$ nd/1st cent. BC). The protection of the sacred land of Hera is the subject of another fragmentary lex sacra, which 
forbids the cutting of trees, the use of water, the use of the land for pasture or cultivation, and the destruction of boundary stones $(171,2$ nd cent. AD). A sacrificial regulation $(260=$ LSCG Suppl. 80, c. $350 \mathrm{BC}$ ) demands that those who sacrificed in the sanctuary should make food

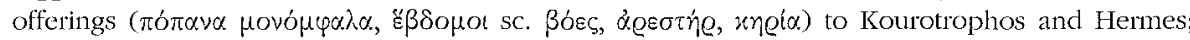
Artemis and Apollon are mentioned in a fragmentary context; it is not clear who the recipient of a

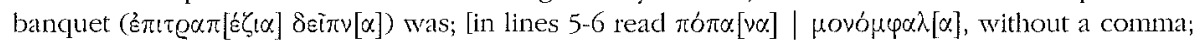
for these sacrificial cakes see $E B G R$ 1994/95, 194. The significance of number seven (1. 7:

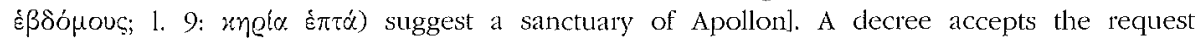
(ixerngl $\alpha$ ) of the priest of Isis to collect money for the goddess ( a yeleatv; $3=$ LSCG Suppl. 123, 3rd cent. BC). A fragmentary decree pertaining to the Syria Theos

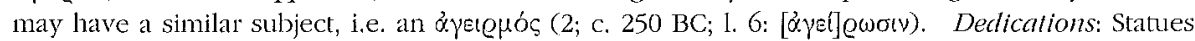
of local and foreign benefactors were dedicated to various gods, usually in the Heraion; this applies also to private dedications for family members and friends. The dedications are addressed to Hera $(* 284,285-287, * 288,289,291-293,295-298,301-303,309,317-320,322,327-328,336-342$, 347, 349-351, 354, 357, 359-364, 367-369, 372, 376, 379-380, 384, 389-394, 396, 398, 420, 431-433, 446-449, 451-452, *453, 456, 461-462, 465, 469,*472-473), Dea Roma and Augustus (294, *366, $373,404-405, * 434-435, * 440)$, the gods (471), and the Theoi Soteres, i.e. the Ptolemies (282; in the precinct dedicated to the cult of the Ptolemies). The dedications made in the Heraion were one of the subjects treated by the local historian Leon, whose statue was erected in the Heraion

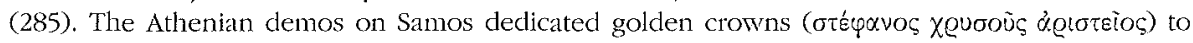
Apollon in Delphi (263-265, c. 340-330 BC).

Sanchuaries: A decree concerns a subscription for the restoration of the $\mu \dot{\varepsilon} \gamma \alpha \varsigma$ $\nu \alpha o \varsigma^{\prime}$, i.e., the Heraion (1, c. 285 BC). One of the most interesting texts for the dedicatory practices in the Heraion is the long inventory of $346 \mathrm{BC}(261)$. A very fragmentary text, which mentions a priest, sacrifices (?), and an altar, seems to deal with the leasing of a public estate (5, 2nd cent. BC). The

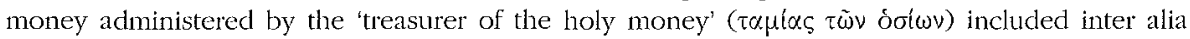
fines [paid to Hera] $(11,1.58 \mathrm{f}$., mid-3rd cent. BC). A fragmentary letter of Ptolemy III suggests measures for the treatment of slaves who sought asylum in the Heraion $(156$, c. $245 / 4 \mathrm{BC}$ ) [on this text $c f$. A. Chaniotis, "Conflicting Authorities: Greek Asylia between Secular and Divine Law in the Classical and Hellenistic Poleis", Kernos 9 (1996), p. 81]. An honorary inscription for a

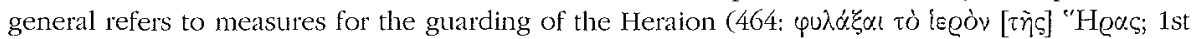
cent. BC). Several persons were honored for their piety torvards Hera, i.e. for services to her

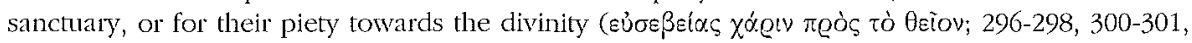
$309,317,320,328,357,359,362,367-368,379,384-385,390,431-433)$. A fragmentary decision of the Roman consuls of AD 23, upon a request of envoys from Kos and Samos, concerns the asylia of the sanctuary of Asklepios in Kos and undetermined privileges of the Heraion of Samos (163, AD 23; note the word $\delta \varepsilon เ \sigma\left(\delta \alpha \mu o^{\prime} \alpha\right.$ in I. 13). A fragmenatary imperial edict (?) refers to financial privileges of the Heraion $(* 165,1$ st cent. AD). The finances of the Heraion are also connected with the Samian law concerning free grain distribution to the citizens (172, c. $250 \mathrm{BC}$ ) [c]. EBGR

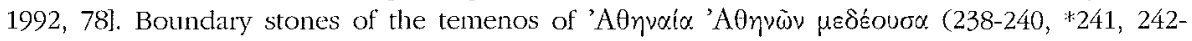
244), Ion (245-246), the Athenian eponymous heroes (247-250, *251), and Artemis (266) belong to the period of the Athenian cleruchy (second half of the 5 th cent. BC). A man was honoured by the Athenians for denouncing a man and a woman (sacred slaves?) who had stolen sacred property $(252$, c. $350 \mathrm{BC})$. A fragmentary decree of the tribe Pandionis from the period of the Athenian clenuchy concerns the repayment of debts and interest to the sanctuary of the hero Pandion; the custom prescribed that the interest should be used for sacrifices in honor of Pandion and the other gods $(255,320 / 19 \mathrm{BC}$ ). Cn. Domitius was honored for his benefactions on behalf of the sanctuary of Artemis Tauropolos on Ikaria (351).

Festivals: A fragmentary decree concerns a festival ( $\pi$ avryúgatc) for Ptolemy III and Berenike (4; c. 243-221). Honors were announced at the Dionysia $(8,56,95,150-154,156,253)$. An sun $n$ eqlo. is mentioned in a fragmentary honorary decree for an agoranomos (13 1.32). A series of agonistic inscriptions provide the names of the winners at the Heraia $(173, * 174, * 175$, 2nd/1st cent. BC), the Dionysia (176-178, 3rd-2nd cent. BC), and the agons of the gymnasium (179-183, *184, 2nd cent. $\mathrm{BC}$ ). A list of magistrates mentions the exetastai, who were in office at the time of the first 


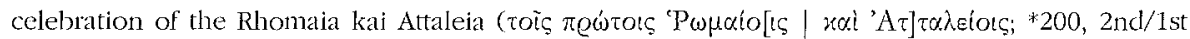
cent. BC); it is not certain whether the Rhomaia and the Attaleia were celebarted separately; [the wording suggests a joint celebration; since this was the first celebration of the agon, a date during or shortly after the reign of Attalos II is probable; a date in the 1st cent. BC should be excludedl]. Other local agons mentioned in inscriptions are the Sebasta Kaisareia (295), Megala Sebasta Heraia (312), Heraia (342), and the Lysandreia (334). A boy is honored for winning the wrestling

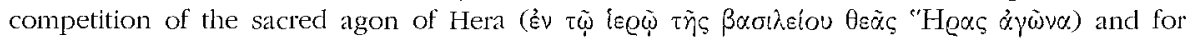

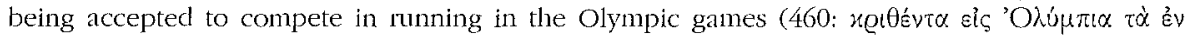

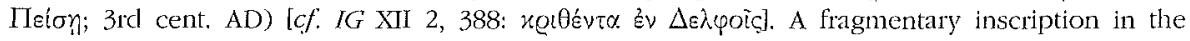
Heraion lists the Samian boy winners in agons, who had received crowns from an anonymous benefactor (290,2nd/1st cent.); only the name of the Rhodian Helieia and an anonymous agon in Seleukeia are preserved on the stone. Other agonistic inscriptions refer to victories in the Olympic games (336), the Isthmia $(338,340)$, the Kaisareia in Korinthos (339-340), the Pythia (341), and the Rhomaia in Miletos (342). The agon of Artemis Kindyas is mentioned in a decree of Bargylia

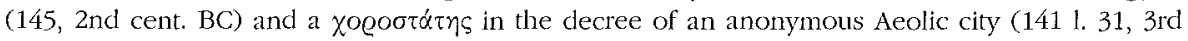
cent. BC). Cults and rihuals: Several altars attest the cults of Apollon (*529, *531), Apollon Nymphegetes (528), Apollon Nymphegetes and the Nymphs (527), Dionysios Geron (535), Zeus and Hera $(530, * 533)$, Zeus Keraunios (532,*534: Exxagtotñetov), and the personification of Tetartaios, i.e. fever (530). The agoranomos Aristomenes decorated the agoranomion with statues

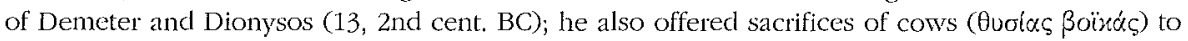

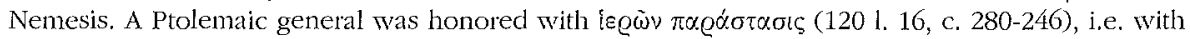
the placing at his disposal of a sacrifical animal at public expenses [for this honor see EBGR 1999,

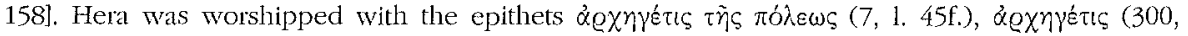
$305,330)$, and $\beta \alpha \sigma i \lambda \in 10 \varsigma$ $\theta \varepsilon \alpha{ }^{\prime \prime} \mathrm{H} \alpha .(332,460)$. In an honorary epigram for Krates, Eros is

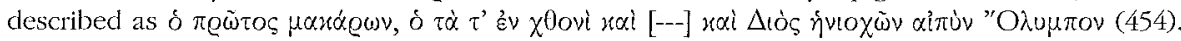
Dionysos (Bakchos) is mentioned in a fragmentary epigram (476, Hellenistic); a building inscription concerns his temple (483).

Hellenistic ruler cull: An agon in honor of 'the kings' (probably Philippos Arrhidaios and Alexander IV) is mentioned in a decree (42). An honorary decree refers to the establishment of a festival in honor of Antigonos Monophthalmos and Demetrios Poliorketes after their victory in

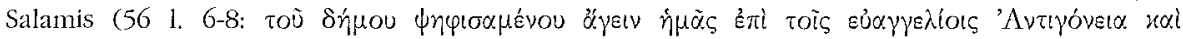
$\Delta \eta \mu \eta \tau$ lel $^{\prime} ; 306$ BC). A decree for judges from Kos mentions a temenos for queen Phila (probably the wife of Demetrios Poliorketes); a stele with the decree was to be dedicated in her

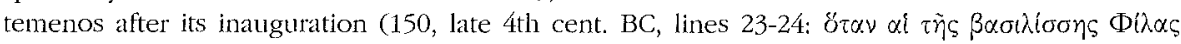

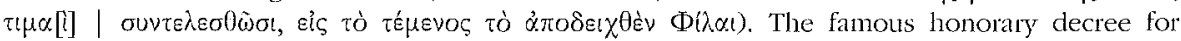
Boulagoras (11, after $243 / 2 \mathrm{BC}$ ) records his contribution to the theoria sent by the Samians to Ptolemy III and Berenike and to the sacrifices offered in Alexandria. The precinct dedicated to the cult of the Ptolemies (Theoi Soteres) is mentioned in $n^{\circ}$ 282. An altar for Arsinoe Philadelphos attests her cult (496). A list of winners at the agons of the gymnasium was dedicated to Ptolemaios (V?), Hermes and Herakles, and thus attests the ruler cult in the gymnasium (179; c. 200). Emperor cull: A clecree describes the sacrifice offered to the gods of the city and the land

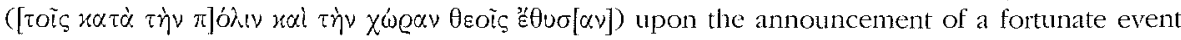

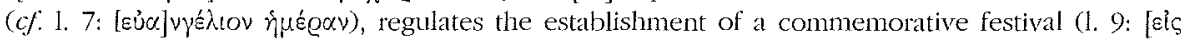

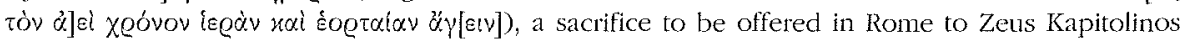
and other gods (1. 39f.), and the oath to be given by the Samians to Augustus ( $7=$ IGR IV $996+$ add; $5 \mathrm{BC}$ ); the ephebes were to go in procession to the temple of Thea Rhome and the Sebastos every year (1. 27-30); a fragment of the oath is preserved in $n^{\circ} 8$. The emperor cult is also attested through a series of altars for Augustus (497, 499), Agrippa Postumus (498), Tiberius (499), Vespasianus (501), Hadrian Zeus Olympios Epiphanes Soter and Ktistes (503-505, *506, $507, * 508-514,515-516, * 517-521,522, * 523-526$ ), and two anonymous emperors or members of the imperial family $(* 500, * 502$ ). [In 499 a and b perhaps we should delete the comma before the

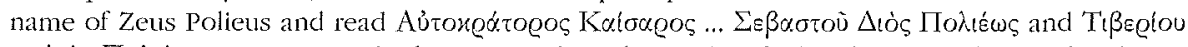

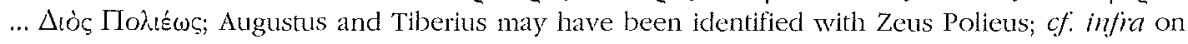
the identification of Hadrian with Zeus]. Dnusilla was honored as Nea Charis (411). The personnel 
for the emperor cult included a priest of Augustus, Cailis Caesar and Marcus Agrippa and neopoiai of the Sebastos ( 7 lines 51-55), high priest of the civic emperor cult $(310,326,331,333$, *477), and demiourgoi (324). An agonothetes dedicated stoai to Dea Roma and Augustus (484). Other dedications are addressed to Hadrian (486), and an anonymous emperor (487).

Cull officials: The neopoiai of the Heraion are often mentioned $(7,9,120,156,168-169,195-197$, $* 198,312,438,448,452,460,465)$, and lists with their names were regularly set up in the Heraion (185-198, 2nd cent. BC). In one of them the neopoiai commemorated the fact that dedications were restored to Hera during their term of office (187); these dedications were statues taken by Marc Antony and restored by Octavian (20/19 BC?; cf. STRABO, XIV, 1, 14 [C637]). Other officials included the tamias ton hosion (129), the agonothetai $(11,56,129,150,152-154,156,173,175$,

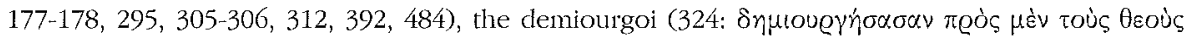
xai $\sum \varepsilon \beta \alpha \sigma \tau o \dot{s} \varsigma \varepsilon \dot{\sigma \varepsilon} \beta \dot{\omega} \varsigma$ ), the hierokeryx (150), the hierourgoi (463), the priest of Hera $(331,333)$, the priestess of Hera (327-332), and the priestess of Hera and Iulia Sebaste (sc. Livia; 330). We also mention L. Vipsanius Aeolio, exegetes of the Eumolpids in Athens, who was honored in Samos (307).

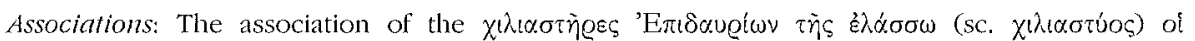

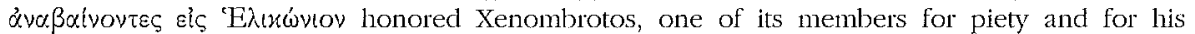
benefactions; this text also refers to mystai and a synodos $(132$, 2nd cent. BC; cf. infia, on funerary practices). Responsible for the sacrifice were the elected epimenioi $(168,3 r d$ cent. BC); the association honored its benefactors with the dedication of their statues in the Heraion (466,

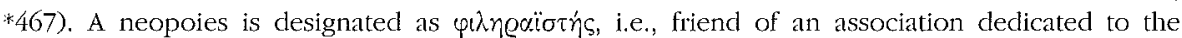
worship of Hera (195, AD 84). Curses: A decree of Antiocheia on the Maeander (6, after 167 BC) states that any person who should undertake anything against the decree and a treaty with an

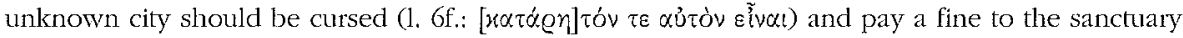

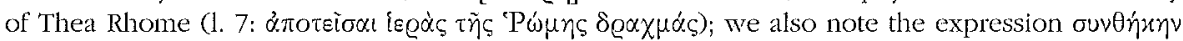
$x \alpha \theta$ te@ów (1. 4). Funeray practices: Xenombrotos, member of an association 'of those who ascend the Helikonion', had his own heroion built and made arangements for the offering of a

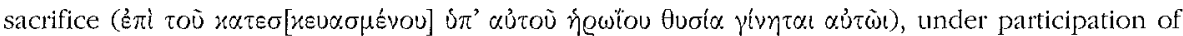

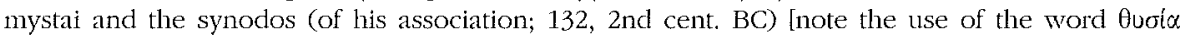
and not Évartouós, despite the funerary context]. Varia: A list of the months of the Egyptian calendar $(218,3$ rd cent. BC) is probably connected with the Ptolemaic garisson in Samos. [AC]

76) K. HaLlof et al., Inscriptiones Graeciae Septentrionalis voluminis VII et VIII non comprebensae consilio et auctoritate Academiae Scientiarum Berolinensis et Brandenburgensis editae. Pars I. Inscriptiones Pbocidis, Locridis, Aetoliae, Acannaniae, Insularum Maris Ionii editio altera. Fasciclus IV. Inscriptiones Insularum Maris Ioinii. Schedis usus quas condidit Guentherus KLAFFENBACH auxitque Daniel STRAuCH adiuvante Mathias LAwO edidit Klaus HaLLOF. Titulos Ithacenses retractavit John M. FOSSEY, Berlin 2001: The new volume of Inscriptiones Graecae $\left[I G \mathrm{LX} 1^{2}\right.$ 4] comprises the inscriptions of Kokryra (786-1230, including Korkyraean decrees and dedications found in other sites and inscriptions of other provenance preserved in the Museum of Korkyra), Leukas (12311477), Kephallenia (1478-1585), Ithaka (1586-1729), and Zakynthos (1730-1779). New texts are marked with an asterisk.

Korkyra: Dedications: Many early dedications ( 5 th cent. BC) were found in the area of the temple of Apollon Kerkyraios (822-824, *825, 826-827, *828, 829-832,*833); the god is named in many of them (Apollon Korkyraios: 822-823, 826; Apollon: 824, *825?, *828?, 829). Three vases were found near the temple of Artemis (834, *835-836, 6th-5th cent); one of them possibly refers to the goddess with the attribute $\alpha \gamma \gamma \alpha \dot{\alpha}\left({ }^{*} 836\right)$. Several dedications were made by magistrates, to Artemis (837, 4 th cent. BC) and the gods (838-842, 3rd cent. BC-2nd cent. AD). Another major group of dedications in Greek (844-847) and Latin (842-843) were found in the sanctuary of Zeus Kassios (1st cent. BC-2nd cent. AD). Two metrical dedications were addressed to Zeus as patron of seafaring. The first dedicatory epigram is an interesting piece of evidence for 'negotiations' between the declicant and the divinity (844, 1st/2nd cent. AD); after Barbaros, a seaman, had dedicated to Zeus the image of a ship (placed on a column), he was blessed by the god with 


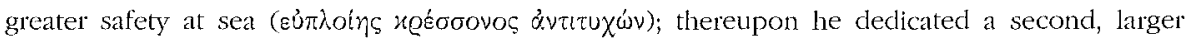
image of a ship and promised to dedicate a third one, made entirely of gold, should the god also

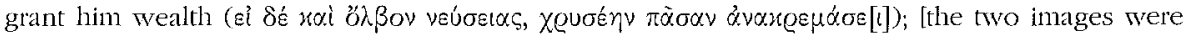
possibly made of stone or clay and were only gilded; the next one should be of solid gold; we note the verb $\alpha v^{\prime} x \rho \varepsilon \mu \alpha \omega$ ('to suspend, to hang') which refers to the practice of hanging small $\mathrm{ex}-$ votos (especially clay and metal plaques) on trees or on the walls of shrines; cf. infira $n^{\circ} 146$ ).

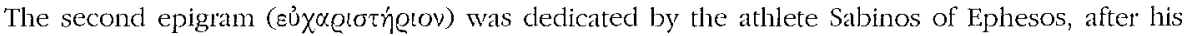
ship had safely returned to Ephesos $(845,2$ nd cent. AD). A third epigram, in fulfillment of a vow ([E] $\left.03[\xi] \alpha \varepsilon^{\prime} \nu \eta\right)$, is very fragmentary (*846, 2nd cent. AD). Another dedicatory inscription is written on a bronze plaque, which was attached to the dedication $(847,3 \mathrm{rd}$ cent. AD). Honorary statues of benefactors, members of the imperial house, and private persons were dedicated to the gods, i.e., in a sanctuary $(802,804-805,808,810,815,821,2$ nd $\mathrm{BC}-\mathrm{AD})$; the statue of $\mathrm{M}$. Cale. Bibulus was dedicated to Hermes and Herakles, i.e. in the gymnasium (806, 2nd cent. AD). Other dedications were made to Aphrodite (859-860, Imperial period), Artemis (852, 3rd cent. BC), Hermes and Herakles (854, 3rd/2nd cent.), Hygieia (851, 4th cent. BC), Pantes Theoi (853, 3rd

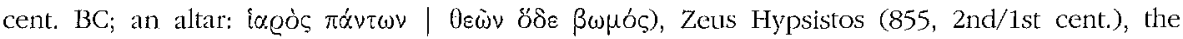
Egyptian deities (Sarapis and Isis, 857, Imperial period), and anonymous deities (848-850, 6th-5th cent.; 858 and 861, Imperial period). Several dedications were made in fulfillment of vows ( $\varepsilon \dot{\chi} \chi \alpha{ }^{2} v$ :

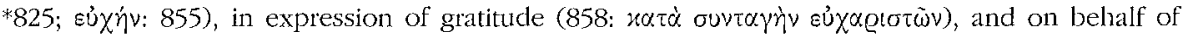

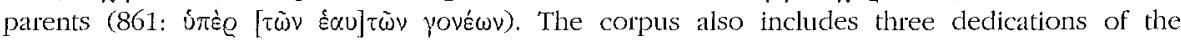
Korkyraeans to Apollon in Delphi (1198-1200). Festivals and agons: A long document (146 lines) concerns a private donation which aimed at reviving the theatrical performances at the Dionysia of Korkyra (798, 2nd cent. BC) [for a summary see EBGR 1996, 208]. We also note the grave stone of a iegoveiuns (1010,1st/2nd cent.). Sanctuaries: A fragment of accounts concerning building works probably refers to constructions in the sanctuary of Asklepios (793, 3rd cent. BC; 1.4 and

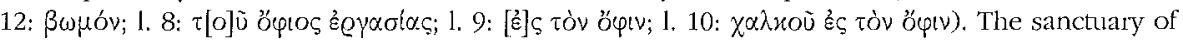
Asklepios was the site where a public document was set up (794, 2nd cent. BC). There are four boundary stones of sanctuaries: of a goddess with the epithet Akria (Hera?, 862, 5th cent. BC), Apollon Pythios (863, 5th cent. BC), the Dioskouroi (883, 4 th cent. BC), and an anonymous deity (864, undated: öeos ígoú zal boiou). The Korkyraean decrees found in other sites include the decrees conceming the asylia of the sanctuaries of Artemis Leukophryene in Magnesia on the Maeander (1196 = I.Magnesia 44) and of Asklepios in Kos (1197 = SEG XII 377). Sacred personnel: We note references to a priestess (803), an agonothetes (805), and the hieropoioi (794). Associations: The priest of an association made a donation after the end of his term (856,

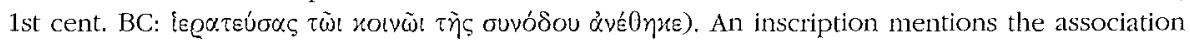

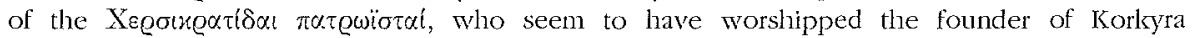
Chersiknates $(1140,2$ nd cent. BC). A fragmentary list of names includes the names of personnel

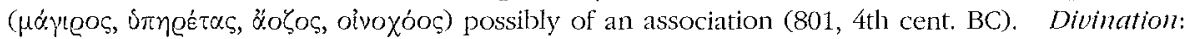
Oracular enquires of Korkyra were found in Dodona (1201-1203). Magic: In a defixio a person binds the mind and the tongue of an adversary, his witnesses, and other persons (877, 3rd cent. BC). Funerary practices: A decree concerns the heroic cult (1. 8: is (admiral?) who died in a battle (787, 3rd cent. BC). A funerary epigram alludes to the practice of

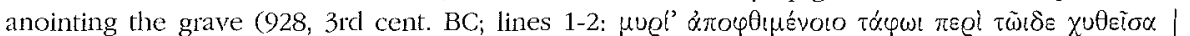

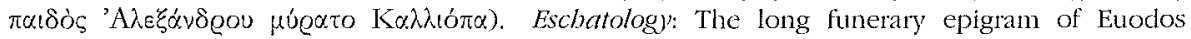

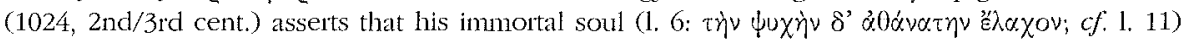

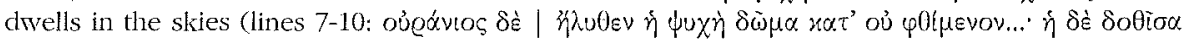

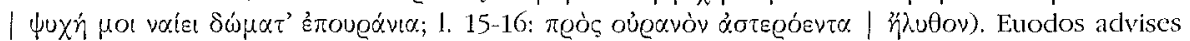
the mortals to do something good for their soul, not neglecting, however, to offer consolation to

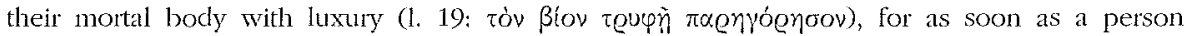
descends to the source of Lethe, he will not find in the netherworld what he had known from

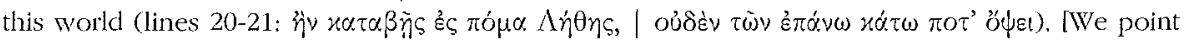

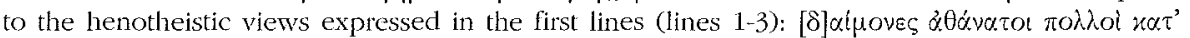

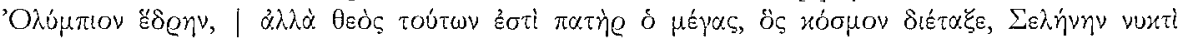

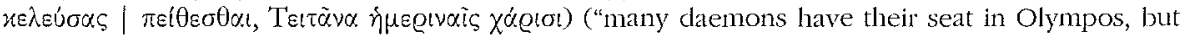
their god is the great father, who has ordered the world and has commanded the Moon to follow 
the night and the Titan (sc. the Sun) to follow the grace of the day")]. In another epigram Death

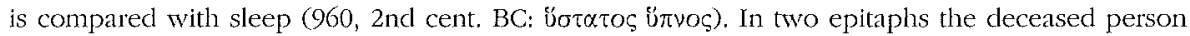

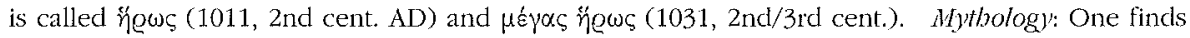
frequent allusions to the Homeric references to the island of the Phaeacians: two men had the

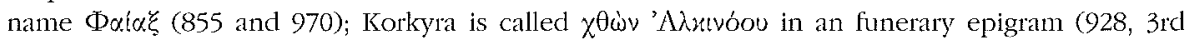
cent. BC) and Navoílou rókı in another (970, 2nd/1st cent. BC). Earty Christianity: The bishop Jovianus (5th cent.) underlines in the building inscription of a church that he had destroyed the

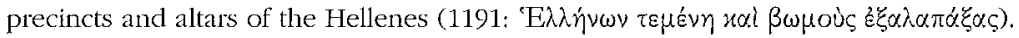

Leukas: Dedications: to Athena (1237, 6th cent. BC), Herakles (1239, 3rd cent. BC), Thetis (1238, 4 th/3rd cent.; ( $\alpha \varrho o$ s), Zeus Naios in Dodona (1476, 3rd cent. BC), and the heros Alkyniatas (1240, Imperial period). Sanctuaries: A fragmentary delimitation mentions a street leading to a sanctu-

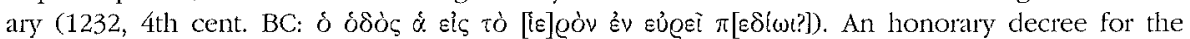
sculptor Damophon (found in Messene, ca. 200-190 BC) praises him for not accepting his honorarium for repairing the statue of Aphrodite Limenarchis; Damophon's statue was to be erected in the sanctuary and he was allowed to offer a sacrifice in the prytaneion on the common hearth (1475). A new Leukadian decree concerns the asylia of the sanctuary of Asklepios in Kos $(* 1474)$.

Kephallenia (Kranion: 1478-1492; Pale: 1493-1496; Pronnoi: 1497-1512; Same: 1513-1565; unknown provenance: 1566-1574): Dedications: to Demeter and Kore (1478, 2nd/1st cent.), the Dioskouroi $(1566$, c. $550 \mathrm{BC}$; a bronze disc by a victorious athlete), anonymous deities $(* 1481$, *1567, 5th-4th cent.), and Zeus Naios in Dodona (1584). We point to the rare formulation

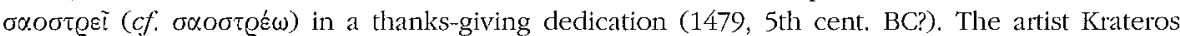
and his son made the mosaic representation of an altar, a bull, a ram, and a boar (the sacrificial animals of the trittoia) and dedicated it to Athena, the Muses, the Tychai, Apollon, and Hermes (1497, 3rd cent. AD); the same Krateros also made and mosaic representation of Envy (Phthonos, 1498). Sanctuaries: A decree of Same concerns the asylia of Artemis Leukophryene in Magnesia on the Maeander (1582). Sacred persomnel: A reference to a high priestess of the emperor cult (1495, 3rd cent. AD). Funerary practices: A man adjures by the name of Augustus (Evopxio $\sigma o t \tau o \dot{ } \mid \vee \sum \varepsilon \beta \dot{\alpha} \sigma \sigma \tau i o v$ box $\{\mathrm{I}\}$ ov) not to open the sarcophagus of Olympias; violators should be

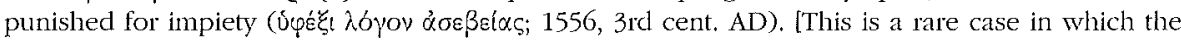
appeal to the gods for the protection of the grave is substituted by a reference to the genius Augusti; $c$ f. supra $\left.\mathrm{n}^{\circ} 72\right]$.

Ithaka: Leges sacrae: A lex sacra concerning a sacred percinct of Artemis obliges the occupant of

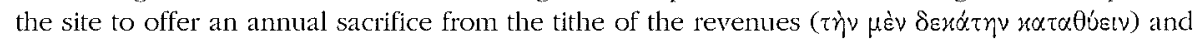
to use the rest for the restoration of the temple; violators of the regulations would be punished by

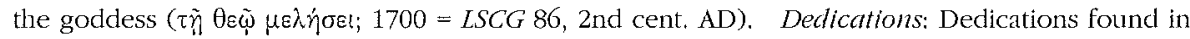
the Polis cave are addressed to Athena Polias and Hera Teleia (1614, c. 550 BC; by soldiers, peripoloi) and the Nymphs (1616-1619, 3rd/2nd cent.; vases); a Roman unguentarius commemorated his visit to this cave on a jar $(1620,35$ BC: bic fitit). A terracotta plaque found in the "cave of Odysseus' was dedicated to Odysseus in fulfillment of a vow $(1615$, 1st cent. BC). Seven fragments of vases in a cave at Vathi bear dedicatory inscriptions to the Nymphs (*1708-1712, Hellenistic). A dedication to Hermes was found in the site 'School of Homer' (1626, Hellenistic;

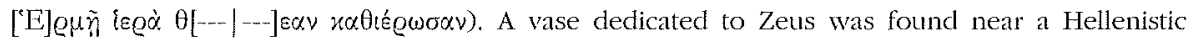
tower on Mt. Aetos (1686, Hellenistic). Two other dedications were made to anonymous deities

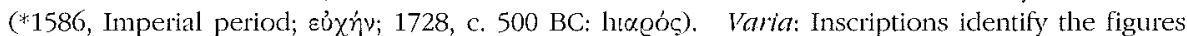
on an archaic Korinthian kotyle as the Muses and Apollon (1681, c. 600-575). A decree of Ithaka concerns the asylia of Artemis Leukophryene in Magnesia on the Maeander (1729).

Zakymthos: Dedications: A dedication to a goddess with the epithet (?) Preinatis was made in fulfillment of a vow $(1730,2 n d / 1 s t$ cent.). Agathon, a descendant of Kassandra, made a

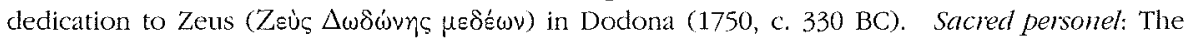
statue of Klenippa, who had served as theokolos of Artemis Opitais, was erected by her parents (1731, 2nd cent. BC). Festivals and agons: The Zakynthians dedicated a statue of Polyxenos, winner in wrestling in the age class of boys, to Zeus in Olympia (1749, 1st cent. AD). [AC] 
77) K. Hallof - H.J. Kienast, "Aus der Arbeit der "Inscriptiones Graecae" IX. Zwei Monumente aus dem Heraion von Samos", Chiron 31 (2001), p. 277-289 [BE 2002, 325; 2003, 608]: Three new fragments of an inscription of the period of the Tetrarchy in the Heraion of Samos (IGR IV 884) allow H.-K. to interpret this inscription as part of a monument dedicated by the city of Samos to Hera and the Augusti and Caesares between AD 307 and 311; according to their reconstruction the inscription stood on one of the antae of the peripteros. A new fragment of IG XII 6.1, 462 shows that the honorary monument for the trierarch Dionysios, son of Metrodoros, was dedicated to Hera in c. $250 \mathrm{BC}$. [JM]

78) C. HigBIE, "Homeric Athena in the Chronicle of Lindos", in S. Dfacy - A. VILLING (eds.) Athena in the Classical World, Leiden - Boston - Cologne, 2001, p. 105-125: H. discusses in detail the "Lindian Chronicle" (I.Lindos 2, 99 BC). Hagesitimos proposed the compilation of an inventory of the older votives in the sanctuary of Athena in Lindos and of the epiphanies of the goddess. $\mathrm{H}$. argues that the list of dedications included only those donors and votives that would enhance the claim that the sanchiary of Athena was most ancient and honorable. In its last section the inscription narrates the three epiphanies of Athena. H. proposes to understand the Lindian Chronicle as in part a dedication and in part a proclamation [see now also ead., The Lindian Chronicle and the Greek Understanding of their Past, Oxford, 2003]. [JM]

79) J. Horden, "A Fragment of Choral Lyric (P. Oxy. 674)", ZPE 134 (2001), p. 13-14: References to Delphi (1. 5), Parnassos (1. 6), and Apollon (1. 9) in P.Oxy. 674 (early 1st cent. AD) suggest a paean. $H$. suspects that a significant Delphic event is narrated in this lyric fragment, perhaps the killing of Python and the establishment of Apollon's cult at Delphi. [JM]

80) B. IpLIKçıŏLu, "Doğu ve kuzeydoğu Lykia-güneybati Pisidia epigrafilk-tarihi cografi yüzey arastirmalari projesi 2000 yili çalismalari", in $A S T$ 19.2, p. 127-132: I. reports the discovery of inscriptions in various sites in Lykia and Pisidia. A group of seven dedications to Ares (Megas Ares Epekoos: 13-14; Megas Ares: 17; Ares: 15, 18-19) in fulfillment of vows (Eủxív) were found in Havuzönüdami (13-19, Imperial period); two of them were made by groups of

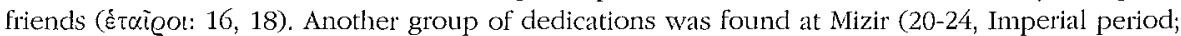

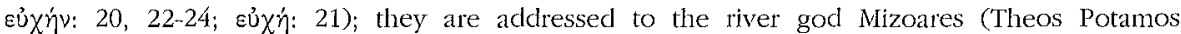
Mizoares: 20, 24; Potamos M(e)izoares: 21-22; Potamos Sozon Mizares: 23); one of them was made, again, by a group of friends (20). [AC]

81) B. IplikÇıŏlu - G. ÇLlgin - A.V. CFigin, "Termessos ve Egemenlik alani epigrafiktarihi coğrafi yüzey arasçtirmalari 1997", in $A S T$ 16.1, p. 381-385 [BE 2000, 618; SEG XLIX 1867-1871]: New texts from Termessos and its territory include an inscription which records the construction of a temple of Zeus Soter and the relocation of a cult statue ( $\Delta i \bar{\Sigma} \omega \tau \bar{j}$ er

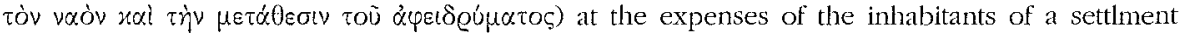

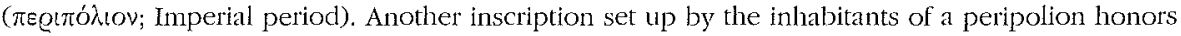
Trokondas, who had served as priest of the Megas Theos (Imperial period). [AC]

82) B. Ipl.ıkÇıĞlu - G. ÇELgin - A.V. ÇElgin, "Doğu ve kuzeydoğu Lykia-güneybati Pisidia epigrafik-tarihi cografi yüzey arastirmalari projesi 1999 çalismalari", in AST 18.1, p. 241-245 [BE 2002, 414]: Brief report on the discovery of four epitaphs from Lykia. The most interesting text is the long epitaph of Marcus Aurelus Torquatus, a former Lykiarches ( $\dot{\alpha} \pi \dot{o}$ Nuxiaex(ac), which is written on a heroon built by his father (Trebenna, 3rd cent. AD). [Torquatus gives instructions about the proper conduct of the funerary rites, which he introduces

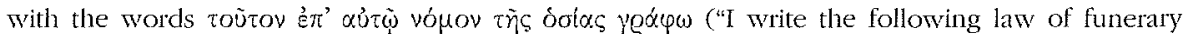
worship"); the word $\delta \sigma i \eta$ is used by IAMBurchos (Vita Pythag. 30, 184) to describe funerary rites. Torquatus' instructions begin with a funerary imprecation against those who would violate the grave: "no one should disturb (the buried persons), or dare bury anyone in addition to us or remove (the buried persons); and if some persons should wish or dare either to bury another person or to open the grave, let them be utterly destroyed together with their descendants ( $\dot{\xi} \xi \dot{\omega} \lambda \iota \varsigma$

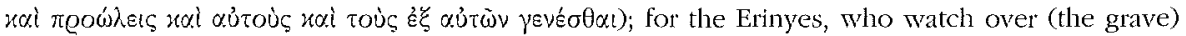

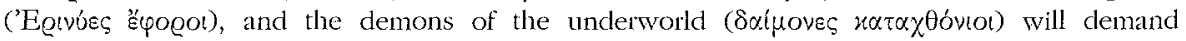

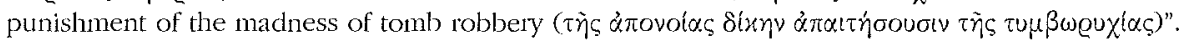


Then Torquatus demands his heirs to take care of the funerary worship as ordered by him: "And I

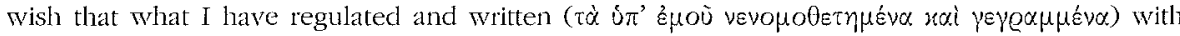

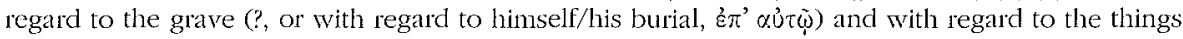

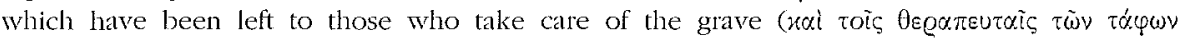

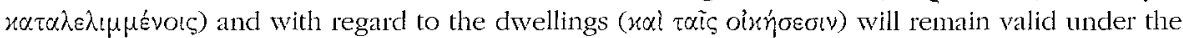
care of my future heirs; I wish and command that they (the heirs) do whatever I have determined

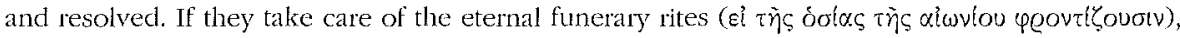

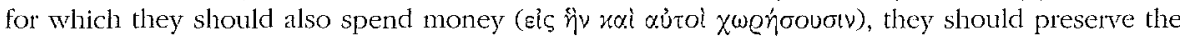
rites unmoved and unshaken. For if they do this, they will receive the fame of piety; if they do the opposite, they should justly be regarded as sacrilegious and tomb robbers"; for the expression

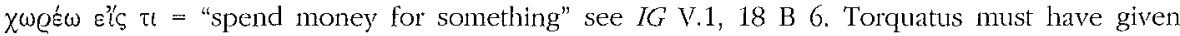
detailed instructions about the funerary rites in another document, probably in his testament]. Another epitaph was set up on the grave of a priestess of Theos Ouarathes (ị́eı. @eoì

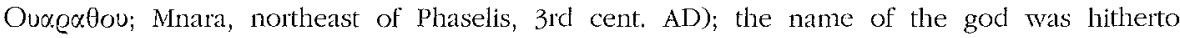
unattested (Luwian?) [but see infira $n^{\circ}$ 146]. Fines for any violation of the grave were payable to Zeus Solymeus [cf. epitaphs from Termessos: EBGR 1991, 40; 1992, 103; SEG XII 1268, 1270, $1278,1280-1282,1285-1286,1289,1300]$. [AC]

83) M.H. JAMESON, "A Hero Cult at Halieis", in Itbake, p. 197-202: Ed. pr. of two inscribed blocks found in a private house in Halieis (early 4th cent. BC). According to J.'s plausible reading, the inscriptions marked a place for the worship of the Dioskouroi: A: $F \alpha v \alpha(x o r v) \pi \alpha(\delta \circ v) \Delta$ ós, B:

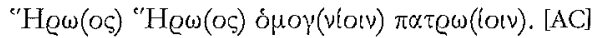

84) M. Johansson, "The Inscription from Troizen: A Decree of Themistocles?", ZPE 137 (2001), p. 69-92: A detailed study of the 'Themistokles' Decree' of Troizen and its numerous anachronisms leads to the conclusion that there is no evidence for the genuiness of the decree [similar conclusions are reached in two studies not used by $\mathrm{J}$.: A. Chaniotis, Historie und Historiker in den griechischen Inschriffen, Stuttgart, 1988, p. 259-272; J.K. DAvis, "Documents and "Documents" in Fourth Century Historiography, in P. CARLirr (ed.), Le Ni" siècle av. J.-C. Approches bistoriographiques, Paris, 1996, p. 29-39]. We single out the discussion of the gods mentioned in the decree; J. argues that the list of gods in lines 38-40 (Zeus Pankrates, Athena,

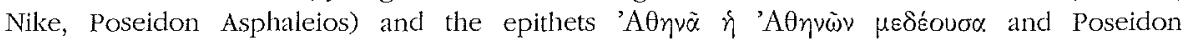
Asphaleios are incompatible both with a date of the decree in $480 \mathrm{BC}$ and with an Athenian

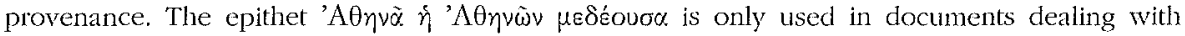
foreign affairs; there is no proven use of this epitheton in fifth-century Athens; although there are some fifth-century literary references to Zeus Pankrates, his state-cult is not attested; even more remarkable would be the separate mention of Athena and Nike in an Athenian decree of $480 \mathrm{BC}$; [in this context, J. does not take into consideration the discussion concerning the date of $1 G \mathrm{I}^{3} 35$ ]; Poseidon Asphaleios is well-known in the Peloponnese but absent in the Athenian epigraphic evidence. [IM]

85) S.I. Johnston, "Charming Children: The Use of the Child in Ancient Divination", Aretbusa 33 (2000), p. 97-117: The use of children in mediumistic divinatory practices is primarily known from magical papyri (e.g. PMG III 633-731; IV 850-929; V 1-53; VII 540-578; for a list of references see p. 101 note 9). The procedure can be reconstructed as follows: The practicioner selected a child, who met certain specifications. The child was then blindfolded and the magician called a god or spirit into him, using incantations and applying various materials. Removing the blindfold, the magician told the child to gaze at either a lamp's flame or at a bowl of specially prepared liquid. The god appeared in the liquid or flame and spoke to the child; in this respect, this form of divination differs from mediumism in which the god takes control of the medium and speaks through the medium. The child then gave the information to the practicioner (e.g. PMG VI 540-578). J. argues that the practitioners adapted forms of prophecy practiced in Delphi and Klaros and that two factors influenced the use of children: the reliability of children and the effort of itinerant magicians to substitute what they could not obtain (the media of the great oracles) with what was readily available (children). Gazing as a form of mediumistic prophecy could be practiced everywhere. [JM] 
86) C.P. Jonfs, "Imperial Letters at Ephesos", EA 33 (2001), p. 39-44 [BE 2002, 359]: J. republishes and discusses a dossier of three imperial letters concerning Ephesos (I.Ephesos 212). We present J.'s translations of the two letters that deal with religious matters. The first letter, sent by an anonymous emperor (Caracalla?), mentions suspension of taxes cluring the Artemisia: "Since it seems that the temple named after Artemis [--] of human [---], but [I have conceded?] the exemption from dues [---] of the iselastic Artemisia; [--- for I thought it fitting] for the most

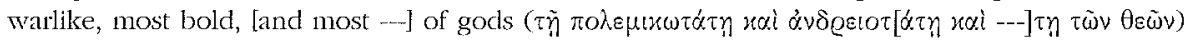

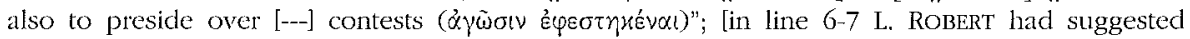

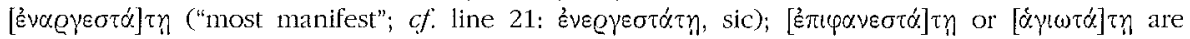
plausible alternatives (cf. supra $\mathrm{n}^{\circ}$ 53]. The third letter on the stone was sent by Caracalla to the provincial assembly of Asia and concerns the grant of a third neokoreia to Ephesos (c. 214-217 AD): "I approve for the decision whereby you [sided with] the most distinguished city of Ephesos, since [one should] attribute the [honor] with judgment. Therefore, since you (so) request and the leaders in Rome concur in approving (?), I have granted your request on behalf of the Ephesians, and I have [permitted] the city to be three times temple-warden. But in accordance with my modesty ( $\propto \alpha \tau \dot{\alpha} \tau \dot{\eta} v \dot{\varepsilon} \mu \eta \dot{v} \nu \alpha \hat{\delta} \hat{\omega})$ ), I transfer the neokorate named [after myself] to the most energetic

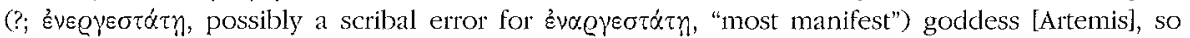

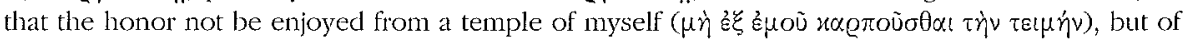

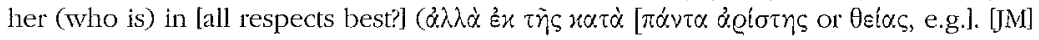

87) C.P. Jonfs, "A Statuette of Nemesis", EA 33 (2001), p. 45-47 [BE 2002, 353]: J. identifies a bronze statuette of a female figure with a measuring rod in her left hand (Charles Ede Ltd, General Catalogue 169, July 2000, $\mathrm{n}^{\circ} 11$; unknown provenance, Asia Minor?; 2nd/3rd cent.) as a statuette of Nemesis. According to a dedicatory inscription the statuette was given as a gift by Metrodoros to the "Lovers of arms" ( $\varphi$ i $\lambda$ ó $\lambda$ oı Nemesis presided over athletic competitions and gladiatorial shows. The statuette may have been carried in processions. An identification of the dedicant with a certain Metrodoros in Ephesos who is known to have dedicated cult statues ( $\alpha \gamma \alpha \dot{\alpha} \lambda \mu \alpha \tau \alpha$; I.Epbesos 1960), is not certain. The similarity of the statuette with the iconography of the Nemeseis of Smyrna makes a provenance from Smyrna also possible. [JM]

88) L. Jonnes, "An Inscription of a Homeric Cento", EA 33 (2001), p. 49-50 [BE 2002, 431; 2003, 627]: Ed. pr. of an inscription of unknown provenance in the Archaeological Museum of Kastamonou (Pontos) [4th cent. AD?]. The beginning of the text is missing; the rest consists of nine lines of a pastiche of phrases and lines from the Iliad and the Odyssey designed to produce

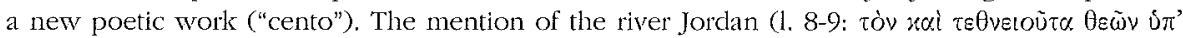

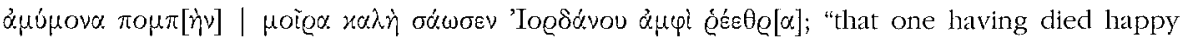
Fate saved through the illustrious protection of the gods by the waters of Jordan"; cf. Iliad 7, 135:

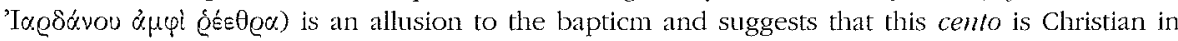
nature ( $c f$. St. UsHER, "Prolegomenon to the Homeric Centos", $A J P h$ 118 (1997), p. 305; id., Homerocenlones Eudociae Augustae, Stuttgart, 1999; Homeric centos in inscriptions: KAIBEL, EG $649,998-999,1009)$. The particular interest of this poem as a piece of evidence for the adaptation of pagan themes in early Christian literature lies in its reference to "the gods". [The consolatory nature of the poem suggests an epitaph, which can be dated to the 4th or 5 th cent. $\mathrm{AD}$ on the basis of the letter forms. For religious (pagan-Christian) ambiguities and pagan motifs in Christian inscriptions in this period see, e.g., EBGR 1998, 83 and 235; 1999, 175, and 258; 2000, 15, 128, and 193; see also infia $\mathrm{n}^{\circ}$ 122]. [AC]

89) D. Jordan, "Notes on Two Michigan Magical Papyri", ZPE 136 (2001), p. 183-193: J. presents revised texts of the magical papyri PMG LXXI (2nd/3rd cent.) and LXII 4-25 (3rd/4th cent.). The first text is a recipe for making an amulet; a probably inexperienced copist made a series of errors, the most interesting being the intrusion of the instruction "outside (write) the name of the great god in this phylactery"; the copist also included two versions of the formula for

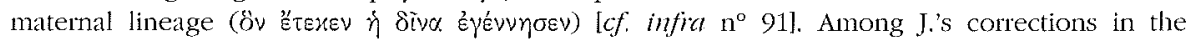

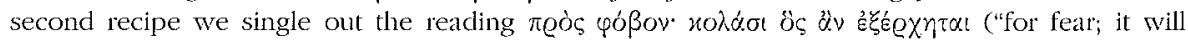

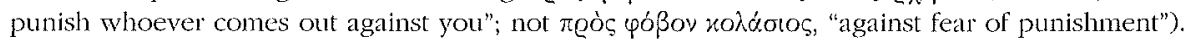




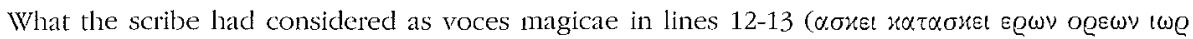

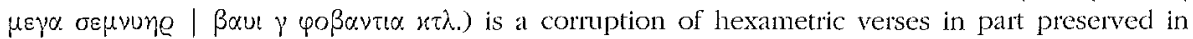

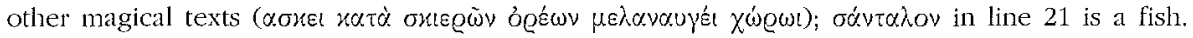
We present J.'s translations of the text: "(Spell of) Hekate Ereschigal against fear; it will punish whoever comes out (sc. against you). Say to him (or say the spell): 'I am Ereschigal, holding her thumbs, and not even one evil thing can happen to her'. And if he comes closer to you, say, grasping your right heel, 'I am Ereschigal, <grasping her right heel...> virgin, hound, snake, fillet, key, herald's wand; of Tartarouchos <bronze the sandal; of D[---]ros> gold the sandal', and you will get rid of him. 'Down from shadowy mountains in a region dark-gleaming (?), BAUI BAUI BAUI brightener, chaste ..., I have been initiated and into the chamber I descended' and the other (verses), 'I saw below ... virgin, hound' and all the remaining (verses)'. Say it at a triple crossroads and turn and flee, for she appears in these circumstances. Say: 'I (?) through the night (?) about whatever you want, and in sleep she will indicate it. And even if you are being led off to death, say these (verses) scattering sesame, and they (or she) will save you. 'PHORBA PHORBA BREIMO AZZIEBYA'. Taking bran from the first crushing and a sandalon-fish and the sharpest possible vinegar and steeping it, knead a cake and inscribe his name, and as if a secret say (i.e. whisper) Hekate's name over it distincly, and 'take this person's sleep away', and he will be sleepless and anxious." [JM]

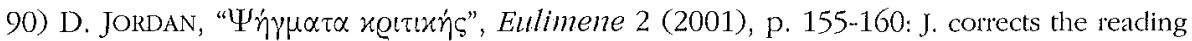
of the following magical texts: 1) In a defixio (AUDOLLENT, DT $41 \mathrm{~B}$, Imperial period) lines 1-2

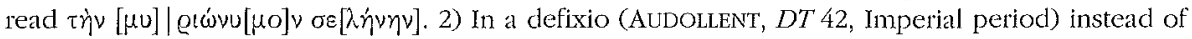

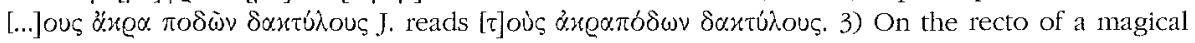

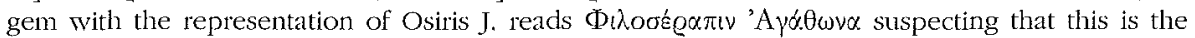
name of the owner of the ring. 4) On a phylactery (Rome, 4 th/5th cent. AD) J. reads $\Pi$ leò

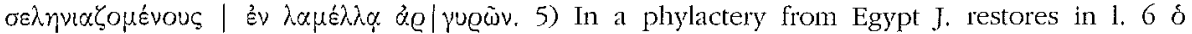

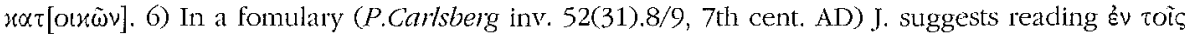

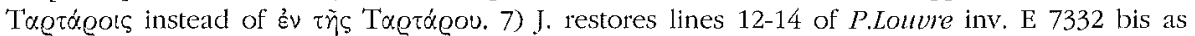

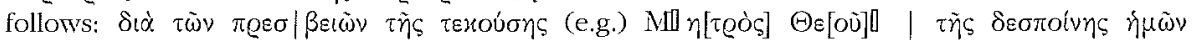
("through the intercessions of the birth giving Mother of God, our Lady"). [JM]

91) D. JoRDAN, "Intrusions into the Text of the Amulet P.Kellis G. I 87?", ZPE 137 (2001), p. 34: J. suspects that the word Sroxór $\tau$, written twice in the text of the amulet P.Kellis G. I 87 (4th cent. AD), is not part of the magical text (which should be read as $\sum \varepsilon \sigma \varepsilon \mu \varphi \theta \alpha$ ।

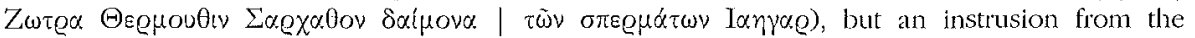
instructions given in the recipe from which the amulet was copied (i.e., "write SESEMPHTHA and below ZOTRA, etc."; cf. PMG II 163) [cf. supra $n^{\circ}$ 89]. [AC]

92) M. Kalava, "Livia and Nemesis", Arctos 34 (2000), p. 39-61: The temple of Nemesis in Rhamnous was rededicated to Livia $\left(\Theta \varepsilon \dot{\alpha} \Lambda \varepsilon \beta(\alpha)\right.$, probably in $\mathrm{AD} 45 / 46\left(I G \mathrm{II}^{2} 3242\right)$, a few years after Livia's official deification (17 January, 42). K. argues that the idea to honor Livia in this particular location and in association with the goddess of divine retribution came from Rome. As in the early 40 s there was a threat of war with the Parthians, the rededication of Nemesis' temple may have expressed the idea of vengeance on the Roman enemies. From the time of the Persian Wars Nemesis had become a symbol of vengeance of Persian hybris; since the wars against the Parthians were often assimilated with the wars against the Persians, the new interest in the cult of Nemesis may be related with the role of this goddess in imperial propaganda, as the avenger of Rome's enemies. The republication of an old hymn to Nemesis in Rhamnous (SEG XIX 222 and XXXVT 271) belongs to the same historical context. Since Augustus was regarded as guarantor of peace and was associated with Mars Ultor, it is understandable that his wife was compared to Nemesis. An association of Livia with Nemesis possible antedates her official deification and the rededication of the temple. $[\mathrm{AC}]$

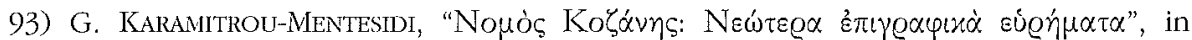
Synediro Epigrapbikes I, p. 49-78: Ed. pr, of 14 inscriptions found in various sites in the

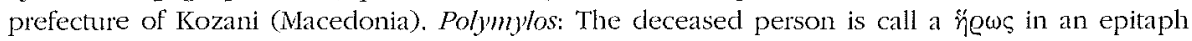


(3, 3rd/2nd cent.). Xerolimni: A stele was dedicated to Apollon [---]ios (9, 1st cent. BC/AD). Two other stelae, one of them probably representing Apollon with the kithara, bear fragmentary dedications to Apollon Mesioriskos (10-11, Imperial period). Several other dedications from Xerolimni (6: dedication to Apollon Nomios; 7: dedication to Apollon Mesioriskos; 8: dedication to Mezoriskos; 12: dedication to Apollon Mesioriskos and Artemis; 13: dedication to Apollon) have already been presented in $E B G R$ 1999, 133. [AC]

94) R.A. KeARsiey - T.V. Evans, Greeks and Romans in Imperial Asia Minor: Nixed Language Inscriptions and Linguistic Evidence for Cultural Interaction until the End of $A D I I I$, Bonn, 2001 (IGSK, 59): K.-E. present a corpus of the Greek-Latin bilingual inscriptions (including some texts in Greek, which use Latin terms) found in Mysia, Aiolis, Ionia, Karia, Lydia, Phrygia, Lesbos, Chios, Samos, Kos, and Rhodos. The corpus comprises epitaphs (1-110), honorary inscriptions (111-138) [but 136 is a dedication], dedications (139-146), and public donations (147). There are many bilingual dedications (cf. p. 153): to Artemis Ephesia/Diana Ephesia (157-161; I.Epbesos 29,509, 517, 857-858, early 2nd cent. AD), Iulia, Livia (identified with Aphrodite Geneteira) and Augustus (136; $I G$ XII 2, 537; Eresos), Iuno Atratinae/Tyche Atrateinas (142; H. MALAY, Researches in Lydia, Mysia and Aiolis, Vienna, 1999, n 67; Hyrkanis), Minervá Lindia/Athena Lindia (146; I.Lindos 323), Zeus Bennios (144; Appia, AD 79), Zeus Kersoullos (139; I.Hadrianoi 1; 1st cent. AD), and Zeus Megistos Soter (170; I.LaodL)*, AD 84/85; note that the Latin text only mentions Domitian). Other texts concern building works in the Artemision of Ephesos (148-150), the dedication of a public buildings and statues to Artemis Ephesia (155; I.Ephesos 3003), the restoration of the sacred road from Miletos to Didyma (162; I.Didyma 56), the dedication of a temple and halls in Blaundos (168; IGR IV 719+1700), and the rebuilding of a temple of Dionysos, which had been destroyed by an earthquake, in Samos (171; SEG XXXV 949, $\mathrm{AD}$ 47/48) [now in $I G$ XII 6.2, 483]. A confession inscription in Greek uses the term pekoulion $/$

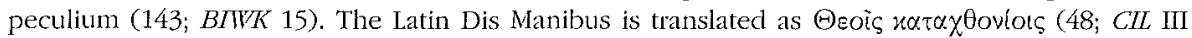

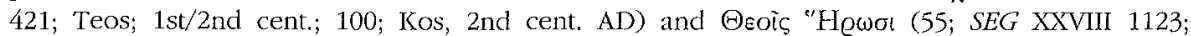
Eumeneia, 1st cent. AD). For some influence on the words which designated parts of funerary

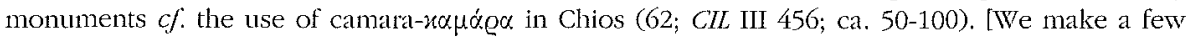
observations. In an epitaph from Didyma (11; I.Didyma 525; 1st cent. BC/AD) the deceased person is called a beros only in the Greek version. In an epitaph from Ephesos (24; I.Ephesos 4123 ; ca. 50 AD) the Latin epitaph is followed by the Greek text of a funerary foundation. Among the interesting texts we mention the funerary epigram for Marcellinus, who seems to have commited suicide or have died of sorrow (75; I.Ephesos 2103; "others with wreaths, libations, and tears and songs honour your tomb, Marcellinus; instead of libations your father poured out his own life, wishing to have a common name and death"); this text is now included in MERKELBACH - STAUBER, Steinepigramme I 03/02/65. One notices a different mood in the two epigrams (Latin and Greek) for Iope (85; Teos, 2nd cent. AD; Steinepigramme I 03/06/04); the Latin epigram has no words of consolation, while the Greek epigram tries to give comfort to Iope's mother: "place this in your heart as comfort for your grief over me, that even the children of the blessed ones went below". A similar difference may be seen in another epitaph for a child, probably written by the Roman teacher who was buried in the same grave $(91 ; T A M$ V 2, 1119; Thyateira, 2 nd cent. $\mathrm{AD})$. The epigram exploits the common theme of the dwelling of the dead among the Blessed ones, however, not as consolation - as in most epitaphs -, but as scorning of the parents: "the laws of nature and the arrangement of the fates prevail over useless vows, laments and the spirits of the divine ones. You have scomed your father and mother, O most wretched son, since you dwell in the Elysian fields and the meadows of the blessed ones"]. [ACl

95) M.F. KiLmer - R. Develin, "Sophilos' Vase Inscriptions and Cultural Literacy in Archaic Athens", Phoenix 55 (2001), p. 9-43: A detailed study of the inscriptions on the vases painted by Sophilos (Athens, c. 590-570 BC) suggests that this painter had a very good knowledge of mythology - also of different literary versions of myths - and that he possibly also introduced his own variations of familiar stories. K.-D. suggests that the name Nuod on a fragment of the so-called 'Wedding Dinos' of Sophilos ( $\mathrm{f}$ : $\mathrm{i}$ ) in the National Museum of Athens designates the Nymphs of Mount Nyssa (Nyssai), known to have been the nurses of Dionysos, and reject the assumption of a scribal error for $<\mathrm{M}>$ vou (the Muses). [JM] 
96) D. KnofPfler, "Oropodoros: Anthroponomy, Geography, History", in Greek

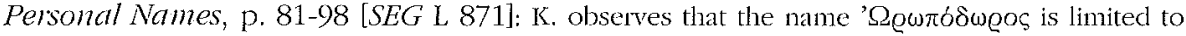
only two cities: Oropos (two instances) and Eretria. In composite names consisting of a proper name and - $\delta$ woos the first component is the name of a god, a divine epiklesis, the name of a hero (never a city founder), and a toponym (mountain or river). In the case of Oropodoros the first component is the name of a hero associated with a homonymous river (Oropos = Asopos); [for names deriving from river-gods see infia $\mathrm{n}^{\circ} 138$; for doubts on K.'s assumption the Oropos is the Eretrian clialect form of Asopos see L. DuBOrs, BE 2001, 140]. [AC]

97) D. KNOEPFler, "Loi d'Érétrie contre la tyrannie et l'oligarchie", BCH 125 (2001), p. 195-238: Ed. pr. of a new fragment of the Eretrian law against tyranny (cf. $l G$ XII 9, 190, 4th cent. BC). Whoever killed a person who attempted to overthrow the democratic constitution

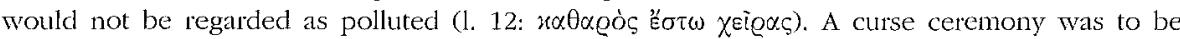
performed by the pricsts and the priestesses on the occasion of the Dionysia and the Artemisa

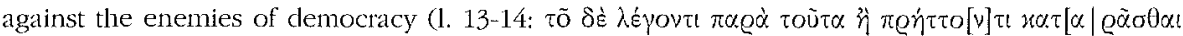

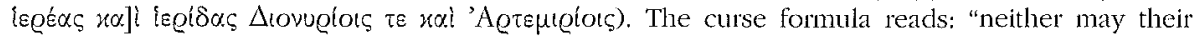
wifes give birth to children from them according to nature nor their livestock, and their land may not be fertile; and should they have offspring, may their children not be legitimate, but all perish,

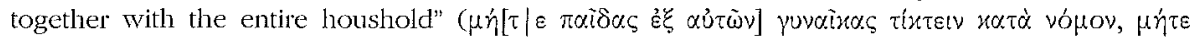

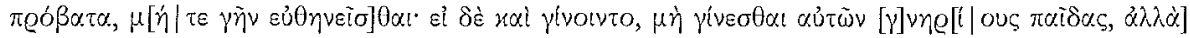

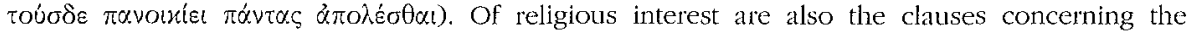
dedication to Artemis Amarynthia of one tenth of the property of anyone who attempts to

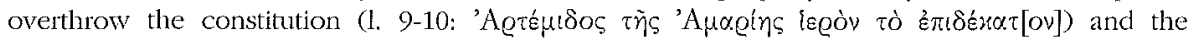
prohibition against his burial in Eretrian territory (1.10). [AC]

98) D. KNofPrler, Décrets érétriens de proxénie et de citoyenneté, Lausanne, 2001 (Eretria, XI) [BE 2002, 335]: K. presents the ed. pr. of 19 proxeny and citizenship decrees of Eretria and studies in detail another 31 previously edited decrees (5th-2nd cent.). Many of the new texts mention the sanctuary of Apollon Daphnephoros as the place where the inscriptions were to be set up (4, 8, 10, 12-13, 14?, and 15). In IG XII 9, $228 \mathrm{~K}$. suggests restoring in 1. 7: ['̉

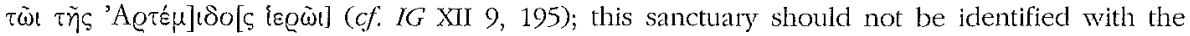
famous sanctuary of Artemis Amarynthia, but should be located in the city of Eretria, near the Daphnephorion (p. 138-141; cf. p. 166). [AC]

99) Ch. КоккाNI , Die Opramoas-Inschrift von Rbodiapolis. Euergetismus und soziale Elite in Lykien, Bonn, 2000 [SEG L 1355]: K. presents an improved edition of the dossier of documents from Rhodiapolis concerning the local benefactor Opramoas (2nd cent. AD). In this context she discusses the office of the high priest of the emperor cult in Lykia (p. 196-215). [AC]

100) E. Kosmetatou, "The Delian Hieropoioi of 171 B.C.", Epigrapbica 63 (2001), p. 256-258: On the basis of squeezes K. discusses the identity of the hieropoioi of the year 171 $\mathrm{BC}$; the colleague of Alexikos as hieropoios was not Epitrophon (written by mistake in $I G$ XI 2 , 133 1. 67), but Her[---] (SEG XXXV 882). [AC]

101) P. KovÁcs, Corpus Inscriptionum Graecarum Pannonicarum. Editio maior; Debrecen, 2001: K. presents an improved and enlarged edition of the corpus of Greek inscriptions found in Pannonia. No nerv texts. Dedications: to Asklepios (88, Aquincum, by a doctor),

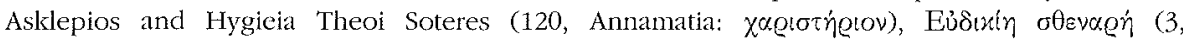

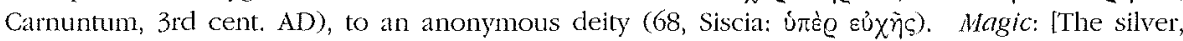
gold, and bronze objects which K. regards as curse tablets (12-16: Carnuntum, 3rd cent. AD; 125: Cibalae; 152: unknown provenance) are in fact phylacteriesl. A silver phylactery for the healing of headache contains a historiola referring to Artemis Ephesia and Antaura (12, Carnuntum, 3rd cent. AD); three other silver phylacteries (13-16) contain magic names, words, and charakteres (13: $\left.\sum \alpha \beta \alpha \dot{\omega} \theta\right) ; 15$ : the palindromic $\left.\alpha \beta \lambda \alpha \tau \alpha v \alpha \beta \lambda \alpha\right)$; a gold phylactery mentions $A \beta \rho \alpha \sigma \alpha \zeta$ (143, unknown provenance). A Greek-Latin bilingual curse tablet against Eudemos is designated as the "seal of

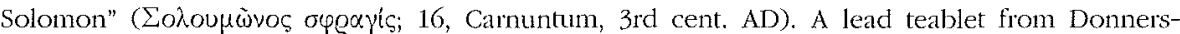
kirchen $(48,3$ rd cent. AD) seems to be a curse tablet. Another curse tablet from Siscia contains 
names and charakteres (69). For the curse tablet from Savaria (50, 3rd cent. AD) see EBGR 1990, 102. The corpus includes many magical gems (Camuntum: 42-47; Veszprémvarsány-Lázi: 53; Siscia: 71; Brigetio: 79, 81-82; Pusztaszabolcs: 106; Székesfehérvár: 108; Intercisa: 118; tunknown provenance: 146-148, 161), some of them showing Abrasax (42: I $\alpha \omega ; 43$ and 161: I $\alpha \omega$, A $\beta$ e $\alpha \sigma \alpha$; 53: $\alpha \beta \lambda \alpha \theta \alpha \nu \alpha \beta \lambda \alpha ; A \beta \varrho \alpha \sigma \alpha \xi, \Sigma \varepsilon \mu \varepsilon \sigma \lambda \alpha \mu, \Delta \alpha \mu \nu \alpha \mu \varepsilon v \varepsilon 0 ; 71:$ I $\alpha \omega ; 146: A \beta \varrho \alpha \sigma \alpha \xi, \sum \varepsilon \mu \varepsilon \sigma \varepsilon l \lambda \alpha \psi \mid$

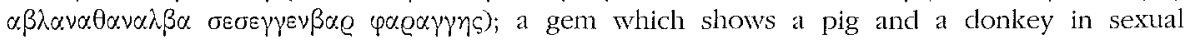
intercourse (obverse) is inscribed with a sequence of vowels (79, Brigetio, 3rd cent. AD), Varia:

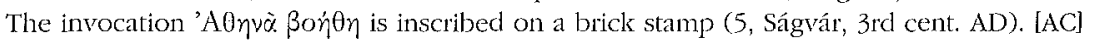

102) J.H. Kroll, "The Greek Inscriptions of the Sardis Synagogue", HThR 94 (2001), p. 5-55 [BE 2002, 614]: K. presents a coprus of 79 inscriptions in Greek from the Jewish Synagogue at Sardis, which is one of the most important dossiers of texts for the Jewish communities in Asia Minor in late Antiquity, together with the texts from Aphrodisias fon the dating of the latter texts to the same period (4th-6th cent.) see now A. CILANotis, "The Jews of Aphrodisias: New Evidence and Old Problems", SCI 21 (2002), p. 209-242]. The inscriptions belong to the 4 th-6th century phase of the Synagogue, the only sure exception being the mosaic donor inscription found in the Main Hall and dating to $270 \mathrm{AD}$ (3). Most of the texts are donor inscriptions often with a statement that the donation was made in fulfilment of a pledge or vow $(1,5,9-10,18-20,22,25-26,29-34,36-37,43,46-48,50-51,54,57,59,61-62,66-68,72,78)$. Six of the donors are identified as theosebeis $(8,9,22,57,59,66)$. The donor Samoe (4), who was

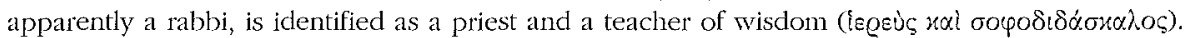

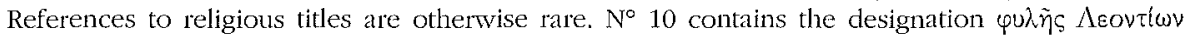
which K. unterstands as a Hellenistic adaptation for the Tribe of Judah, described in Gen. 49, 9 as a lion. According to $K$. the donor in $n^{\circ} 10$ refers explicitly to his membership in the Tribe of Judah in order to distinguish himself from the two theosebeis (8-9) who donated the adjacent mosaics along the west corridor of the forecourt. The word vouopuk $\alpha$ nov in $n^{\circ} 63$ refers to the

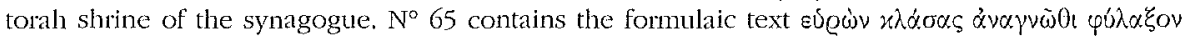
("having found, having broken open, read, observe") referring to the reading and observation of the Law. [JM]

103) I.V. KsEnOfONTOVA, "Panathenaean Amphoras from the State Museum of Orient", IDI 235.4 (2000), p. 181-185 [in Russian; English summary]: Ed. pr. of two Panathenaic amphoras from Ulyab-Borrow (Adygea, c. $440-400 \mathrm{BC}$ ). Both of them bear the standard inscrip-

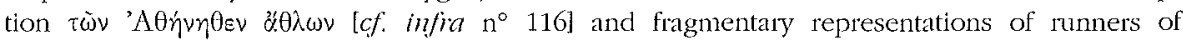
dolichos, and a judge and two athletes respectively. [AC]

104) J. Kubínska, "Tiberius Claudius Lycus de Thessalonique et son thiase", ZPE 137 (2001), p. 153-160: K. discusses a group of texts in Thessalonike which concern the councillor Ti. Claudius Lykos. Lykos, possibly inspired by the funerary monuments of Asia Minor, made a funerary foundation consisting of a heroon, a garden, and a cultivated estate (IG X 2.1, 608); the

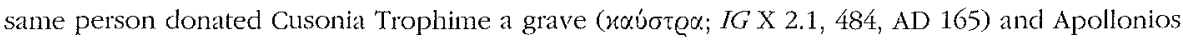

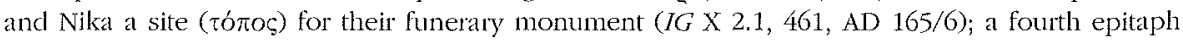
refers to the butial of a woman in a $\pi \alpha \tau \varrho x \partial \nu$ Q $\alpha y=i o v$ of Lykos (IG X 2.1, 609, after AD 212). Lykos is also known from a list of members of a Dionysiac association found in the Serapeion (IG $X 2.1,244$ ). This association may be identified with a Dionysiac association dedicated to the cult of Zeus Dionysos Gongylos, known from an earlier inscription which was also found in the Serapeion $(I G \times 2.1,259,1$ st cent $A D)$; both texts mention a sacred official called $\beta \eta \sigma u \varrho \tau \eta$ s. The earlier text concerns a dedication of vineyards to the god for the celebration of rituals (orgia) and banquets; [K. points out that $I G \times 2.1,259$ mentions two priests, in lines 21 and 32-33, whereas there is no priest in $I G \times 2.1,244$ - probably because his name was written in the lost part of the stele; it should be noted, however, that the second priest in $I G \times 2.1,259$ is not the priest of the Dionysiac association, but the priest of the Sarapeion who allowed the erection of the stele in his

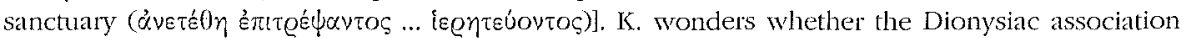
occasionally held meetings in the Serapeion. A third inscription (IG X 2.1, 60, AD 155/6) seems to concern the same association, since Furius Preimigas appears as archineokoros in this text and in IG $\mathrm{X} 2.1,244 . \mathrm{K}$. mentions the many unanswered questions with regard to the activities of Lykos, 
being inclined to believe that the Dionysiac association changed its chatacter in the course of time and had become "un sorte de club politique où le culte de Zeus Dionysos Gongylos était seulement un élément formel". [The texts themselves do not provide any information that could support this assumption]. [AC]

105) A. KajTAR, "Die Kontakte zwischen Ägypten und dem Horn von Afrika im 2. Jh. v.Chr. Eine unveröffentlichte Inschrift im Nationalmuseum Warschau", JfurP 29 (1999), 51-66, [BE 2000, 713]: Ed. pr. of a dedication made to Zeus Soter Sarapis, Isis Megale Meter Theon, Harpokrates, Pan Euhodos, Kronos, Dionysos, the Dioskouroi, and Herakles Kallinikos on behalf of Ptolemy VIII, Kleopatra II and Kleopatra III (Koptos?, 133 BC). The deities combine three qualities: protectors of the kingdom (Zeus Soter, Isis, Harpokrates, Dionysos), protectors of travellers (Zeus Soter Sarapis, Pan Euhodos-Min, the Dioskouroi, Kronos-Geb, Herakles Kallinikos-Chons), and local gods of Koptos (Min, Geb, Chons). If Zeus is identified with Sarapis - and the two names should not be separated with a comma -, this is the earliest epigraphic attestation of the identification of the two gods. The dedicants were two officers who had returned from the dangerous mission of bringing presents from the Aromatophoros (Horn of Africa, Bab el-Mandeb; for a similar mission cf. A. BERnand, Pan du désert, Leiden, 1987, $\mathrm{n}^{\circ}$ 86). [AC]

106) A. KAJTAR, "A Metric Epitaph from Galilee Commemorating one Phoibadios", JIurP 30 (2000), p. 53-55 [SEG L 1465]: L. republishes a metrical epitaph from Belvoire (between Skythopolis and Tiberias, 2nd cent. $\mathrm{AD}$ ), improving the reading of the last verse: $\sigma \omega \mu \alpha$. Фot $\beta \alpha \delta l_{0}$

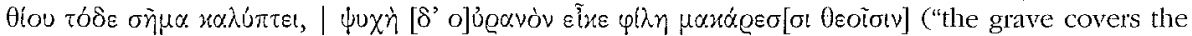
body of the godly Phoibadios; his soul, dear to the blessed gods, has gone to heaven", [now included in MERKELBACH - STAUBER, Steinepigramme III 21/21/05; for similar ideas see EBGR 2000, 31]. [AC]

107) E, LANZillotTa, "Il culto del Demo in Atene", in Miscellanea Gasperini I, p. 495-

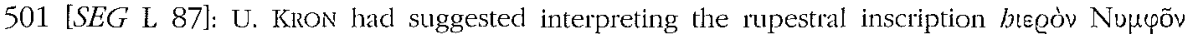

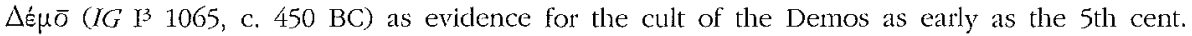
According to L. the word $\Delta \varepsilon \dot{e} \bar{o}$ refers to the Nymphs ("sanctuary of the Nymphs of the Demos" or rather "of the deme"). [P. GAUTHIER, $B E$ 2001, 149, more plausibly suggests translating "sanctuaire des Nymphes; (il est) public"; cf. R. PARKER, Atbenian Religion: A History, Oxford, 1996, p. 233. $G$. also observes that there is no evidence for the cult of the Demos until the late $3 r d$ cent. $B C]$. [AC]

108) L.R, LiDonnici, "Single-Stemmed Wormwood, Pinecones and Myrh: Expense and Avalibility of Recipe Ingredients in the Greek Magical Papyri", Kennos 14 (2001), p. 61 91: L. places some of the ingredients of magical recipes (frankincense, pinecones, wormwood, and myrth) in the context of the economy of the Roman Empire, demonstrating the availibility, but also the high prices, of these substances. This suggests an urban setting for the practitioners who used the recipes of the magical papyri, especially for divinatory purposes. On the other hand, spells for health, healing, good business and aversion of anger tend to be less expensive and simple. The diversity of ingredients and the co-existence of sophisticated and simple material in the magical formularies may reflect the diversity of their sources and the diversity of the social contexts of magic. [JM]

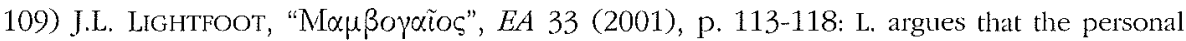
name Mapßoyaios was created in Roman Syria by the devotees of the goddess of

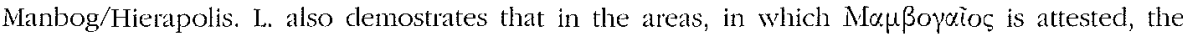
Syrian goddess had a special popularity. The coincidence of the distribution of the name and the appeal of the cult is well illustrated by the presence of Kommagenians among the bearers of this name. [JM]

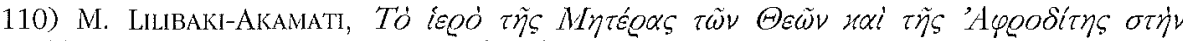
$\Pi \varepsilon \dot{\lambda} \lambda \alpha$, Thessalonike, 2000 [SEG L 609-611 bis]: L.-A. publishes the results of the excavation of the sanctuary of the Mother of Gods in Pella and its finds and discusses the cult of Meter 
Theon and Aphrodite (p. 205-219). The sanctuary was built in the late 4 th cent. BC, enlarged in the late $3 \mathrm{rd}$ /early 2 nd cent., and destroyed in the early 1 st cent. BC. L.-A. presents the ed. pr. of three Hellenistic dedications addressed to Aphrodite (p. $188 \mathrm{n}^{\text {"n }}$ 597-598, Hellenistic period), Meter Theon (192 $\mathrm{n}^{\circ}$ 619), and Meter Theon Epekoos (p. 215f.). A third text, written on an altar, reads Aiólov | Texin (p. 192-193 $n^{\circ}$ 620). [L.-A. interprets it as the personal name Aiolos, but in a forthcoming article in Eulimene 4, P. CHRYsostomou observes that this is an altar of Aiolos]. [AC]

111) M. LIVAdioti - G. Rocco, "Il santuario di Asklepios, Hygeia e Homonoia nel demo di Isthmos a COO", in J.-Y. MARC (ed.), Constructions publiques et programmes édilitaires en Gièce entre le It sièvle av.J.-C. et le I" siècle ap.J.-C., Paris, 2001 (BCH Suppl., 39), p. 371-384: After a summary of the excavations conducted from 1912 onwards in a sanctuary consisting of two temples and a theater in the ancient demos of Isthmos (modern Kephalos in KOS), L.-R. conclude on the basis of the epigraphic finds that this sanctuary was dedicated to Asklepios, Hygieia, and Homonoia. The cult of this triad is also attested in a sacrificial calendar ( $P H 401=L S C G 169 \mathrm{~A}$ ); one of the two temples was dedicated to Asklepios and Hygeia, the other to Homonoia. The preoccupation with the cult of Concord (cf. $P H$ 61; Tiical 137b) may be related to conflicts between Koans and Kalymnians. The foundation of the sanctuary may be placed in the aftermath of the Cretan War (late 3rd cent. BC). [AC]

112) C. LÖHR, Griechische Familienueihungen. Untersuchungen einer Repräsentationsform von ihren Anfängen bis zum Ende des 4. Jhs. v. Chr., Rahden, 2000 [SEG L 1712]: L. presents a systematic study of dedications made by or on behalf of family members in the Archaic and Classical periods. The catalogue (p. 8-152) contains 148 inscribed dedications (n ${ }^{\text {'m }} 1$ $19,21-35,37-42,45-48,50-52$, 54-56, 59-61, 63-68, 70-72, 75-78, 80-84, 86-90, 92-99, 101-135, 139, $141,143-161,164-166,168-171$, and 175). The texts are republished with German translation and comments on the chronology, the form of the dedication, and its historical context. In the systematic part of the book ( $\mathrm{p}, 153-226$ ) L. focuses on the family relations of the dedicants, the iconography, and the background of the dedications (dedications made on behalf of relatives, thanks-giving dedications after healing or rescue from danger), and on dedications made by many related persons. His main conclusion is that in the 6 th and 5 th cent. $\mathrm{BC}$ family dedications concerned a very close circle of family members (often father and son), whereas from the 4 th cent. $\mathrm{BC}$ onwards dedications that cover two or thee generations became more common. [AC]

113) A. Lukaszfwicz, "La stèle de Patoubasthis et les vaches sacrées à Edfou", IJurP 29 (1999), p. 75-78 [BE 2000, 720; SEG XLIX 2116]: In a dedication at Edfou (SB 7694; Edfou,

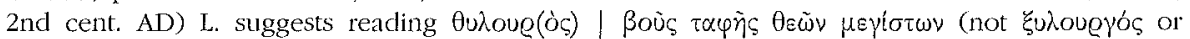
Outovexous). According to this reading the dedicant was "porter of the graves of the cows of the Greatest Gods" [cf. the remarks of J. BINGEN, BE 2000, 720]. [AC]

114) W. Luppe - R. Scholz, "Ein Leipziger Mythologie-Papyrus", AfP 47 (2001), p. 4-18: Ed. pr. of fragments of a papyrus (unknown provenance, 2 nd cent. AD) which contained the work of an anonymous mythographer. The text treats in prosa the legends of Perseus (the death of Akrisios, the foundation of Mykenai), Bellerephontes (the accidental killing of a citizen, his exile to Proitos, his journey to Lykia), Hyrieus - Poseidon's son - and the sons of Hyrieus. The text provides hitherto unknown information conceming Klonie, the mother of Krinakos, Echion, the son of Hyrieus, Euboe, Hyrieus' wife or lover, the colonisation of Achaia by Krinakos and Echion, and the origin of the Abantes. [For an addition see W. Luppe, "Nachtrag zum Leipziger Mythologie-Papyrus", ZPE 137 (2001), p. 24]. [AC]

115) E. Lupu, "The Sacred Law from the Cave of Pan at Marathon", ZPE 137 (2001), p. 119-124 [BE 2002, 183]: L. republishes a stele dedicated by three ephebes and their fellow ephebes to Pan and the Nymphs in the cave of Pan at Marathon (SEG XXXVI 267, 61/60 BC). The last lines are a sacred law which regulates entrance to the cult cave by listing items that were not allowed inside: "The god forbids one to cary in either colored garments ( $\chi \varrho \omega \mu \alpha$ tivov) or dyed garments ( $\beta \alpha \pi \tau o ́ v)$ or [--]". This regulation cannot have been formulated by the ephebes themselves, who probably quote an already existing sacred law, allegedly originating from the god. $\mathrm{L}$.

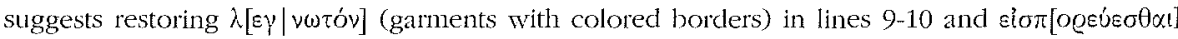


in line 10. The law seems to have allowed only persons with white clothes to enter the sacred cave (cf. LSAM 14 and 35; LSCG 65 lines 15-16; LSCG Suppl. 91). L. comments on analogous regulations and on the joint cult of Pan and the Nymphs. [The Athenian ephebes are known to have worn a particular ephebic garment, the black chlamys; see Chr. PÉLÉrIDIs, Histoire de l'épbébie attique des origines à 31 avant Jésus-Cbrist, paris, 1962, p. 15-16; this possibly explains why ephebes set up this inscription, warning their fellow ephebes who patrolled the territory not to enter the cave with their ephebic cloak. For dedications of ephebes in sacred caves, $c f$. the dedications in the Korykean Cave on Parnassos (L. RoBERT, Éludes anatoliennes, Paris, 1937, 108f; cf. SEG XXXII 626)]. [AC]

116) J.-J. MAFFre, "Céramique attique récemment découverte à Apollonia de Cyrénaïque", CRAI (2001), p. 1065-1079: M. reports the discovery of three Panathenaic amphoras in the cemetery of Apollonia in Kyrenaika. One of them is very fragmentary (c. 370-365); the other

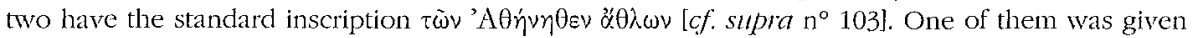
to a winner in cliaulos (c. 370-365), the second in an unknown discipline (344/3 BC). [JM]

117) I.A. Makarov, "On the Interpretation of a New Chersonesian Document", VDI 230.1 (2000), p. 112-118 [in Russian; English summary]: M. interprets a very fragmentary text from Chersonesos in Tauris (2nd cent. BC) which mentions Hermes [EBGR 1997, 352] as a decree or a lex sacra concerning the institution of ephebeia and establishing athletic competitions

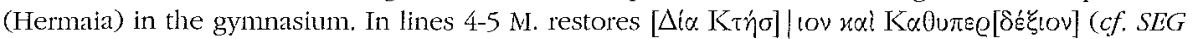
XV 427); a cult of Zeus Kathyperdexios was hitherto unattested in Chersonesos. The reorganisation of the ephebic institutions may be connected with the Scythian attacks in the late 2nd cent. BC. [AC]

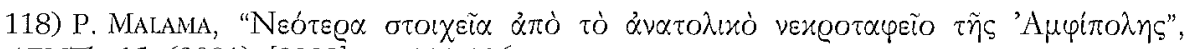
AEMTh 15 (2001) [2003], p. 111-126: Ed. pr. of a new gold Orphic lamella found in a

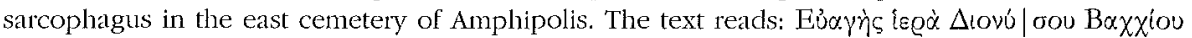

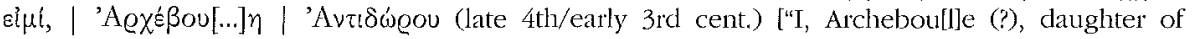
Antidoros, bright and sacred, belong to Dionysos Bakchios"; the text belongs to the group of Orphic texts, in which the deceased person reveals his/her identity as an initiate (cf. $E B G R$ 1998, 89)]. [AC]

119) P. MCKECHNIE, "Flavia Sophe in Context", ZPE 135 (2001), p. 117-124: The funerary epigram of Flavia Sophe (Rome; CIG 9595a), set up by her husband (in continent marriage), is an important piece of evidence for the Valentinian sect (cf. A. MCGuIRE, "Women, Gender and Gnosis in Gnostic Texts and Traditions", in R.S. KRAEMER - M.R. D'ANGELO (eds.), Women and Cbristian Origins, New York / Oxford, 1999, p. 257-299). The gravestone bears an epitaph on the front (A) and a second epigram, possibly of slightly later date, on the back (B). M. presents a new

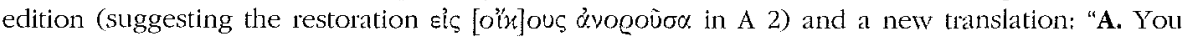
whose desire was for the light of the Father ( through the baths of Christ with imperishable holy perfume, you hastened to gaze on the divine

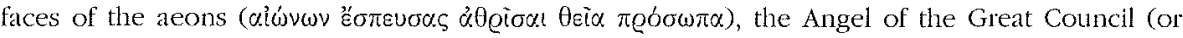
Councel, $\beta$ ou $\lambda \dot{\eta}$ ), the true Son, when you went to the Bridal Chamber and rose [incorruptible] ([á $\varphi \theta \alpha \varrho \tau 0] \varsigma$ ) to the Father's [housel -- B. This woman did not have a common end of her life when she died. She died, and she lives, and she sees in reality the light imperishable. She lives to

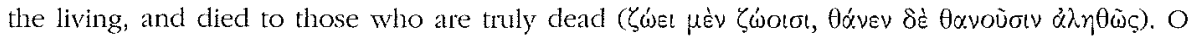
earth, why to you marvel at the nature of the deceased (véxuos yévoৎ)? Are you frightened?" [in

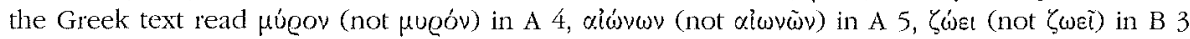

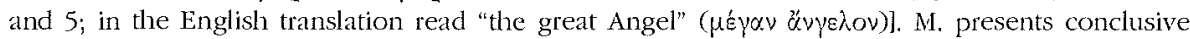
evidence for a date in the 4 th cent. $\mathrm{AD}$ (not in the $2 \mathrm{nd} / 3 \mathrm{rd}$ cent.) and discusses the ritual of the 'Bridal Chamber' in the Valentinian sect (cf. CIL VI 37231 and L. MORETT, "Iscrizioni greche inedite di Roma", Bulletini Comunale 75 [1953-55], p. 83-86, 4th cent. AD). [With respect to the content of the second epigram parallels are to be found in pagan epigrams which claim that the deceased had not really died; e.g. Steinepigramme I 02/09/06, 02/09/12. A more close, contemporary parallel, may be seen in the grave epigram for Claudia from Aphrodisias (Ch. RoueCHÉ, 
Aphrodisias in Lale Anliquity, London, 1989, $\mathrm{n}^{\circ}$ 153; MERKrLbaCH - STAURER, ibid. I 02/09/28,

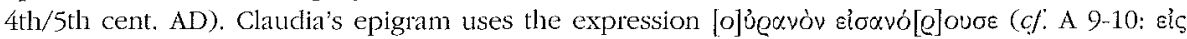

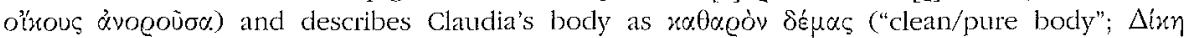

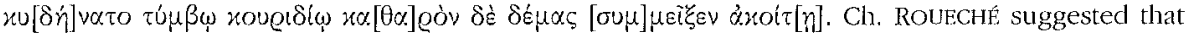
Claudia had died before marriage and that the tomb was her husband ("Justice has honoured you with the tomb of the dead, and has wedded your pure body (with it as a) lawful husband"); the correct sense is given by R. MERKFLLBACH and J. STAUBER (although their translation ommits

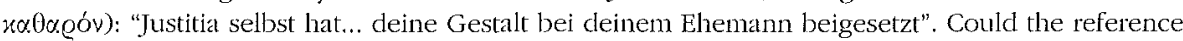
to a pure body of a married woman be an allusion to continent marriage?]. [AC]

120) R. Merkelbach - J. STAuber, Steinepigramme aus dem griechischen Osten. Band 2: Die Nordküste Kleinasiens (Mammarameer und Pontos), Leipzig, 2001: The great value of the corpus of Greek epigrams from the Greek East (critical edition, translation, brief commentary) has been underlined in Kemos 14 (2001), p. 319-320. The second volume covers Mysia, Bithynia, Paphlagonia, and Pontos; newr texts are marked with an asterisk.

Rituals: The composer of a fragmentary epigram asserts that he worships an anonymous god

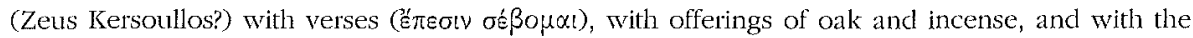

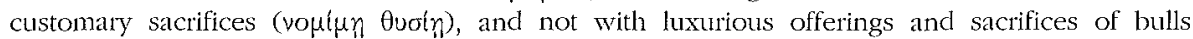
(08/08/03, Hadrianoi, 2nd/3rd cent.). Several epigrams highlight the ritual activities of the deceased persons: the epigram for the prytanis Theodotos commemorates the pleasure he had in

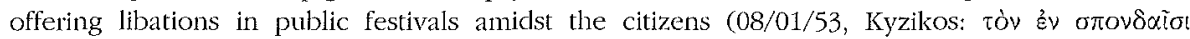
$\left.\gamma \varepsilon \gamma \alpha \theta \delta \dot{\tau} \alpha \pi \circ \nu \lambda \dot{0} \mu \varepsilon \tau^{\prime} \dot{\alpha} \sigma \tau \hat{\omega} \nu\right)$; a mystes of Dionysos is praised for his service during the festival of

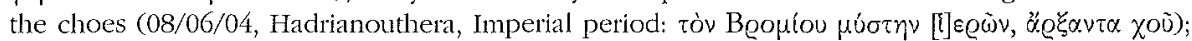
the epitaph for a priest of Zeus refers to the fact that he offered libations with his own hands

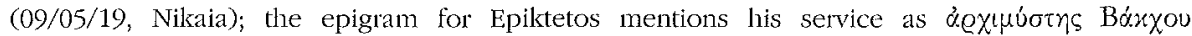
Meyód $\lambda$ ou (09/05/86, Nikaia); Meniketes, a mystes of Isis, refers to the construction of a bed for

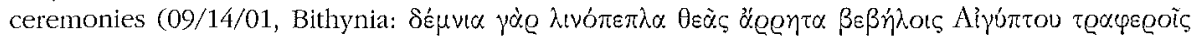
$\delta \dot{\omega} \mu \alpha \sigma \nu \dot{\alpha} \varrho \mu \sigma \sigma \alpha \mu \alpha v)$; the epitaph for the mystes Aimilianos describes his participation in the

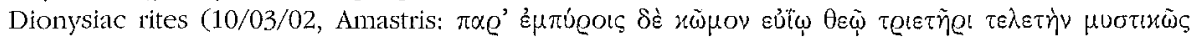

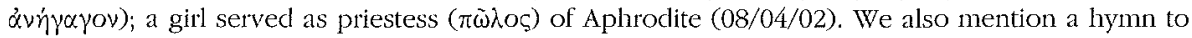
Anubis (09/01/02, Kios, 1st cent. BC/AD).

Dedications: to Apollon (09/06/02-03), Apollon Soter (09/04/01), Asklepios and the Nymphs

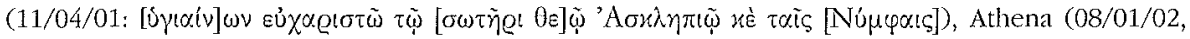

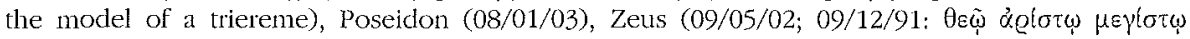

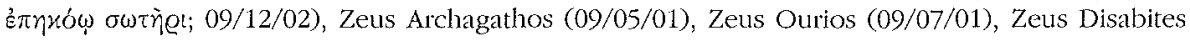
Alexikakos (11/11/01), Sarapis and Isis (08/01/40, the statue of a young warrior who fell in war). The reason for the dedication is sometimes stated: an oracle (08/08/02), a dream (09/05/01: $x \alpha \tau \dot{\alpha}$.

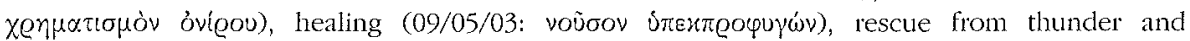

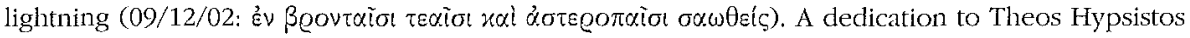
in Amastris defines the qualities of the god (10/03/01) [see $E B G R 2000,127)$.

Divination and oracles: An oracle of Zeus Ammon in Siwa concerns Kyzikos (08/01/01, Kyzikos, c. AD 130), a very fragmentary oracle of Apollon Klarios concerns Nikomedeia (09/06/01). Gauros, who "received the trustworthy words of the prophets", was either the scribe of an oracular sanctuary or a recipient of an oracle; he probably composed a literary work about the victory of Octavian (08/08/01, Hadrianoi). An oracle of Apollon Klarios contains a lex sacra concerning a procession of women (for Artemis or Demeter); they should attend the procession

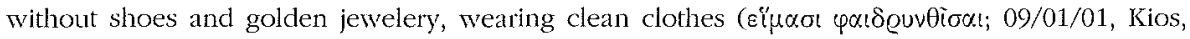
1st cent. AD).

Grave cult and eschalology: Many funerary epigrams allude to eschatological ideas and motifs [cf.

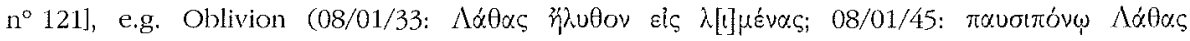

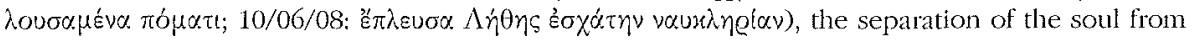

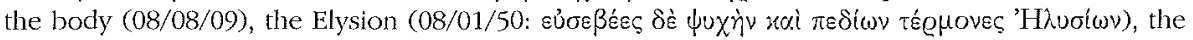

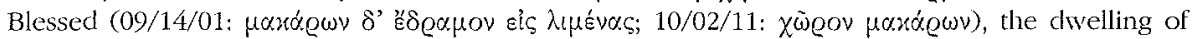

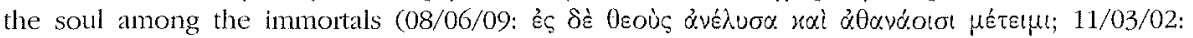




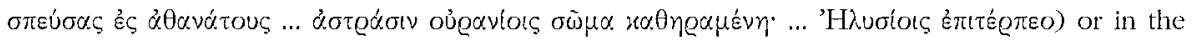

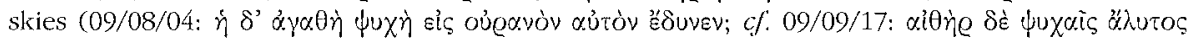

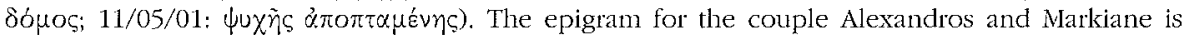
more unusual; "a grave received his bones, his soul was received by the entire fatherland; later, his soul received the soul of his beloved wife Markiane, the grave received her bones" (10/02/03). The epigram for the warrior Mokazis (Nikomedeia, Hellenistic period) alludes to his heroisation and to the idea that even after his death he protected his fatherland (09/06/18:

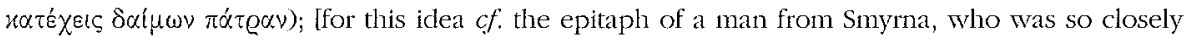
associated with the tower which he had protected in wars, that he had himself buried near it in order to offer his protection even after his death (L. ROBERT, "Hellenica", $R P b 18$ [1944], p. 44-46). An epitaph mentions the fact that a man was buried by the hands of his threptos (08/05/06: $\delta \sigma i \omega \varsigma$

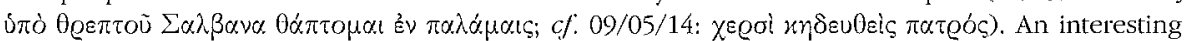

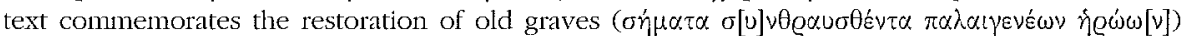
by Loukios (11/07/13, Amaseia). The gravestone of Severus asserts that he still speaks through the

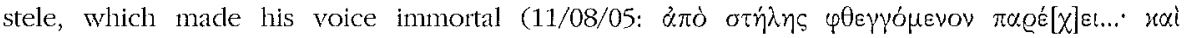

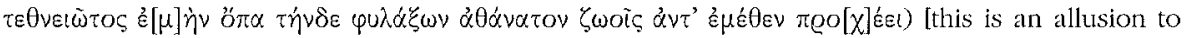
the loud reading of grave inscriptions]. A funerary monument was dedicated to gods (09/05/41). The funerary epigram for a young man urges not to accuse god for his death (09/04/06, Prusa:

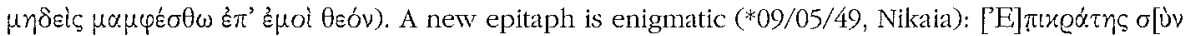

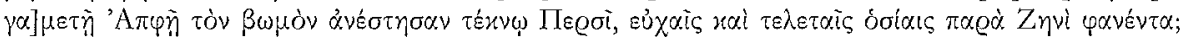
M.-S. translate: "Epikrates mit seiner Gattin Apphe errichten diesen Altar ihrem Kind Perseus, der" mit Gelübden und frommen Ritten bei Zeus erschienen ist"; they assume that the verse expresses the idea that the young man went to Zeus like Ganymedes; [this is plausible, but the dative Пe@oi does not correspond to the accusative pavévta, which seems to refer to the altar; perhaps one should translate "set up the altar near Zeus (i.e., near the statue or temple of Zeus), display-

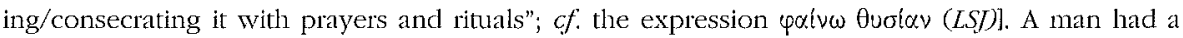
statue of Dionysos erected near his grave in order to be reminded of the symposia he had celebrated during his life $(09 / 06 / 19)$; the epitaph of a woman refers to her prayers to god to die

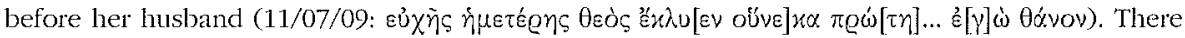
are several funerary imprecations $(08 / 01 / 35,08 / 06 / 06,09 / 05 / 27)$; we single out an unusual

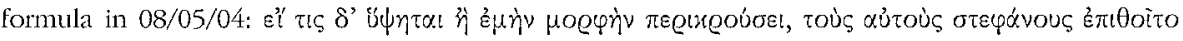

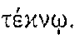

Varia: The epigram for Menophantos, who had been murdered, implores Dike and Zeus to

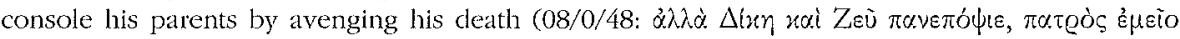

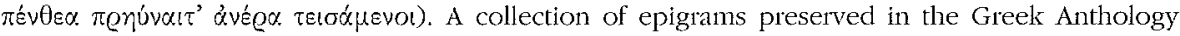
(Anth.Pal. III 1-19) describe the mythological reliefs which decorated a temple in Kyzikos (08/01/11-29). An interesting expression of piety and devotion to the local cults is the epigram of Iulia Hagne, who died abroad, leaving back the god of her fatherland (08/08/09, Hadrianoi: $\theta e o v$

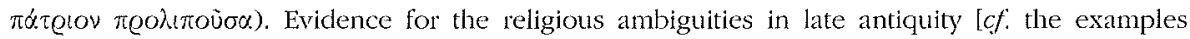
collected under $n^{\circ} 121$ ] is provided by several texts: the epitaph, which was set up by Kyriakos

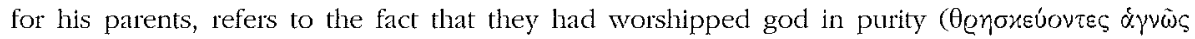

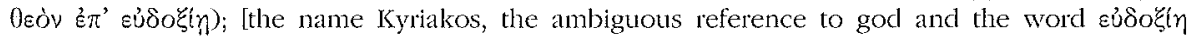
suggest a Christian context]. A Christian woman indirectly refers to her Christian faith (11/10/03,

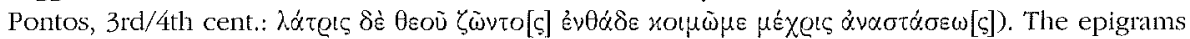
of the governor Iovinus in Therma (11/04/02; 4th cent. AD) exploit pagan themes (Hephaistos, the Nymphs, Charites, Asklepios; $c f$. the epigrams of Marianus in Amaseia: 11/07/01-06). [AC]

121) R. Merkflbach - J. STAuber, Steinepigramme aus dem griechischen Osten. Band 3: Der "ferme Osten" und das Landesinnere bis zum Tauros, Leipzig, 2001: The third volume of the corpus of Greek epigrams [cf: supra $n^{0} 120$ ] covers the material from Baktriane, Media, Armenia Maior, Kappadokia, Lykaonia, Isauria, Galatia, and Phrygia. New texts are marked with an asterisk. Since most of the metrical inscriptions of these areas are funerary epigrams, this material provides information primarily about eschatological ideas; e.g. we find references to the

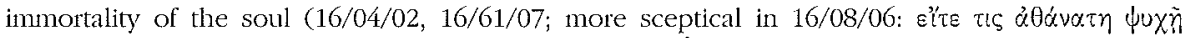

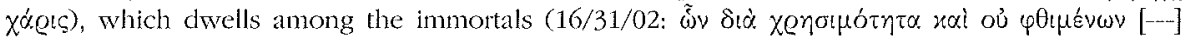




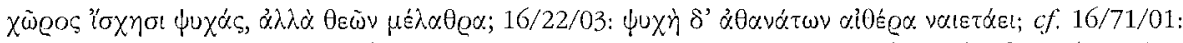

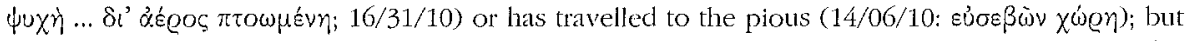
we also find speculations about whether the deceased retain their consciense in the Hades

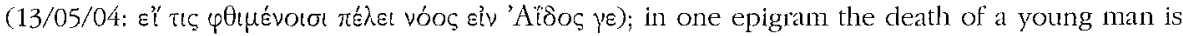
assimilated to the abduction of Ganymedes by Zeus (16/23/06, Aizanoi, AD 247; cf. 16/46/01, Vetissos). The epitaph of a man struck and killed by lightning (*16/34/32, Dorylaion, Imperial period) urges the passer-by: "pass by with pious tongue, not calling me a grave; I am the site of worship of heavenly lightning and fire; the light-bearing torch has purified/consecrated here the

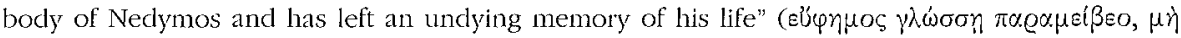

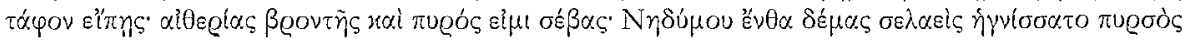

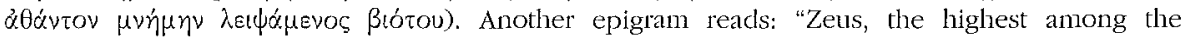
immortals, has called the mortal man from the dead, ordering not to honor the monument of Ploution as a grave, but to honor the merciful conduct of Zeus in this very same site" (ó Beotòv

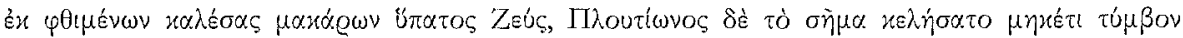

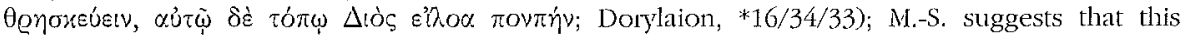
epigram expresses the idea that virtuous persons were taken by Zeus to heaven; for was Ploution struck by lightning and the place where he died and was buried was consecrated to Zeus (Kataibates)?]. The inscriptions of Phrygia are of particular interest in this respect. As we can infer from symbols, onomastics, and content, many texts concern crypto-Christians (before AD 311), Christians, members of Christian sects (e.g., Montanists), or persons influenced by Christianity; nevertheless, they use pagan or ambiguous themes, words, and expressions, and thus they are an interesting source for the interpenetration of ideas among the Christians, the Jews, and the worshippers of the traditional gods. A Montanist epigram, e.g., refers to the Erinyes, Acheron, and Plouton (16/32/04) [cf. EBGR 2000, 193], the epitaph of bishop Pientios to the eating of ambrosia (16/43/06). The epigrams in the family grave of Aurelius Trophimos (Appia or Soa, c. 300-350 $\mathrm{AD}$ ) show the co-existence of different religious ideas within the same family; the earliest epigram (for Trophimos) sketches a gloomy picture of the underworld, whereas that of his granddaughter Anmia mentions the fact that she had been baptised on her death-bed and had joined the sect of the Novatiani (16/31/93). In many cases the attribution of a text to a particular religious group is difficult, as, e.g., in the case of a woman to whom "the god who reigns in heaven" ( $\theta \varepsilon \dot{c}$ c oủeavị $\varepsilon v \beta \alpha[\sigma i \lambda \varepsilon(\omega v])$ had given prudence (16/06/02, Eumeneia, early 3rd cent. AD) or another woman to

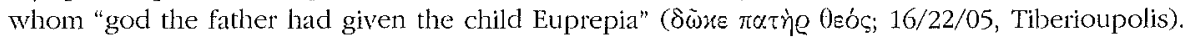
Other epitaphs refer to the immortality of the creator god (16/31/13, Appia or Soa: oủdeis $\gamma \dot{\alpha} e$

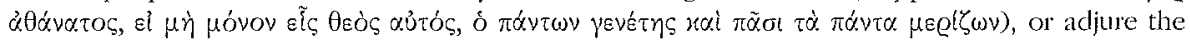
passer-by by the name of god not to violate the grave (16/31/14, 16/31/85, Appia or Soa: tòv Acóv

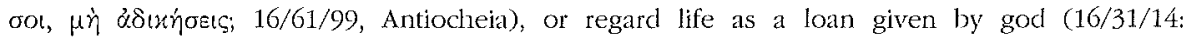

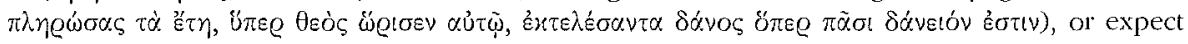

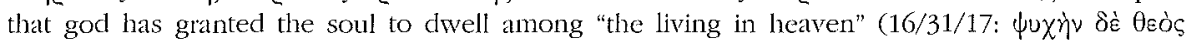

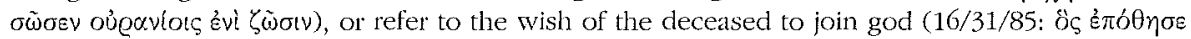

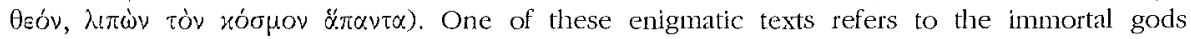

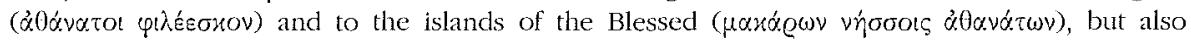

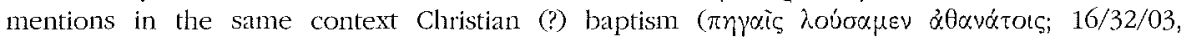
Kotiaion). This phenomenon can be observed also in other areas, besides Phrygia: Christian epitaphs allude to the traditional theme of the Blessed (14/04/03), or even use traditional funerary imprecations (14/06/17). The assimilation of the Christian vocabulary to that of the pagan cults

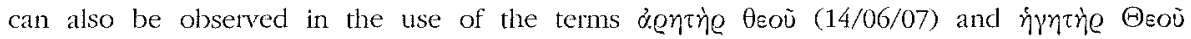

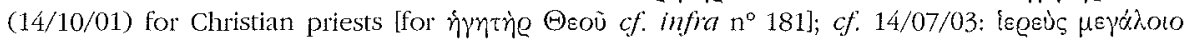

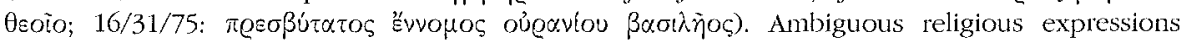

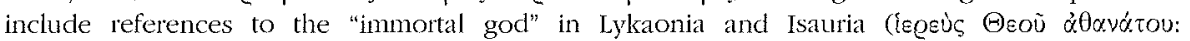

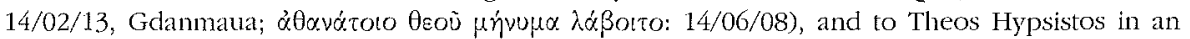
epitaph decorated with crosses, but dedicated to an iegev̀ $\theta \varepsilon o \tilde{~ s \psi l i \sigma \tau o u ~(14 / 07 / 04, ~ I k o n i o n, ~}$ undated).

With regard to grave cult we point to an epigram which urges the passers-by to place a rose or another flower on the grave of Athenais (12/02/01, Wank in Kappadokia, Imperial period). A 
woman erected the grave altar for her husband, "so that he will be among the future mortals"

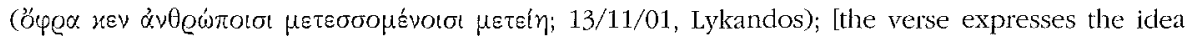
that the perfomance of the grave rituals on the altar continues the communication between living and dead]. An epitaph urges the passers-by to pray for the son of the deceased couple (16/04/03:

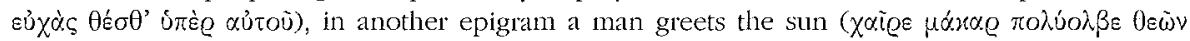
'Yr $\pi \varepsilon e$ éove $\lambda \dot{\alpha}(y \pi \omega v)$ and prays that his fatherland celebrates the harvest festival and is granted

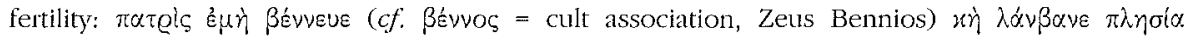

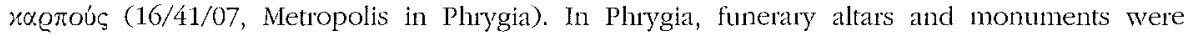
dedicated to Zeus (16/34/21, Dorylaion, 1st/2nd cent.; *16/36/99, Midaion, to Zeus Bronton; $16 / 46 / 01$, Vetissos, to Zeus Theos Megas). Many funerary imprecations are formulated in metrical form $(14 / 01 / 01,14 / 02 / 14,14 / 06 / 97,14 / 07 / 06-07,16 / 06 / 04,16 / 23 / 09,16 / 25 / 02-03,16 / 31 / 96$, $16 / 31 / 99,16 / 32 / 07,16 / 32 / 12-13,16 / 41 / 11,16 / 43 / 05,16 / 44 / 03,16 / 45 / 10,16 / 52 / 04,16 / 53 / 08$, $16 / 53 / 99,16 / 57 / 98-99)$. We single out only a few texts which were not included in J. STRUBBE,

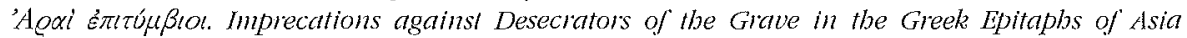

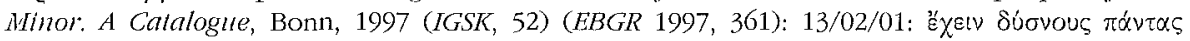

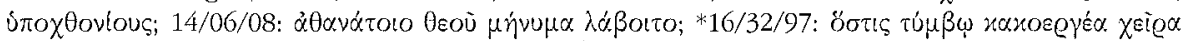

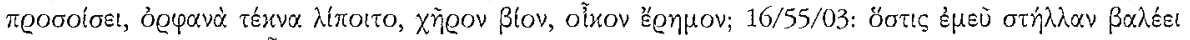

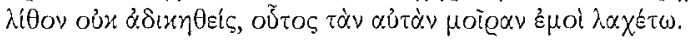

Another major group of texts are dedicatory epigrams (anonymous deity: 16/05/01; Hosion, Dikaion, and Helios: 16/34/02; Meter Theon, Phoibos Hosios, Mes Dikaios, Dikes Ophthalmos:

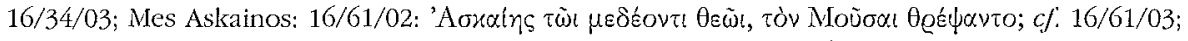
Meter Theon: 16/34/04; Nymphs: 14/06/01; Zeus Alsenos: 16/03/02; Zeus Panhypsistos: 16/44/01). We mention but a ferw: Ti. Claudius Candidus, a general of Septimius Severus, dedicated an altar to Zeus following an oracle of Apollon (13/03/01, Direk Kale in Kappadokia); Aurelius Diomedes, who served many times as envoy of Vasada to Rome, dedicated an altar to Athena thanking her for his safe return ( $\sigma \omega \theta \varepsilon i s ; 14 / 16 / 01$, Vasada); Senekas dedicated an altar to

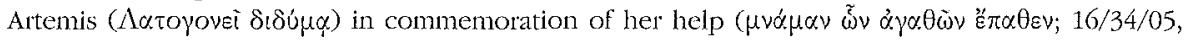

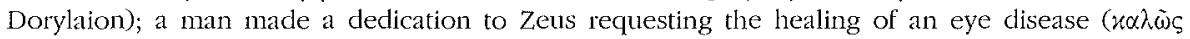

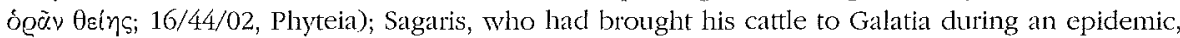

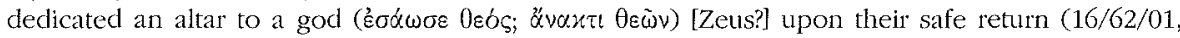
Apollonia Mordiaion); a man carved with his own hands an object made of wood, brought it to

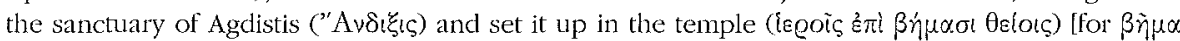
(platform?) see G. PETzL, Die Beichtinschriflen Westkleinasiens, Bonn, 1994 (EA, 22), p. 45 n $\left.^{\circ} 36\right]$

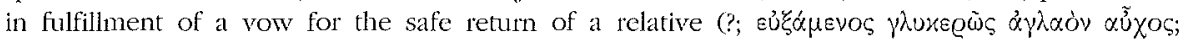
$16 / 41 / 06$, Metropolis); Menestratos made a thanks-giving dedication for his rescue $(\delta ![\alpha \sigma \omega \theta \varepsilon i c])$ to

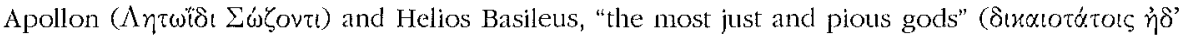
$\delta$ fiotol $\theta[\varepsilon o i c] ; 16 / 55 / 01$, Philomelion). One of the new dedicatory epigrams from Nakoleia (*16/35/01, Imperial period) is a dedication to Helios Titan, to another deity, whose name is not

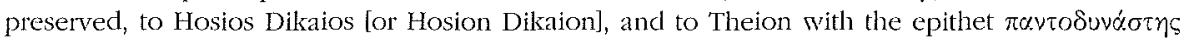
("the divine, which rules everything"); this dedication was made by an anonymous man and

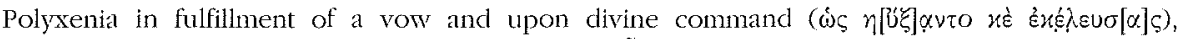
presumably after winning a victory (in a lawsuit?; ñर

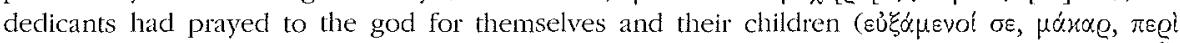

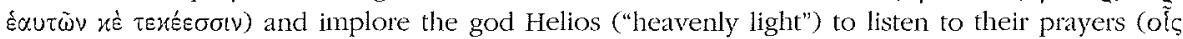

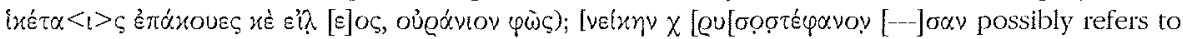

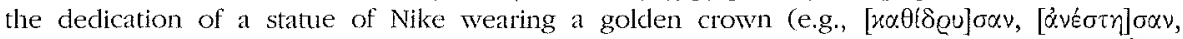

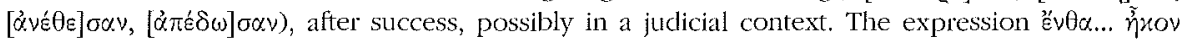
$x \alpha l+$ a verb of dedication ("they came here and dedicated") underlines not only the act of

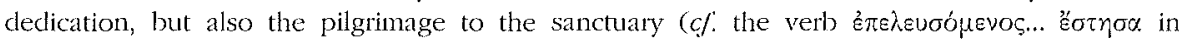
$16 / 41 / 06$ ). It also is interesting to note that, although the dedication was made to several

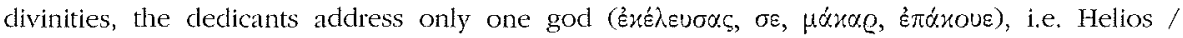
Apollon; for the perception of Hosios Dikaios as intermediaries between the humans and a more distant god see EBGR 1992, 185; 1998, 207]. 
Divination is represented through two metrical oracles from Klaros. In one of them Apollon advises the citizens of Ikonion to set up a statue of Hermes and Thesmos on either side of a statue of Ares (with his hands bound?) in order to avert evil (14/07/01, Ikonion, 1st cent. BC), in the other Apollon requests the setting up of an altar of Apollon, who protects fertility (16/31/01, Appia or Kotiaion). An epigram on the grave of a couple, set up by a son or a daughter, informs

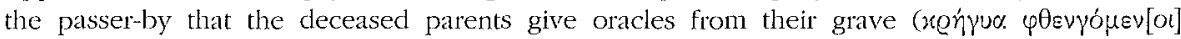

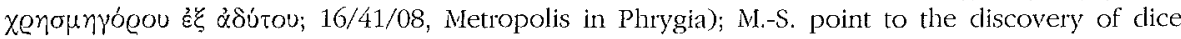
oracles in graves; [a closer parallel is an inscription in Lydia (TAM V.2, 1055) which records the declication of an altar for a clead priestess by the association of mystai; the deceased priestess was believed to have divinatory powers; people seeking the truth should pray in front of her altar, in order to receive an answer by means of visions, either by day or night]. Zosimios, possibly a Jew

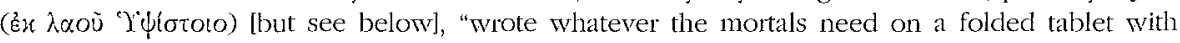

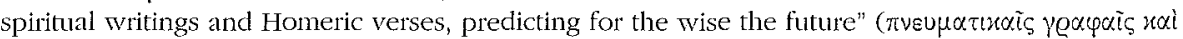

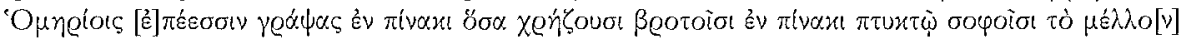
ú $\pi \varepsilon([\pi \dot{v} v]$; M.-S. suggest that the man was in a modest way a "prophet" (16/41/09, Phrygia, 3rd cent. $\mathrm{AD}$ ); [the reference to Homeric verses points to another direction, i.e. the composition of a Homeromanteion, such as the one contained in P.Lond. I 121 (4th/5th cent.): verses of the Iliad and the Odyssey were arranged in groups of six verses which served as answers to oracular

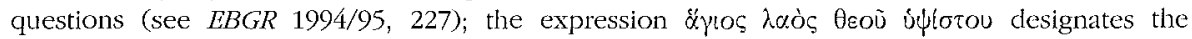
Christians in an epigram from Hadrianoi (MRRKEl.BACH - STAUBER, Steinepigramme II 08/08/13)]. The inscription dossier concerning the high priest of the emperor cult Epitynchanos (Appia, AD

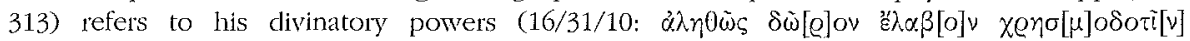
$\alpha \lambda \eta[\theta \varepsilon i] \alpha \varsigma)$.

Among the other texts we single out the Delphic sayings inscribed in the temenos of Kineas, the founder of Alexandreia Oxiana (12/01/01, c. 300 BC), the hymn of Herodoros to Helios (12/03/01, Susa, 3rd/2nd cent.) [to be added to the collection of FurLEY-BREMER, supra $\mathrm{n}^{\circ}$ 62], the criticism of

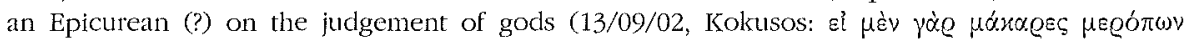

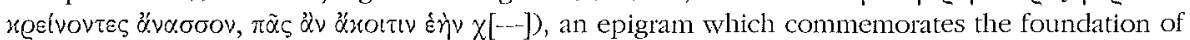
the agon Herakleia by Pasikrates (14/16/02, Vasada, 3rd cent. AD), the grave altar of a priest of Apollon who had the same name as the god that he served (15/03/01, Pessinous, Imperial period), a mythological poem which refers to the metamorphosis of Ganymedes into a star and the foundation of Sebaste in Phrygia (16/01/01, Sebaste, 3rd cent. AD), a funerary epigram which praises friendship and honesty, written by a pious man who had entrusted himself to god

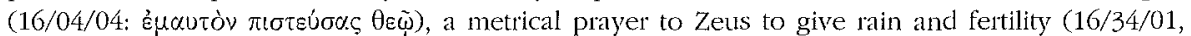
Dorylaion, $\mathrm{AD} 75$ ), an honorary epigram for Demetrios, high priest of the emperor cult in Asia,

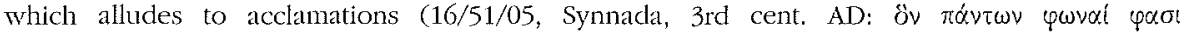

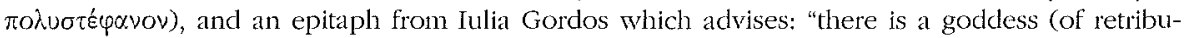

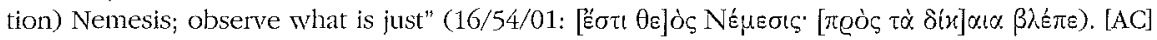

122) R. MERKElBACH - J. STAUbER, "Epigramme aus Sinope und Amaseia", EA 33 (2001), p. 69-83: M.-S. (re)publish 8 epigrams from Sinope and Amaseia. Among the already known texts we single out the mention of a cenotaph ( 1 = PEEr, GV 1562 a; Sinope, 3rd cent. AD), the

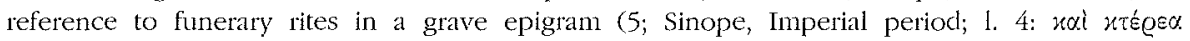
$x \tau \dot{e}(\sigma \alpha \nu)$, and a fragmentary text, which seems to be a poetic description of Christian paradise,

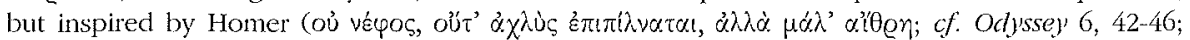
Amaseia, 4 th $/ 5$ th cent.) [cf. supra n 88]. [JM]

123) R. Merkelbach - J. Stauber, "Ein paegniarius", EA 33 (2001), p. 79 [BE 2002, 433]: M.-S. point out that the retiarius Philokynegos from Macedonia, known from an epigram in Amaseia (SEG XXXIX $1340=$ MERKELBACH - STAUBER, Steinepigramme II 09/09/01) was also a

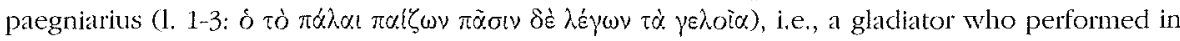
the arena as a joker in addition to his engagement in combats. [JM] 
124) M. Mrrković, "Katagraphe and the Consecration of Children", in Mélanges d'bistoire et d'épigraphie offerts à Fanoula Papazoglou par ses élèves à l'occasion de son quatre-vingtième anniversaire, Beograd, 1997, p. 1-33: The consecration of slaves and children to gods is attested in many inscriptions both for the sanctuary of Apollon Lairbenos in Phrygia and for Macedonia [cf. EBGR 2000, 155 and 169]. In this thorough and well documented

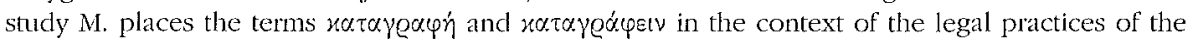
Imperial period. In addition to many remarks with regard to individual texts, $M$. underlines the official nature of the deeds of consecration and their legal and fiscal consequences, showing that the term $x \alpha \tau \alpha \gamma \varrho \alpha \varphi \eta$ primarily documented the conveyance of the names of the dedicated persons from one tax-list (that of the father or the master) to another (that of the temple). The relevant documents were a public guarantee of the god's right over the dedicated children and slaves. M. proposes to compare the dedicated slaves and children with the coloni adscriptici, i.e., free persons bound to the temple and not entered into the tax-rolls in their own right, but under the name of the landowner. [M.'s analysis of the legal consequences of the consecration of persons is well founded; one should not, however, underestimate the religious background of these texts, for which see infira $n^{\circ}$ 153]. [AC]

125) H. MüLLER, "Makedonische Marginalien", Chiron 31 (2001), p. 417-455: M. presents an improved text of an honorary inscription from Beroia (I.Beroia 84, 2nd cent. AD) for Annia Tydane, wife of Veiento; her statue was erected by the synedroi of the Makedonian Koinon during the term of office of (T. Flavius) Kassandros as high priest of the Koinon (cf. I.Beroia 106). A new inscription from Augusta Traiana ( $E B G R$ 2000, 138; SEG XIIX 885, 2nd/3rd cent.) honors C. Iulius Terres, priest of Zeus Sabazios and member of a prominent family in Thrace; $M$. discusses the prosopography of this senatorial family. [JM]

126) D. Mullifz, "Notes d'épigraphie delphique. VIII. L'empereur Claucle, témoin et archonte à Delphes", BCH 125 (2001), p. 289-303: Ed. pr. of three Delphic inscriptions (c. $\mathrm{AD}$ 45-54): 1) A sacred manumission in the sanctuary of Apollon Pythios mentions the priests of Apollon Nikandros and Melission among the witnesses. 2) An apolysis (release of the manumitted slave from the obligation to serve the master) mentions among the witnesses the god, the emperor Claudius, whose stay in Delphi is thus attested for the first time, and the priests of Apollon Nikandros and Melission. 3) An apolysis took place under the archonship of emperor Claudius. M. disusses the close relations of Cladius to Delphi (cf. F.Delphes III 4, 286). [JM]

127) L. MuÑoz Delgado, Léxico de magia y religión en los papiros mágicos griegos (Diccionario griego español, Anejo V), Madrid 2001: M. presents with the collaboration of J. Rodríguez SOMOLINos a very useful lexicon of the terms that appear in the Greek magical papyri. $[A C]$

128) G. NAChTERGAEL, "Sceaux et timbres de bois d'Égypte. II. Les sceaux de grand format", $C E 76$ (2001), p. 231-257 [BE 2002, 518]: N. republishes three wooden seals with

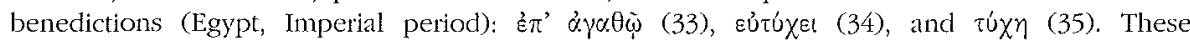
inscriptions reinforced the protective function of the sealing. [AC]

129) I. NICOLAOU, "Inscriptiones Cypriae Alphabeticae XXXIX, 1999", RDAC (2000), p. 299-304 [BE 2002, 496; SEG L 1373-1376]: Ed. pr. of two dedications to Kyrios Theos Hypsistos made by two related persons (father and son) and written on cippi of the common funerary type (1-2; Limassol, 3rd cent. AD). For this reason $N$. interprets them as funerary dedications made in the name of the deceased [but see infira ${ }^{\circ} 130$ ]. N. regards the epithet Kyrios, which was hitherto unattested for Theos Hypsistos in Cyprus, as the result of Christian influence, and suspects that the two dedicants may be crypto-Christians; [xúptos/xugla are extremely common epithets for pagan gods (see, e.g., the indices of $E B G R$ 1996-2000), which have nothing to do with Cluristian influence; $c f$. R. TYBout, SEG L 1374]. [AC]

130) I. NiCOLAOU, "Inscriptiones Cypriae Alphabeticae XI, 2000", RDAC (2001), p. 291298 [BE 2002, 490]: Ed. pr. of a dedication to Theos Hypsistos "on behalf of my son Maros in fulfillment of a vow" (1; Limassol district, 3rd cent. AD). [The text is written on a cippus; N. 


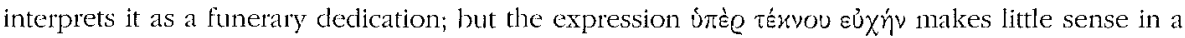
funerary declication; cf. J.-B. CAYLA, BE 2003, 490 and 496]. Ed. pr. of a dedication to Theos Hypsistos in fulfillment of a vow ( 2 ; Limassol district, $3 \mathrm{rd}$ cent. AD). N. observes that 20 dedications to Theos Hypsistos are known from Cyprus [cf. supra $n^{\circ} 129$ ]. Ed. pr. of the epitaph of the priest Timon (12; Limassol district, 2nd cent. AD). [AC]

131) NN, "Jahresbericht", $A A$ (2001), p. 689-691: In a report on the excavations in the temple of Zeus Megistos at Qanawat/Kanatha (Syria) a new inscription is mentioned. A member of the council dedicated together with his wife and son the pronaos (meovoiov) to Theos Rabbou (1st cent. AD). [AC]

132) J. NOLLÉ, Side im Altertum. Geschichte und Zeugnisse. Band II, Bonn, 2001 (IGSK, 44.2) [BE 2002, 444, 624]: The second volume of the inscriptions of Side presents 274 Greek and Latin inscriptions, primarily of the Imperial period, as well as 11 inscriptions in the local language and alphabet ( $S$ 1-11) [for a summary of the first volume see $E B G R$ 1993/94, 174]. New

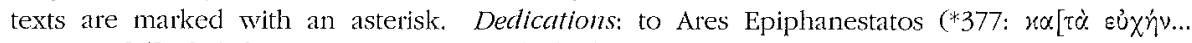

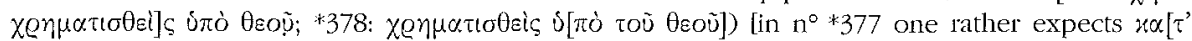

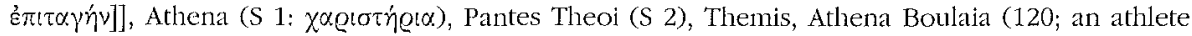
dedicated the statue which he had received as a prize), a Theos (Athena?, 141), an Epekoos Theos (*376), and Zeus Aspidios (p. $6591^{\circ} 18 \mathrm{a}$; an altar). Festivals and agons: The most prominent agonistic festival in Side was the agon Hiera Pythia, an agon hieros oikoumenikos isopythios ekecheirios eiselastikos, founded in AD 243 (134,*143); two metrical oracles concerning the foundation of the agon were inscribed on a gilded altar which was dedicated on the third celebration of the agon (134); the first oracle contrasts bright clothes and a pure mind (ou

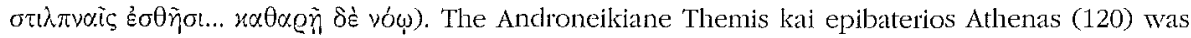
founded by a priest of Themis; $N$. interprets the word $\varepsilon \pi \beta a \tau$ ń placing of the statue of Athena on a ship at the beginning of the season of seafaring; p. 424f.);

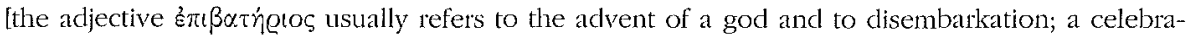
tion at the beginning of the sailing season is plausible, but possibly in connection with the celebration of the periodical advent of divinities]. A related agon, which is more often attested, is the Themis Pamphyliake Touesianeios epibaterios theon Athenas kai Apollonos, founded by Aur. Paioneinos Tousianos who served as agonothetes for life (121-126) [for the founder of an agon who served as agonothetes for life see $E B G R$ 1994/95, 155]. A third agon founded by a private person was the Agon Isopythios Phoibeios in honor of Apollon Theos Patrios Ktistes (129); the

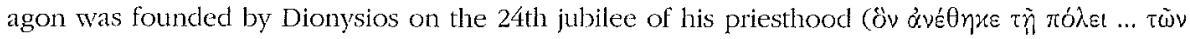

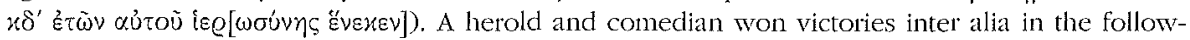
ing agons (130): Mystikos (Side), Isokapitolios (Hermoupolis), Sebasmia (Damaskos), Hadrianeia (Antiocheia pros Daphnen), Agon Eukratous Koinos Pontou Isaktios (Neokaisareia), and Sebereia Peraseia (Kastabala). Other agonistic inscriptions mentions victories in the Nemea (133), and a victory without competition (131) [cf. $\left.\mathrm{n}^{\circ} 43\right]$. A great penataeteric agon was probably connected with the emperor cult (*77). T. Flavius Spartiatikos served as theoros to the Panathenaia (73). Ruler and emperor cult: The cult of Zeus Nikator was possibly connected with the cult of Seleukos I (90). The neokoreia of Side in mentioned in $n^{\prime \prime \prime} 112$ and 158. An honorary inscription attests the rare case of the office of the high priest and priestess of the emperor cult being occupied not by a couple, but by a man and his sister (103). The grave epigram von Romana provides information about the public appearance of the high priestess: her husband, the high piest, "had her carried as a high priestess in the brilliant thymelic competitions, in purple dress,

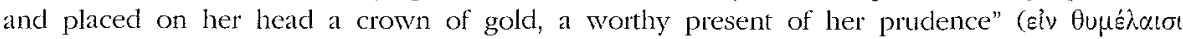

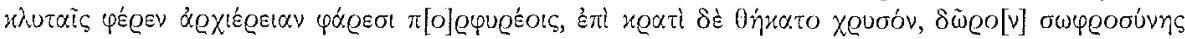

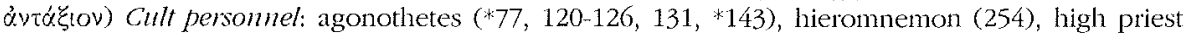
of the emperor cult $(78,81,116,226$; $c f$. high priest pentaetertikos: $70, * 77)$, priest of Apollon (75,

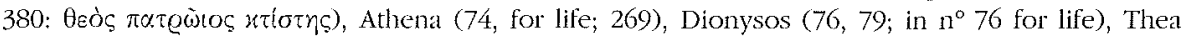
Rome $(70,72,74,76, * 77,79,81, * 82,83-85, * 88-89,157, * 374)$, Themis (120, for life), Theoi Megaloi (i.e., the Dioskouroi or the Egyptian gods; 90), Zeus Nikator (90), the Egyptian gods (74:

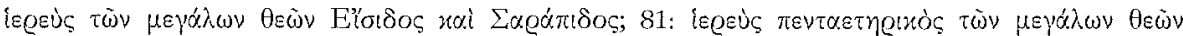

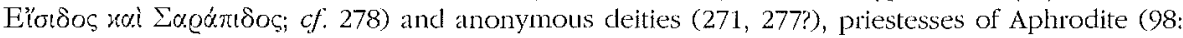




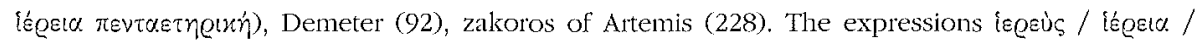

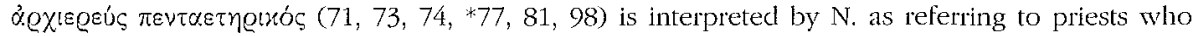
served for a period of five years (p. 362 and 388), i.e. from one celebration of a pentaeteric agon

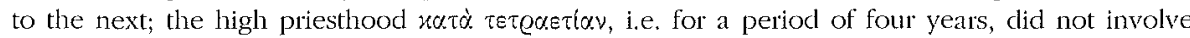
the expenses for the celebration of agons (p. 394); [one should not exclude an alternative

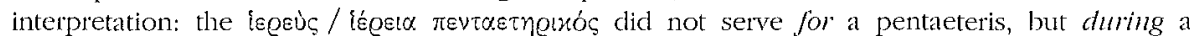
pentaeteris, i.e. in the year of the celebration of the pentacteric festival; cf. the duoviri quinquennales who did not serve for five years, but on the fifth year, i.e. the year of a census]. Several persons accumulated priestly offices (71: high priest, priest of Apollon and Poseidon Asphaleios; 73: priest of Thea Rhome and high priest; 74: priest of Thea Rhome and the Egyptian gods). A priestess of Athena for life was the daughter of a high priest and wife of a priest of Thea Rhome (74). Eschatology: A funerary epigram rejects the belief of an existence after death: "some claim that after the great trouble of life the souls of the deceased fly in the wide air; this is a myth"

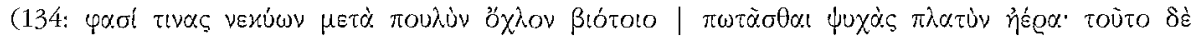
$\mu \bar{u} \theta 0 \varsigma$ ). Varia: One of the districts of the city was named after an altal of Zeus (107: BwHeitat Znquó) [for districts named after gods cf' the district of Herakles in Kamarina in SEG XXXTX 1002);

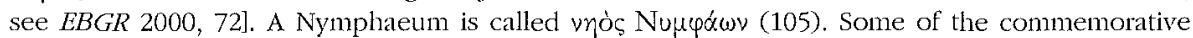
inscriptions set up by the demiourgoi and priests of Thea Rhome refer to the fortunate events

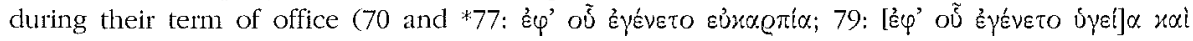
Eủx.ería]). An epitaph regards poisoning or magic as the cause of the (obviously unexpected) death of a woman (206: $\pi \varepsilon \varphi \alpha Q \mu \alpha \varkappa \varepsilon u \mu \varepsilon v \eta)$. An metrical inscription invokes the apottopaic powers of Herakles [c/. infira $\mathrm{n}^{\circ}$ 169]. [AC]

133) D. Nuzzo, "Amulet and Grave in Late Antiquity: Some Examples from Roman Cemeteries", in J. Pearce - M. Mulett - M. Struck (eds.), Burial, Society and Context in the Roman. World, Oxford, 2000, p. 249-255: Although the use of amulets and attempts to communicate with the dead were often repressed both by church and state in late antiquity, this practice continued. N. collects examples of inscriptions and objects in Roman cemeteries (4th-5th cent.) which show the persistence of the belief in evil spirits and the use of apotropaic formulas (e.g., ICUR IV 12090: I $\alpha \omega$ ), magic signs and images (e.g., 'ring signs', Solomon the Rider, Bes Pantheos, representations of Egyptian deities, a male figure with a snake-head, Gorgon's heads, etc.; e.g., ICUR 6190, 19893 b, 20332 b) and objects (amulets of Solomon, bronze bells, masks, nails, animal teeth) (on magic in late antiquity see also J. ENGEMANN, "Anmerkungen zu philologischen und archäologischen Studien über spätantike Nagie”, JAC 43 (2000), p. 55-70; J. WORTLEY, "Some Light on Magic and Magicians in Late Antiquity", GRBS 42 (2001), p. 289-307]. []M]

134) F. Onur, "The Lamp-stand Offerings of Primipilarius Flavius Bassus to Apollo Patroos in Patara", EA 33 (2001), p. 169-173 [BE 2002, 412]: O. publishes the dedicatory inscription of the primus pilus Flavius Bassus to Apollon Patroos (1st/2nd cent.) on a triangular base found in 1994 during archaeological excavations at Patara. Apparently a lamp offering in

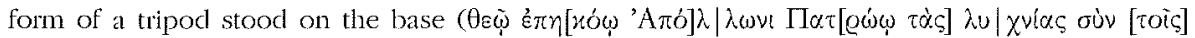

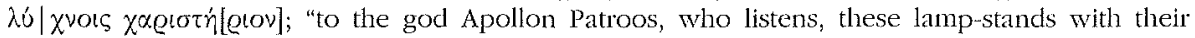
lamps, as a thanksgiving). [JM]

135) Th. OzIOL, "Une inscription funéraire au Musée de la Fondation Piéridès à Larnaka", RDAC (1999), p. 255-258 [SEG XIIX 1966]: O. republishes a very interesting funerary epigram (PEEK, Griechische Versinschriflen 1201; Kition, 2nd cent. AD), in which a

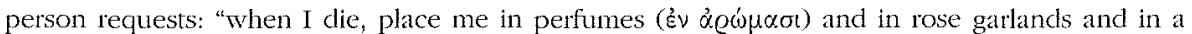

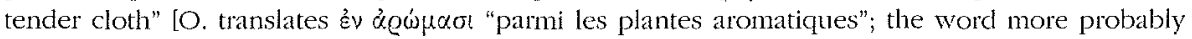
alludes to the anointment of the corpse); in the last fragmentary lines the anonymous persons refuses to accept other funerary gifts (incense?, safran?; $c f . I G$ XII Suppl. 152). This is a unique case of a funerary epigram in which a person uses the future form with regard to his own death ("when I die"). The offering of rose garlands should be distinguished from the Roman custom of thodismos/rosalia (placement of roses on the grave). The instructions for this burial suggest a Semitic origin of the deceased (cf. Nou. Test. Matth. 27, 59-60; Marc 16, 1). [AC] 
136) O. PALAGIA, "A Gymnasiarch's Dedication and the Panathenaic Torch-Race", in Agathos Daimon, p. 403-408 [SEG L 192]: P. associates a relief in the British Museum with the torch-race of the Panathenaia ( $f f . I G I^{2}$ 3019), identifying the altar on the relief as that of Athena Polias and the male figure wearing the spiked crown as the eponymous hero of the victorious tribe. The relief was dedicated by a gymnasiarchos, whose tribe had won (IG $\mathrm{II}^{2} 2974$, c. 350325). The other known dedicatory reliefs concerning torch-races were dedicated after ephebic victories at the Bendidia and the Nemesia. [JM]

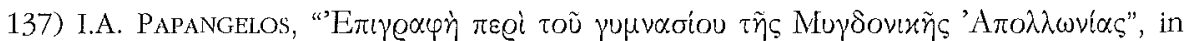
Synedrio Epigraplikikes I, p. 111-114 [SEG L 572]: Ed. pr. of an inscription which records the dedication of a gymnasium to Zeus Soter, Hermes, and Herakles in Apollonia (Mygdonia / Macedonia, 106 BC) [briefly reported in EBGR 2000, 1]. The dedicator, the Roman Marcus Lucilius, had settled in Apollonia, where he was known to the natives under the Greek name Demetrios. [The cult of Zeus Soter in Hellenistic gymnasia is very rare; the only other known attestation is SEG XIVI 1721, 1. 42 (Xanthos)]. [AC]

138) P. PARKFr, "Theophoric Names and the History of Greek Religion", in Greek Personal Names, p. 53-79. The significance of theophoric names for the history of Greek religion is summarized by $P$. He discusses inter alia the avoidance of names deriving from powers associated with the Underworld, the rarity of names deriving from Hephaistos and Poseidon,

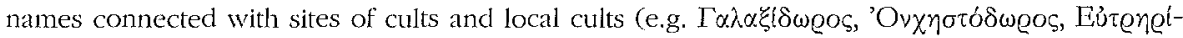

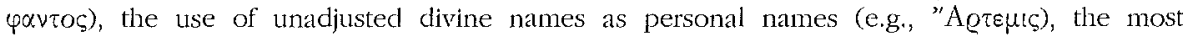

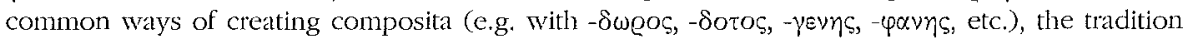
of names within a family, the possible reasons for the selection of theophoric names, the distribution in connection with gender and social status, the translation of non-Greek theophoric names, and the significance of theophoric names as indicators of the popularity of cults. [AC]

139) R. PARKFr - D. OBBinK, "Aus der Arbeit der 'Inscriptiones Graecae'. VII. Sales of Priesthoods on Cos II", Chiron 31 (2001), p. 229-252 [BE 2002, 31, 321]: Ed. pr. of six Koan inscriptions (Greek text, English translation and commentary) which concern sales of priesthoods [cf. EBGR 2000, 151; SEG L 766; see now also H.-U. WIEMER, "Käufliche Priestertümer im hellenistischen Kos", Chiron 33 (2003), p. 263-310]: 1) A fragment concerns the priesthood of the Symmachidai (c. $200 \mathrm{BC}$ ). The main problem of this inscription is the identification of the

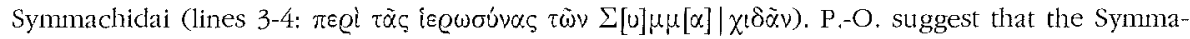
chiclai were not gods or heroes, but a gentilician group, by whose name a particular cult came to be known. The inscription stipulated that the poletai were to sell the priesthood (lines 5-6: toi

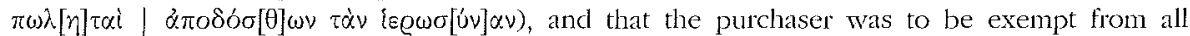

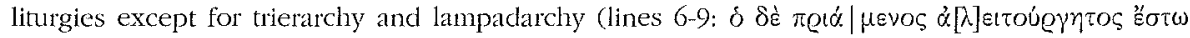

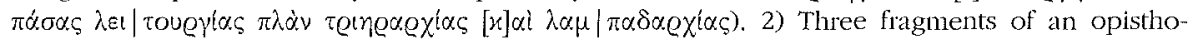
graphic stele found in the Asklepieion concern the priesthood of an unknown deity, perhaps Asklepios (c. $280 \mathrm{BC}$ ). The inscription regulates that the purchaser of the priesthood should be exempt from all liturgies except trierarchy and lampadarchy (A.1-2: xai $\lambda \varepsilon i \tau o v e \gamma(\alpha) v \pi \lambda \dot{\alpha} v$

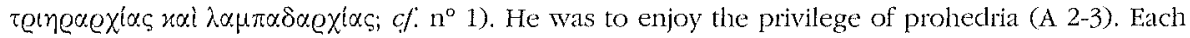
year he should sacrifice to Dionysos a full-grown victim during the Dionysia, for which he was to

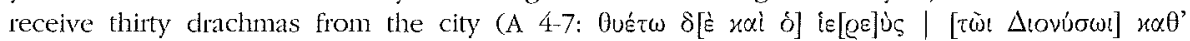

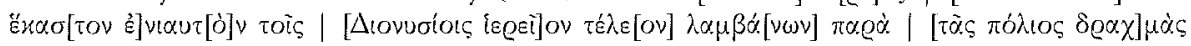

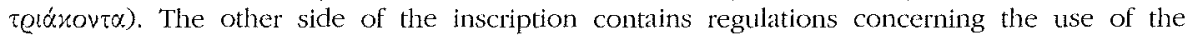
money from the sale of the priesthood. The money should be spent for the builcling of the public

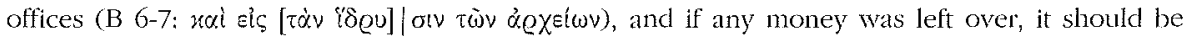

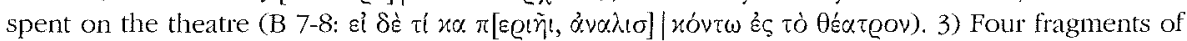
a marble stele found in the Asklepieion deal with the priesthood of Asklepios (1st cent. BC). The first eleven lines regulate sacrificial perquisites and fees. Depending on the sacrificial victim, a payment was to be made to the cash box of Asklepios. The priest was allowed one third of the

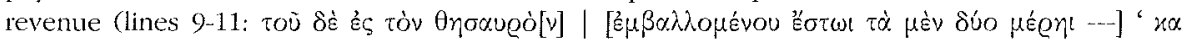

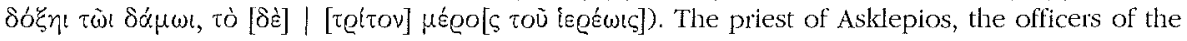
god's bank, and the prostatai were to possess a key for the building of a thesauros in the 
Asklepieion (lines 11-13). Lines 16-31 regulate the duties of the priest of Asklepios: the lighting of the altars, the burning of incense, the daily opening of the temple, the authority to penalize anyone behaving in a disorderly way, and preventing the use of the precinct as a pasture. Any animal found grazing in the sanctuary was to be sacrificed to the god. In lines 31-33 some sanctions against proposals to misuse the god's funds are listed. Upon the sale of the priesthood

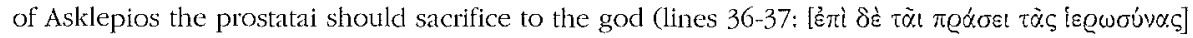

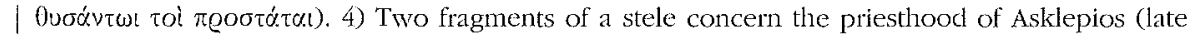
2nd or early 1 st cent. BC). This inscription preserves fragments of a text very similar to lines 4-11 and 14-22 of the aforementioned inscription. 5) A small fragment of grey marble concerns the priesthood of an unknown god (2nd. cent. BC). P.-O. suggest identifying this fragment as part of the section of the siayeapó about priesthoods, which concerns sacrifices (the clause "let sacrifice be performed by"). 6) P.-O. present the Greek text of the last 20 lines of the inscription concerning the priesthood of Hermes Enagonios. In lines 69-82 different sacrifices to Hermes are mentioned; they were to be performed by the stratagoi, the winners of the stephanites agon, and the paidotribai. [JM]

140) R. Parker - D. ObBink, "Aus der Arbeit der 'Inscriptiones Graecae'. VIII. Three Further Inscriptions Concerning Coan Cults", Chiron 31 (2001), p. 253-275 [BE 2002, 322]: Ed. pr. of three inscriptions concerning the sanctuary of Apollon at Halasarna and the festival of the Asklepieia. 1. Two fragmentary decrees of the deme of Halasarna concern a subscription for the quick completion of Apollon's temple, in order that "the completed work on the roof and the door may not be in danger of being spoilt through further delay; and in order that not only the city may be seen to have been actively involved in construction of the temple, but also the god, from the funds that he has, and individuals willing to make pledges for this purpose, and the rites in the shrine may be conducted with more magnificence on completion of the temple" (c. $200 \mathrm{BC}$ ). Side A of the opisthographic stele regulates the supervision of the funds

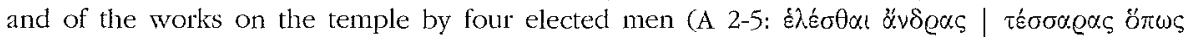

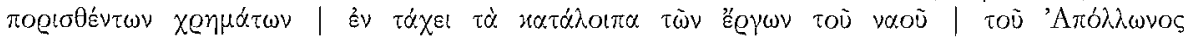
$x \alpha \tau \alpha \sigma \kappa \varepsilon v \alpha \sigma \theta \tilde{\eta})$. On completion of the temple the rites in the shrine should be conducted with

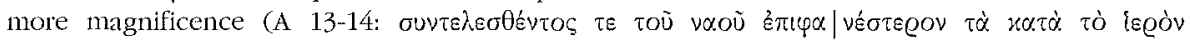

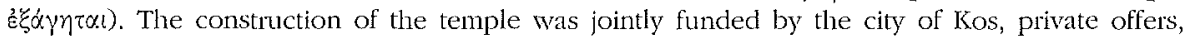
and the treasury of the god; the god tras involved in the funding of his own temple, since the neopoiai were to pay 2000 drachmai to the elected men from the funds of the god (A 15-17:

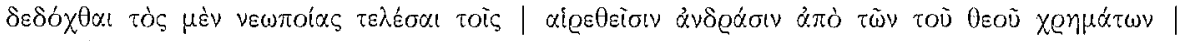
$\delta \varrho \alpha \chi \mu \alpha{ } \mathrm{XX})$. Money was also collected from private subscriptions made both by citizens and by resident aliens. The pledges were to be made within a year at the deme's meetings. The pledged money was to be paid in three installments. The names of the donors [and of the elected men] were probably inscribed - together with the rest of the decree - on the lower part of the stele (now lost). According to the surviving end of the second decree, if any remaining money (after the completion of the temple) was to be given by the commission of four men to the neopoiai and from them "to the epimenioi for the tribes, just as hitherto they used to give for the two days." These two days were the days of the festival of the Pythia. Side B regulates that atter the completion of the temple the money left was to be given to the neopoiai (B 2-4: $\sigma u v \tau \varepsilon \lambda \varepsilon \sigma \theta \varepsilon v \tau \omega \nu$

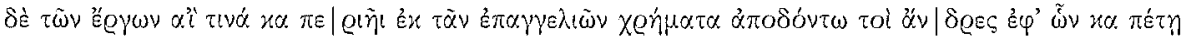
vatóac). 2. A small fragment of a decree concerns the sanctuary of Apollon in Halasarna (175$100 \mathrm{BC}$ ). The inscription records dispositions of some kind made by Kallis[---] (the current priest

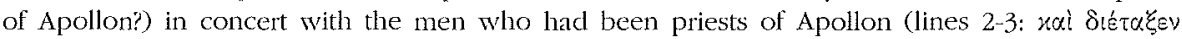

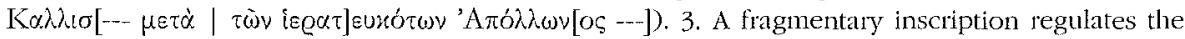
control of a fund established by Teleutias to finance sacrifices to the gods of the Asklepieion (2nd cent. BC). In 1.16 a penteteris is mentioned, which P.-O. identify with the Great Asklepieia. There

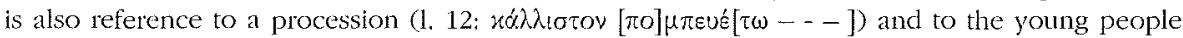

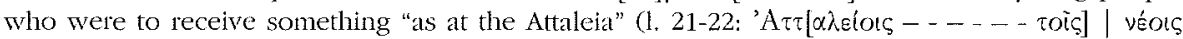
$\alpha \pi \operatorname{l} \delta \delta \delta \delta$ v $\tau \omega)$. Lines $24-27$ refer to the manner in which the capital was to be invested. Sanctions and curses against misuse of the money follow in lines $28-32$. [JM] 
141) S. Pfrea - S. MonTero, "La misteriosa inscripción hispana a Zeus, Serapis y Iao: su relación con la magia y con la teología oracular del Apolo de Klaros", in Miscellanea Gasperini II, p. 711-736: P.-M. republish a stele with the representation of a raised hand and an invocation of Zeus, Sarapis and Iao (Quintanilla de Somoza, province of León, 3rd/4th cent.

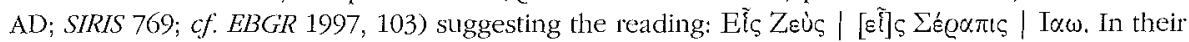
commentary they discuss the magical significance of the raised hand and the significance of this text as evidence for henotheistic tendencies in the Imperial period. The theonyms Sarapis and Iato should not be understood as epithets of Zeus, but as components of a henotheistic triad consisting of Zeus, Sarapis, and Iao. Iao, inspired by the Jewish god, was perceived as a creator god, as an oracle of Apollon Klarios suggests (apud MACrOB., Sat. I 18,18-21; cf. Orph. fragm. 239). $[\mathrm{AC}]$

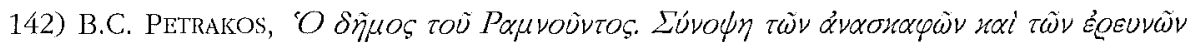

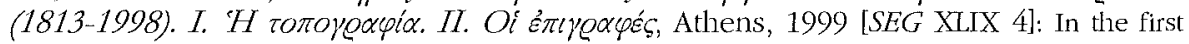
volume of a comprehensive presentation of the results of the excavation in the fortress, the settlement, the sanctuaries, and the cemeteries in Rhamnous (Attika) P. treats among other subjects the cult officials (p. 21f), the altars and dedications in the fortress (p. 94-100), the sanctuaries of Hermes (p. 108-110), Heros Archegetes (p. 117-119), Aphrodite Hegemone (p. 131134), Nemesis (p. 187-296), Amphiaros / Amphieraos (p. 307-319, the hero Aristomachos (p. 312f.), a possible Thesmophorion (p. 320-322), the cults of Hermes (p. 323f.), Dionysos (p. 324327), Zeus Soter and Athena Soteira (p. 327-329), Demeter and Kore (p. 329), Kybele, Attis, and Agdistis (p. 330-332), and the performance of sacrifices (p. 424). The second volume is dedicated to the presentation of the epigraphic finds ( 400 inscriptions and graffiti; the few new texts are marked with an asterisk).

Sanctuaries: The sanctuaries of Dionysos $(1,8,17, * 58)$, Nemesis $(10,13,15,17, * 58,63, * 64)$, and Aphrodite Hegemone in Rhamnous $(32,35)$ and the sanctuary of Soter (i.e., Poseidon Soter) in Sounion (20) are mentioned as the places where public documents and images of honored persons were set up. Many inscriptions concern the most important sanctuary, that of Nemesis. An honorary decree for the general Epichares refers to building activities in the sanctuary of Nemesis (3); another honorary decree for a general seems to imply the use of the Nemesion for defence purposes during a war $(18$, c. 235 BC) [but $c /$. the doubts expressed in the review of $\mathbf{J}$-C. COUVENHES - J.-C. MORETTT, Topoi 11 (2001) [2003], p. 767-784: "le rôle joué par le sanctuaire comme arsenal et pas seulement comme lieu de dédicace reste mal connu"]. The goddess owed land, the leasing of which is regulated by a document $(180,339 \mathrm{BC})$; the fragmentary end of text seems to be a cult calendar which mentions sacrifices (?) to Apollon Lykeios, Apollon [---], Zeus Herkeios, and Artemis or Themis (1. 88: [--] $] \mu \delta t]$. Evidence for the finances of the sanctuary are also provided by a lead tablet listing amounts given to the hieropoioi $(181,6$ th $/ 5$ th cent.) and a stele with the account of the sacred money of Nemesis (182, late 5th cent. BC). Three boundary stones - of a temenos (183) and a sanctuary $(184, * 185)$ - should be associated with the sanctuary of Nemesis, two others delimitated the precinct (iggd $\alpha \dot{u} \lambda \dot{\eta}$ ) of Heros Archegetes (79,*80, 4th/3rd cent.). A woman was honored for her piety towards the goddess (Nemesis; 162).

Dedications: Among the many dedications (74-166) we mention only those, which identify the divinity: Amphieraos, sometimes associated with the healing hero Aristomachos $\left({ }^{*} 169\right.$; Amphiaraos: 172, 175-176, 178; Amphieraos Aristomachos: 171; Heros Tatros: 168; Heros Iatros Amphieraos: 173; Heros Iatros Aristomachos: 170), Aphrodite (118), Demeter and Kore (106, 145),

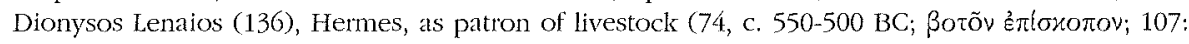
a hermaic stele), Heros Archegetes (77, 81-82), Meter Theon, Sarapis and Isis (155), Themis and Nemesis $(75-76,120,133,150-151)$, Nemesis $(86,90,121,127,159,163,164)$, Themis (122), Zeus Soter and Athena Soteira (146, 148-153). Among the dedicated objects we single out a bronze wheel (76), $\alpha \gamma \alpha \lambda \mu \alpha \tau \alpha$ (77-78), and a helmet (86); two dedications were made in fulfillment of

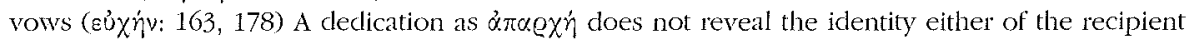

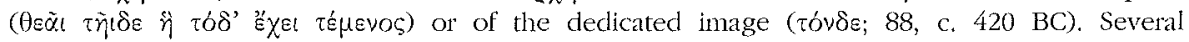
dedications were made by the victorious teams in torch-races of ephebic agons (98), of the Ptolemaia, which were founded in 224 BC $(144,148)$, and of the Diogeneia, founded in 229 BC $(146,148)$. 
Rituals and festivals: The offering of sacrifices is a common theme of many texts. In the dedication of a statue of Polydeukion, the foster child of Herodes Atticus, Herodes refers to the

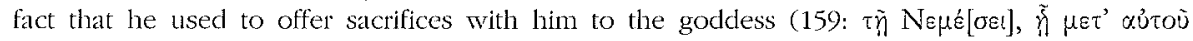

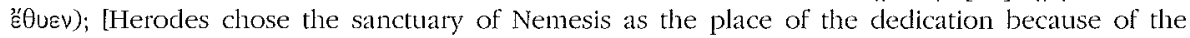
memories associated with this place; this a very interesting piece of evidence for the perception of sacrifice as the bond which connected two persons and could be remembered as a shared experience]. Honorary decrees for officers mention the performance of sacrifices to the gods and

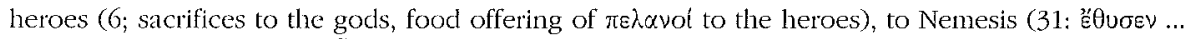

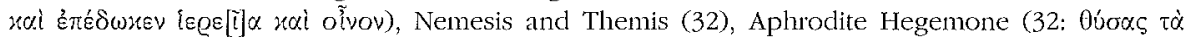
$\dot{\varepsilon} \xi \tau \eta \dot{n} \varrho(\alpha)$, and the other gods $(32 ; c f .38,49-50)$. Of particular interest for the effect of war on rituals is the honorary decree for Dikatarchos (c. $235 \mathrm{BC}$ ), commander of the garrison in Eretria, who "provided sacrificial animals for the sacrifice of the Nemesia and of (to) the king from his own resources, when the sacrifices had been neglected because of the war, so that the

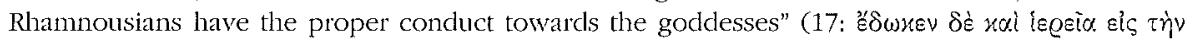

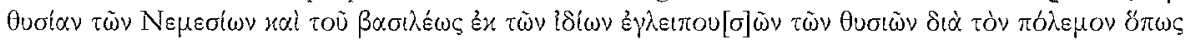

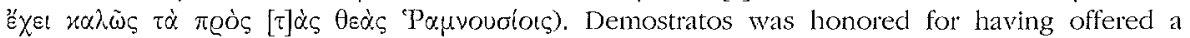
thanks-giving sacrifice to Zeus Soter and Athena Soteira upon the liberation of Athens from the

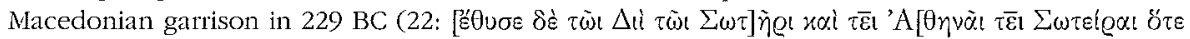

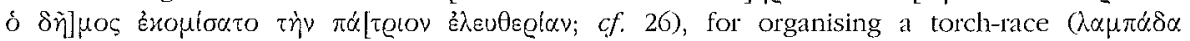

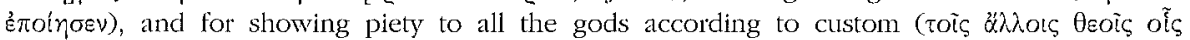
$\pi \alpha \tau$ Q iov $\tilde{\eta} y$; the same formulation in $\mathrm{n}^{\circ} 23$ ). Sacrifices to Zeus Soter and Athena Soteira were offered for the well-being of the soldiers, the people, and the young men (31, 225 BC: $\pi$ sel

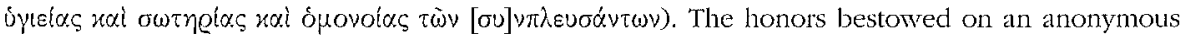

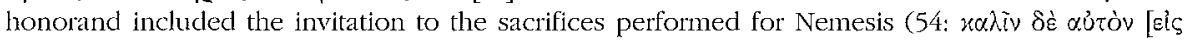

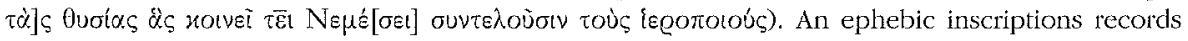

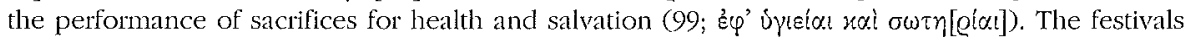
attested in Rhamnous include the Dionysia (15) and the agons of the Ptolemaia and Diogeneia (see above).

Hymns: A metrical text which alludes to the punishment of the hybris of the Persians by the goddess, was inscribed in the 1st or 2 nd cent. $\mathrm{AD}(165=S E G$ XIX 222). On the basis of a new fragment of the right-hand column P. suggests that the text is a hymn (cf. 1. 15: buvoc) composed and inscribed at the inititive of Herodes Atticus (cf. 1. 17: 'A $\lambda x \alpha i \delta \alpha \varsigma$ ); the text possibly refers to the sacrifice of as many goats as Persians killed in Marathon on behalf of Artemis Agrotera (1. 12: $\alpha l y \tilde{\omega} v ;$; $f$ XEN., Anab. III, 2, 11-12). [The second fragment undoubtedly belongs to the same stele, but is it really part of the same literary text? We may have a hymn to Nemesis on the left column, and a hymn to Artemis Agrotera on the right onel.

Associations: An association of worshippers of Sarapis ( $\tau \dot{\partial}$ kotvòv $\tau \tilde{\omega} v \sum \alpha \varrho \alpha \pi t \alpha \sigma \tau \omega \tilde{\omega} v$ ) honored the general Apollodoros; when they requested to purchase an estate that he owned, in order to build a sanctuary of Isis and Sarapis, Apollodoros showed his piety and donated the land $(* 59,3 \mathrm{rd}$ cent. BC). A decree of an association of worshippers of Amphiaraos, which had been founded by

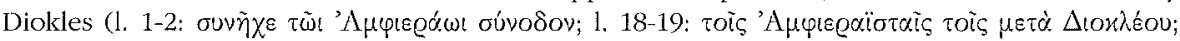

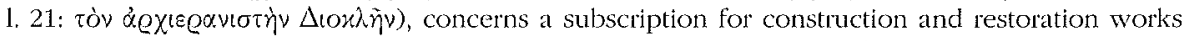
in the sanctuary of Amphiaraos, probably after a period of wars (167, late 3rd cent. BC); the

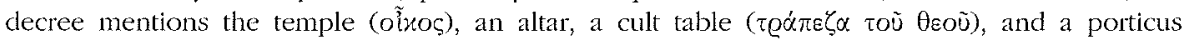

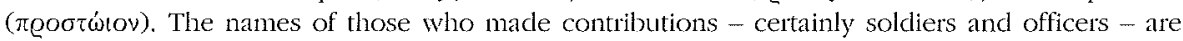
listed at the end of the decree; the contribution of Onesimides consisted in the donation of $\tau \dot{\alpha} \varsigma$

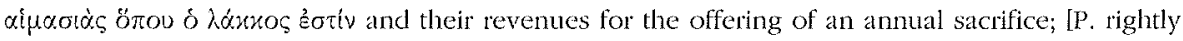

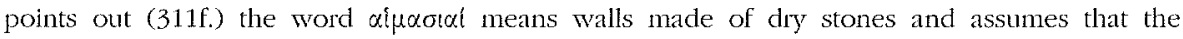
revenues originated in the use of a cistern $\left(\lambda \alpha \% x_{0}\right)$; this is possible, although the formulation

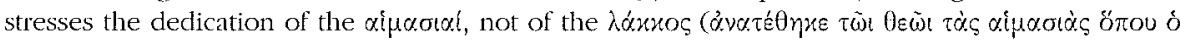

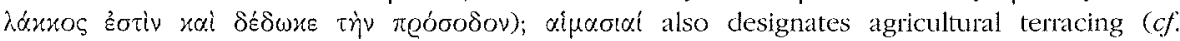
L. Foxhall, "Feeling the Earth Move: Cultivation Techniques on Steep Slopes in Classical Antiquity", in G. ShipleY - J. SAlMon, eds., Humam Landscapes in Classical Antiquity, London, 1996, p. 4467); Onesimides, one of only three Rhamnousians among the donors, may have given 
the revenues from land won through agricultural terracing "near the cistern", not the revenues "from the cistern"]. A decree of the council $(179,83 \mathrm{BC})$ concerns the dispute between the priest

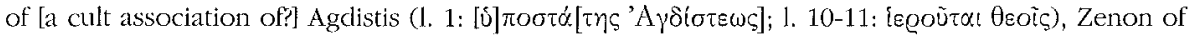

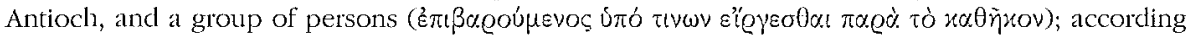
to the decree of the council Zenon should exercise his duties undisturbed; the cult personnel is

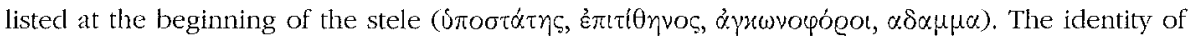

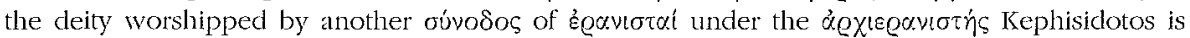
not known $(203,41 \mathrm{BC})$.

Ruler cult: A decree concerns the establishment of the ruler cult (ioóleot tupai) for Antigonos Gonatas (7). Dedications were made to Thea Livia (156) [see supra $n^{\circ}$ 92] and Claudius (157). A text mentions the priest of Thea Rome and Sebastos Kaisar (156). Cult officials: There are references to hietopoioi $(15,54, * 59,78)$, priests $(120,155)$, and priestess $(121-122,133)$; [we point out that the personal name Hieropoios $(15,133,233)$, is almost exclusively attested in Rhamnous (see LGPN II, s.v., three out of four attestations); it must be related to the local office of the hieropoioi]. [AC]

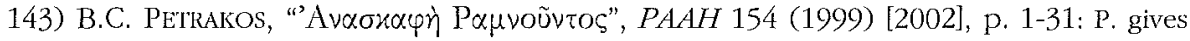
a report on new epigraphic finds in the fortress of Rhamnous. A decree of the unit of the kryptoi in honour of their general mentions the performance of the sacrifice of the exiteteria for Aphrodite and the other gods (p. 7-9 $\mathrm{n}^{\circ}$ 6, late 3rd cent. BC) [for the exiteteria see $E B G R$ 1996,

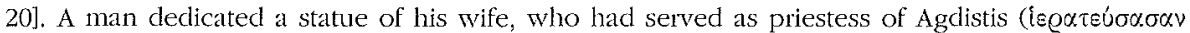
'A $\psi v \eta \dot{\sigma} \sigma t \delta t)$, praising her for her piety (17-19 $\mathrm{n}^{\circ} 20$, 2nd cent. AD). A bronze crescent moon

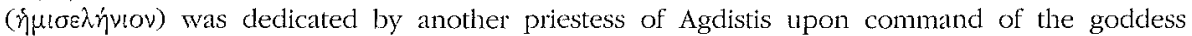

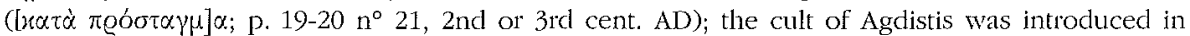

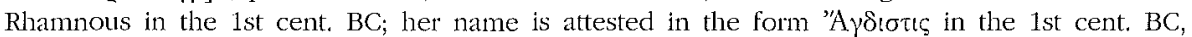

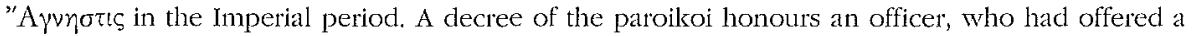
sacrifice to Themis and Nemesis at his own expenses inviting the paroikoi to attend the sacrifice (p. 22-23 $\mathrm{n}^{\circ} 26,3 \mathrm{rd}$ cent. BC); another fragmentary decree for a general mentions a sacrifice

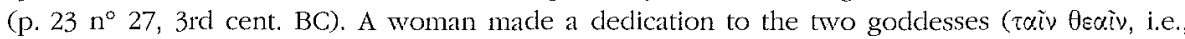

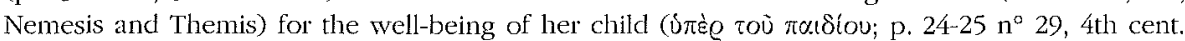

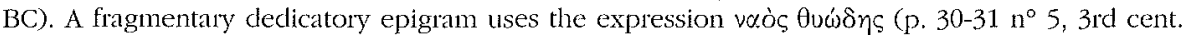

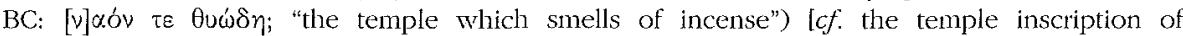

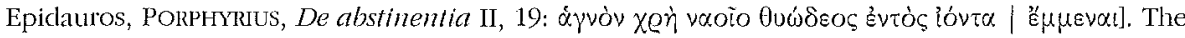
other texts include a dedication to Aphrodite Hegemone by a general (p. $7 \mathrm{n}^{\circ} 5,221 \mathrm{BC}$ ), a dedication to Isis (p. 21-22 $\mathrm{n}^{\circ} 24,2$ nd cent. $\mathrm{AD}$ ) and a fragmentary text which mentions the goddess (Nemesis?; p. $22 \mathrm{n}^{\circ}$ 25, undated). [AC]

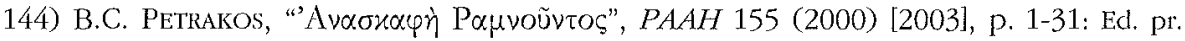
of several inscriptions found in the fortress of Rhamnous in Attika. They include two dedications, which do not name the recipient (p. 8-9, $\mathrm{n}^{\text {"is }} 7-8$, 3rd-2nd cent.). A dedication of torches, probably by the winners at the Diogeneia and Ptolemaia, is addressed to Zeus Soter and Athena Soteira $\left(\mathrm{n}^{\circ} 14,106 \mathrm{BC}\right.$ ); another similar dedication was found in the telesterion (p. $17 \mathrm{n}^{\circ} 1,2 \mathrm{nd} / 1 \mathrm{st}$ cent.). A dedication by the general Epichares to Heros Archegetes (p. 19-20 n 1 , c. 268 BC) was found near the south porter's lodge. Other stray finds include a column inscribed with a dedication to Themis and Nemesis; the very fragmentary text possibly also mentions the initiation of the dedicant in the mysteries in Eleusis and visits to other sanctuaries (p. 22-23 $n^{\circ} 1$; Imperial period). A cult table was dedicated to Dionysos (p. 23-24 $n^{\circ}$ 2; 3rd cent. BC). Pait of the name of the Heros Archegetes is preserved on a seat from the theater (possibly a dedication by his priest to Dionysos; p. $2411^{\circ} 4$; undated). [AC]

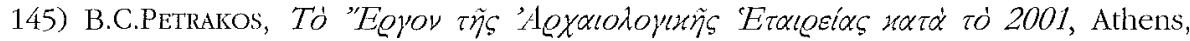
2002: P. mentions the discovery of an inscribed capital with the inscription ['] early Christian basilica in Messene (Imperial period, p. 50). The church must have been erected on the spot of the sanctuary of Sarapis and Isis (cf. PAus., IV, 32, 6). [AC] 
146) G. PeTzL, "Varia epigraphica", EA 33 (2001), p. 51-56 [BE 2002, 415]: P. points out that the god Ouarathes mentioned in a new inscription from east Lykia [supra $n^{\circ}$ 82] was already attested. A bronze tablet of unknown provenance (Charles Ede Ltd., Wriling and Lettering in Antiquity XIII, London, 1996, $\mathrm{n}^{\circ} 28 ; 2 \mathrm{nd} / 3 \mathrm{rd}$ cent.) is inscribed with a dedication to Mes Ouarathes as fulfillment of a vow; the dedication was brought to the sanctuary not by the dedicant himself, but by another person ( $\delta l^{\prime}$ 'Eepaiou Kin $\delta$ oviou). The provenance of the tablet must be the sanctuary of Mes Ouarathes in Mnara in Lykia; the service of priestesses in the cult of

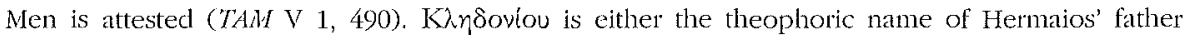
(from the oracular deities Kkledones) or the designation of a cult office ( $x \lambda$ n $\delta \delta$ voos, i.e., a prophet;

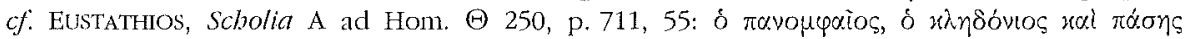

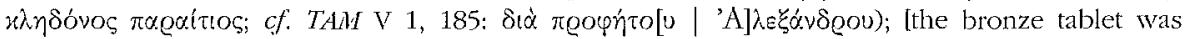
attached to the ex-voto; for this practice $c f$. G. SALAPATA, "Greek Votive Plaques: Manufacture, Display, Disposal", BABesch 77 (2002) p. 19-42, and supra ${ }^{\circ}$ 76]. [JM]

147) L. Pıolot, "Le recrutement des musiciens pour les fêtes à l'époque hellénistique: le cas messénien", in Chanter les dieux, p. 279-306: On the basis of the lex sacra concerning the mysteries of Andania (LSCG 65 lines $73-75$ and 95-99, 92/91 BC) P. attempts to reconstruct the procedure followed for the recruitement and selection of musicians in Hellenistic festivals. In Andania the musicians were not sent by an association of Dionysiac technitai, but were selected by the cult personnel (hieroi) from among the available musicians $c f$. IG XII 9, 297; $I G I X 1^{2} 4$, 798). These musicians should be distinguished both from those who participated in musical competitions and from the "public" auletai (1. 115). The verb $\lambda \varepsilon \iota \tau o v e y^{\prime} \omega$, which is used in this context, refers to a "cult service" (cf. I.Rhamnous 179; IG VII 3083 lines 23-26). [AC]

148) P. PoccetTI, "Due tabellae defixionis osco-greche dalla Calabria nel Museo Archeologico di Napoli", in Miscellanea Gasperini II, p. 745-771: P. republishes two defixiones found in graves in Calabria (Laos, $4 \mathrm{ch} / 3 \mathrm{rd}$ cent. BC). The texts, written on lead tablets, consist of the Oscian names of persons ( 8 persons in tablet A, 5 persons in tablet B). P. comments on the similarity between these Oscian texts and Greek defixiones in Magna Grecia. [AC]

149) A.M. Prestianni Giallombardo, "L'oracolo di Dodona e le navigazioni adriatiche nei secoli VI-IV a.C.", Hesperia 15, p. 123-136: Based on the observation that terms related

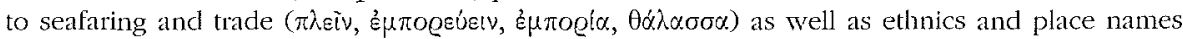
from both sides of the Adria (Epidamnos, Apollonia, Alyzeia, Metapontion, Sicily, Hergetion) appear in several of the oracular enquiries found in Dodona (6th-4th cent.), the author suggests that Zeus Naios was regarded as a patron of seafaring. The epithet Naios possibly does not derive from vaóc/val $(\omega$ - in this early period there was no temple of Zeus in Dodona -, but either from vów (flow) or vaù (ship). Literary sources associate Zeus Naios with seafaring (Anecdota Graeca p. 283, 22-25 ed. Bekker) and water (Schol. ad Il. 16, 233). [AC]

150) F. QueYrel, "Inscriptions et scènes figurées peintes sur le mur de fond du xyste de Delphes", BCH 125 (2001), p. 333-387: Ed. pr. of a very interesting group of painted inscriptions found in the gymnasium of Delphi (2nd-3rd cent.). The texts commemorate the victories of boy runners at the Pythia. Some of the texts begin with acclamations and

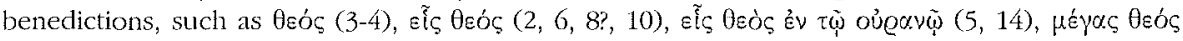

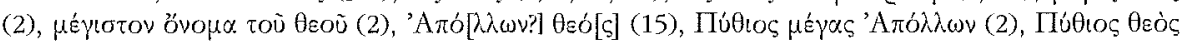

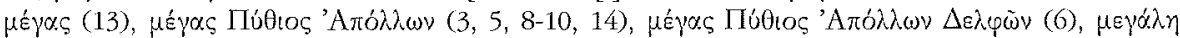

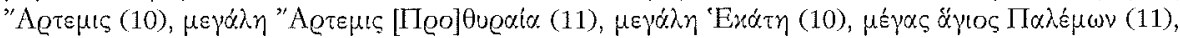

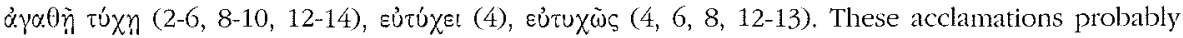
correspond to the acclamations of the audience in the stadion during the athletic competitions. The epithet Prothyraia was already attested for Artemis in Epidauros (IG IV2 276) and Pergamon (I.Pergamon VIII.3, 161). One of the athletes (3) had the signum Daidalos (i.e., fast as if equipped with the wings of Daidalos). Some of the dipinti are accompanied by images, such as pomegranates - a symbol of the Pythian agon - and a representation of Artemis and Palaimon an allusion to the Isthmia (11). [AC] 
151) J.-P. ReY-CoquaIs, "Inscriptions inédites de Sidon", in Miscellanea Gasperini II, p. 799-832: Ed. pr. 62 epitaphs from Sidon. In one of the texts the deceased woman is given consolation: "have courage; after your death your husband will follow you to the Hades" (قágol.

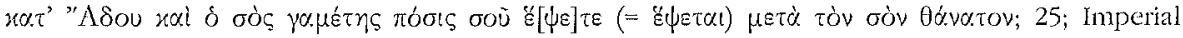
period). $[\mathrm{AC}]$

152) J. RfYnolds, "New Letters from Hadrian to Aphrodisias: Trials, Taxes, Gladiators, and an Aqueduct", JRA 13 (2000), p. 5-20 [SEG L 1096]: Ed. pr. of an important inscription containing four letters sent by Hadrian to Aphrodisias (AD 119, 124 and 125). The third letter (lines 27-41, $\mathrm{AD} 125$ ) is of particular interest for the office of the high priest of the civic emperor cult. We give R.'s translation: "The funds which you have reserved for the aqueduct I confirm. And since there are certain of your citizens who say that they have been nominated for the high priesthood when they are incapable of undertaking it, I have referred them to you to examine whether they are able to undertake the liturgy and are evading it, or are telling the truth; if, however, some of them were to appear to be better off, it is fair that they should hold the high priesthood first. I concede that you should take money from the high priests instead of gladiatorial shows; not only do I concede but I praise your proposal". As R. assumes, imperial approval was sought for - despite the status of Aphrodisias as a free city - because the decisions to divert money for the aqueduct and to ask the high priests for money, instead of gladiatorial shows, may have met with some resistance. One also notes the unwillingness of a number of citizens to undertake the liturgy of the high priesthood. The new text shows that the high priests were nominated ( $\pi \varrho \circ \beta \dot{\alpha} \lambda \lambda \varepsilon \sigma \theta \alpha$ ), possibly by their predecessor. This letter is the first evidence for Hadrian's disapproval of gladiatorial combats, which by his time had become part of the festival of the imperial cult [Cf. D. CAMPANLE, "Noterelle ai nuovi documenti da Afrodisia", ZPE 135 (2001), p. 138. For the request of Aphrodisias that high priests should give money (for the aqueduct?) instead of funding gladiatorial shows cf. an inscription at Tempsianoi (H. MALAY, Researcbes in Lydia, Mysia and Aiolis, Vienna, 1999 (TAM, Ergänzungsband 23), p. 115 n $^{\circ} 127$, c. 180-192): Following the request of the city, a priest provided the money he was supposed to spend for banquets for the construction of the aqueduct; $c f$. A. CHANIOTIS, "Negotiating Religion in the Cities of the Eastern Roman Empire", Kemos 16 (2003), p. 180]. [AC]

153) M. RicL, "Donations of Slaves and Freeborn Children to Deities in Roman Macedonia and Phrygia: A Reconsideration", Tyche 16 (2001), p. 127-160: The starting point of this fundamental study of the donation of slaves and freeborn children to sanctuaries is the publication of the corpus from Leukopetra ( $c f$. EBGR 2000, 155). R. summarizes the content of the texts and rightly points out that these documents should not be regarded as manumissions [cf. SEG L 597]. The act of conveyance is never described as a manumission, but as a gift or an offering; the clause which prescribes the deposition of all documents concerning the donated slave in the sanctuary strengthens this interpretation; in addition to this, one of the texts explicitly states that a slave was donated because her master was unable to repay a debt to the sanctuary (I.Leukopetra 134). The provision that a slave was not to be alienated from the goddess, aimed more at protecting the rights of the goddess, who was to be served by the donated persons on the customary festive clays, than those of the clonated slave. Explicit clauses about the future offspring of the donated slave show that the legal status of the donated slaves was not automatically inherited by their offspring. A group of texts mentions the double obligation of the slaves of remaining with their former master for the latter's lifetime (paramone) and of serving the goddess on the customary days; but service in the sanctuary is also implied in the texts which only

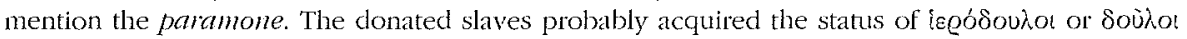

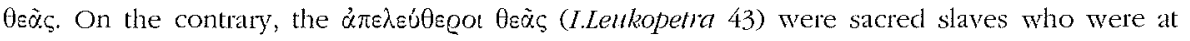
some point released by the goddess from the obligations imposed on them at the moment of the consecration (cf. SEG XXVII 932). The motives of the donors, whenever stated, were religious in nature: divine command or punishment, fulfillment of a vow, gratitude for help received. In addition to the sanctuary of Meter Theon at Leukopetra, donations of slaves were practiced in other Macedonian sanctuaries as well. Only in five acts of donation, in which the words

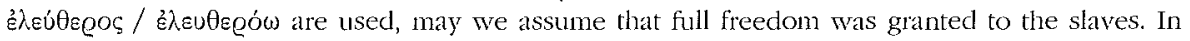
the second part of her article R. suggests some improvements in the reading and interpretation of 
several texts from Leukopetra (I.Leukopretra 5, 12, 26, 45-46, 51, 53, 58, 63, 78, 90, 93, 115, 136 150 ) and from the sanctuary of Apollon Lairbenos (cf. EBGR 2000, 169). We single out a few of her remarks: In I.Leukopetra 53 a lost slave-girl was dedicated to the goddess; if she turned up she was to become property of the goddess; this procedure is also attested in a pittakion from Maionia (?, SEG XXVIII 1568) [in the same venue EBGR 2000, 155]. In I.Leukopetra 150 R. suggests

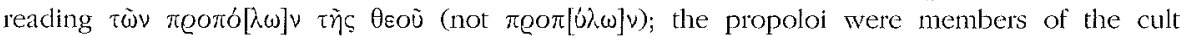
personnel. [On the new corpus of Leukopetra see also the review by E.A. MEYER, $A / P b 123$ (2002), p. 136 140]. With regard to the texts from the sanctuary of Apollon Lairbenos, R. points out that the main purpose of the donations was not to convey freedom to the slave, but to attach him to the god. The number of consecrated children was much higher in Phrygia than in Macedonia. In the Phrygian texts the term $\theta \varrho € \pi \tau o ́ s$ probably designated slaves. As in Macedonia, the motives for the donation were religious in nature. In the text $K 43 \mathrm{R}$. regards the two donors, Apollonios and his daughter Ammis, as two ouveeol, i.e., freeborn individuals who had been dedicated to Apollon "by their parents"; [correct: Apollonios must have been dedicated by his parents; being an legós he dedicated his own daughter to Apollon, and finally, together with his daughter, a slave which he had brought up; this text shows the long-term commitment of families to the sanctuary]. Apollonios and Ammis also dedicated a workshop (according to R.'s reading an

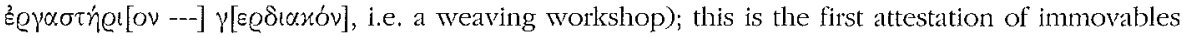
being dedicated to Apollon Lairbenos. [AC]

154) M. Ricl, "Phrygian Votive Steles", EA 33 (2001), p. 195-198 [BE 2002, 419]: R. makes some remarks on the recent edition of 17 Phrygian inscriptions (EBGR 1999, 61). We single out

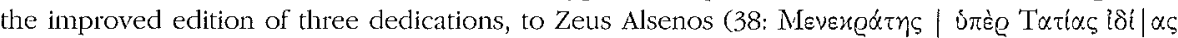

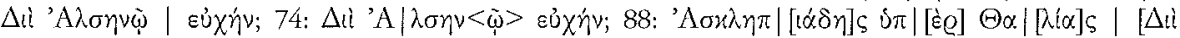
'A $\lambda \sigma \mid[\eta \dot{\omega}|\varepsilon \dot{\omega}| \chi \dot{\eta} \nu] .[\mathrm{JM}]$

155) K.J. RIGSBY, "Founding a Sarapeum", GRBS 42 (2001), p. 117-124: A letter in the Zenon archive, sent by Zenon to the dioiketes Apollonios (SB III 6713, 257 BC), concerns the foundation of a Sarapeum. Earlier scholarship thought of a foundation abroad (in Karia, Palestine, or Aspendos). But as R. observes, the verb $\delta(\alpha \pi \lambda \dot{\varepsilon} \omega$ in this document means the crossing of the Nile. Consequently, this document offers no evidence for Ptolemaic religious policy overseas. The foundation was probably intended to take place in Memphis. Zoilos, following the god's command, was not planning a replacement for the great Sarapeum west of Memphis, but the foundation of a precinct in the Greek quarter of the city which would serve the needs of Greek worshippers; this text does not document an effort to bring Greeks and Egyptians together. [AC]

156) K.J. Rigsby, “A Roman Epigram for Asclepius”, $Z P E$ 134 (2001), p. 107-108; R. presents a new interpretation of the iambic epigram inscribed on an altar dedicated to Asklepios

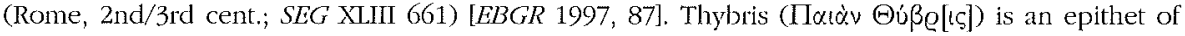
Asklepios. R. identifies Lupus, the person who was healed from tuberculosis by Asklepios, as a Platonic philosopher, a companion of the dedicant Arria. Arria "the Platonist" is mentioned by Galen as an admirer of Plato; she was also the dedicant of a thanks-giving dedication for her'

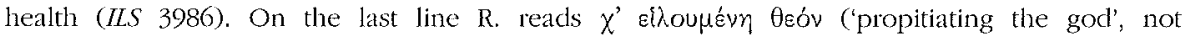
$\chi \varepsilon(\lambda \circ \cup \mu \varepsilon \dot{\varepsilon} \vee \eta) .[\mathrm{JM}]$

157) K.J. Rigsizy - K. Hallof, "Aus der Arbeit der "Inscriptiones Graecae" X. Decrees of Inviolability for Kos", Chiron 31 (2001), p. 333-345 [BE 2002, 323]: R.-H. publish five fragmentary decrees with which Greek cities recognized the asylia of the Asklepieion of Kos ( 242 BC). An Ionian city (Teos, Abdera, Priene, Miletos?') recognized the inviolability of the Asklepieion and decreed to send theoroi, when the Koans proclaim the Asklepieia; A chief-theoros and two theorol were to be elected; they were to travel to Kos in order to perform the customary sacrifices to Asklepios (1). The Cretan cities of Istron, Phaistos, and Hierapytna decreed to accept the inviolability of the sanctuary, the sacrifice, the truce, and the festival of Asklepios on Kos; the decrees were to be inscribed by the Phaistians in the sanctuary of Apollon Pythios lin Phaistos or in Gortyn?], the Hierapytnians in their own sanctuary of Asklepios, and the Istronians in their prytaneion (2). Another three decrees (3-4) were issued by unidentified cities, which had been 
visited by the same Koan architheoros (Hippotes) accompanied by two theoroi (Aischros and Epikles). A fragmentary inscription preserves the end of a decree perhaps of Kerkyra and the beginning of a decree of Leukas. [JM]

158) P. RoBiano, "L'épigramme sur Apollonios de Tyane et Alexandre, le faux prophète", EA 33 (2001), p. 81-83: Observing a series of similarities in phraseology and ideology between LuCIAN's presentation of Alexander of Abonouteichos and the epigram for Alexander's teacher, Apollonios of Tyana (SEG XXVIII 1251, Aigeai?), R. suggests restoring the last distich of

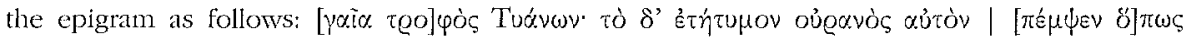

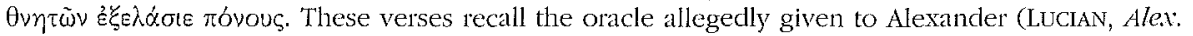

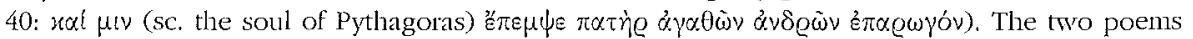
reflect the same idea: Apollonios of Tyana and his disciple Alexandros vere sent by the supreme god as saviours of mankind. The reference to the Sky, who sent Apollonios, corresponds to the restored reference to the earth of Tyana, which nourished the holy man. Other correspondences between the epigram for Apollonios and Lucian's text may be seen in the conception of Glykon,

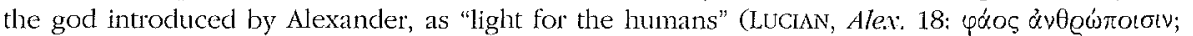

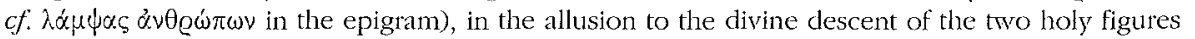

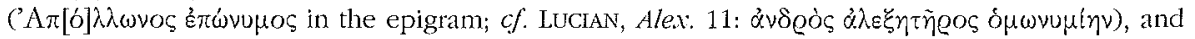

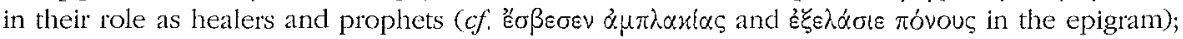
[on Alexander of Abonouteichos see now also G. SFAMENI GASPARRO, "Alessandro di Abonutico, lo 'pseudo-profeta' ovvero come construirsi un'identità religiosa. I. Il profeta, 'eroe' e 'uomo divino", SMSR 62 (1996) [1998], p. 565-590; ead., "Alessandro di Abonutico, lo 'pseudo-profeta' ovvero come construirsi un'identità religiosa. II. L'oracolo e i misteri', in C. BONNET - A. MOTTE (eds.), Les syncrétismes religieux dans le monde méditerranéen antique. Actes du colloque international en l'bonmeur de Franz Cumont, Bruxelles / Rome, 1999, p. 275-305; A. CHANIOTIS, "Old Wine in a New Skin: Tradition and Innovation in the Cult Foundation of Alexander of Abonouteichos', in E. DaBrowa (ed.), Tradition and Innovation in the Ancient World, Krakow, 2002 (Electrum, 6), p. 67-85]. [AC]

159) J. RumSCHEID, Kranz und Krone. Zu Insignien, Siegespreisen und Ebrenzeichen der römischen Kaiserzeit, Tübingen, 2000: In this excellent study R. collects the epigraphic, archaeological and numisnatic evidence concerning the various types of wreaths and crowns worn by magistrates, priests, agonothetai, and the winners of agons. With regard to the crowns decorated with busts or inages of emperors and gods R. rejects the interpretation of these crowns as crowns of high priests of the emperor cult and argues that they were worn by agonothetai. She bases this view primarily on the inscription concerning the agon Demostheneia in Oinoanda (EBGR 1988, 193; SEG XXXVIII 1462). [There can be no doubt that such crowns were worn by agonothetai (e.g., $\mathrm{n}^{\text {"N }} 12$ and 24 in R.'s catalogue), but in my view nothing supports the claim that they were worn exclusively by agonothetai. We have representations of persons with such crowns, who are either explicitly identified as high priests (Appuleius and Eurykles in Aizanoi: 1) or are known to have served as such (Plancia Magna: 32; Dometinus Diogenes: 10). The organisation of agons was one of the most prominent activities of high priests, but this does not mean that they wore the 'Büstenkronen' only on this occasion and in their capacity as agonothetai. In this context it should be pointed out that crowns decorated with images of gods, such as the crown supporting a statuette of the enthroned Sarapis found in Douch (EBGR 1990, 255), may be more common than R. assumes (with reference to the crowns of the high priests of the ruler cult

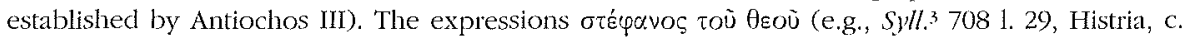

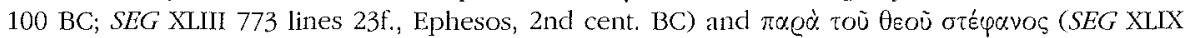
1752 1. 16, Ilion, c. 270 BC) possibly refer to crowns decorated with images of gods. For the importance of the crown as the primary attribute of the high priest see the honorary epigram for

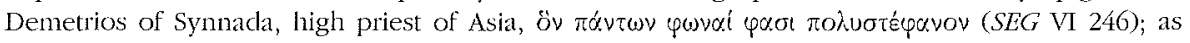

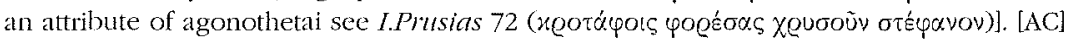

160) J. RUMSCIEID - F. RUNSChEID, "Gladiatoren in Mylasa", AA (2001) [2002], p. 115136: R.-R. collect the evidence for gladiatorial combats in Mylasa, which consists of representations of gladiators in reliefs, epitaphs (L.Mylasa 532, 537-539), honorary inscriptions (I.Mylasa 531, 
534), a dedication (I.Mylasa 533), and a graffito. An honorary decree for a high priest of the emperor cult, who had organised gladiatorial shows (I.Mylasa 531), possibly concerns the provincial, and not the civic emperor cult, but there is evidence for venationes in connection with the emperor cult (I.Mylasa 534). The gladiatorial shows in Mylasa, as part of the emperor cult, seem to have been more popular than in neighbouring cities; they may have taken place in the theater. $[A C]$

161) I. RuTHFrFord, "Paeans at Ptolemais?", $Z P E 135$ (2001), p. 41-42: In the Roman period paianistai sang paeans in honor of Asklepios, Sarapis, and the emperors. The repertoire of paianistai seems to have included examples from the Classical period. R. suggests that the text of Pindar's paeans in P.Oxy. 841 (found in Oxyrhynchos, but probably originally from Ptolemais) may have been commissioned by paianistai in Ptolemais Hermiou. The existence of paianistai in Ptolemais may be inferred from the 'Erythraean paean' to Asklepios (cf. LSAM $24=$ I.Erythrai 205; $I G \mathrm{II}^{2} 4509$ ) which was inscribed and set up by the city during the reign of Trajan (IGR I 1154). Unlike other copies of this paean, the copy in Ptolemais includes a fourth strophe, which calls Apollon Pythios to ensure the regular inudation of the Nile. The paianistai in Ptolemais seem to have been linked with the cult of Asklepios (not Sarapis), but also with the imperial cult. [R. regards as uncertain "whether or not the cult of Asclepius pre-existed at Ptolemais"; but IGR I

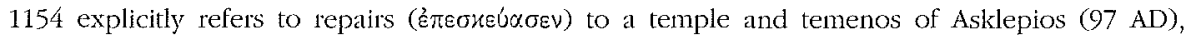
whose cult obviously predates the reign of Trajan]. [AC]

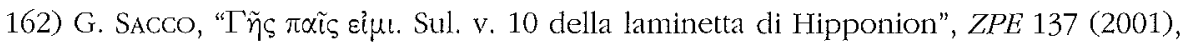
p. 27-33: In the Dionysiac-Orphic texts the deceased person is advised to identify himself to the

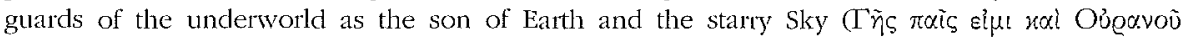

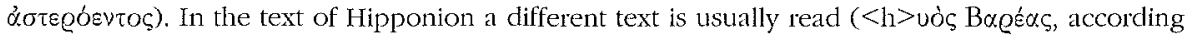

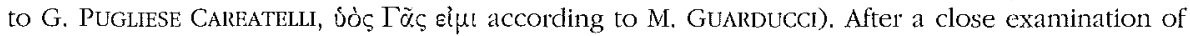

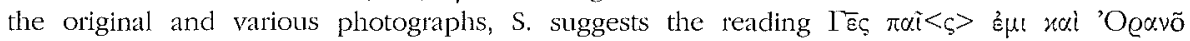
$\dot{\alpha} \sigma \tau \varepsilon \varrho o ́ \varepsilon v \tau o c$. The new reading shows that the leaf of Hipponion uses the standard formulation in the Ionic dialect. S. presents a new edition of the entire text, with minor differences from earlier editions. The most significant readings are the confirmation of OPOEENTO $\Sigma$ in line 9 (perhaps

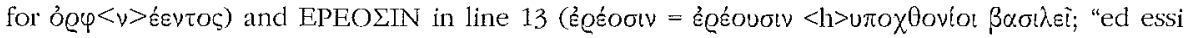
lo referiranno al re degli inferi"). [AC]

163) P. SANCHEZ, L'Amphictionie des Pyles et de Delpbes. Recherches sur son rôle bistorique, des origines au II' siècle de notre ère, Stuttgart, 2000 [BE 2002, 209; SEG L 495]: In his comprehensive study of the history and the organisation of the Delphic Amphictyony $S$. discusses the accounts of the 4th cent. $\mathrm{BC}$ (p. 124-152), the composition of the amphictyonic council in the 3rd cent. BC (p. 287-302), the Delphic festivals of the Pythia and the Soteria (p. 303-309), the promotion of asylia (p. 335-359), the amphictyony in the 2nd-1st cent. BC (p. 364-425), the evolution of the amphictyonic council and the officials of the amphictyony during the Roman Imperial Period (p. 426-463), the structure of the amphictyony (p. 466-494), and the offices of hieromnamon, pylagoras, and agoratros. [AC]

164) M. SARTRE, "Gouverneurs d'Arabie anciens et nouveaux", in Miscellanea Gasperini II, p. 971-990: Ed. pr. of a building inscription which refers to repairs in a temple funded by a beneficiarius (8; Phaina, c. AD 238). [In another text (10, Bostra?, 3rd cent. AD) S. restores:

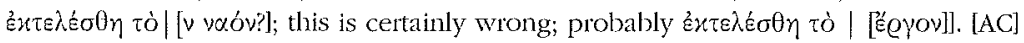

165) M. Sartre, "Les manifestations du culte imperial dans les provines syriennes et en Arabie", in C. Evers - A. TSINGARIDA (eds.), Rome et ses provinces. Genèse et diffision d'une image du pouvoir: Hommages à Jean-Charles Balty, Bruxelles, 2001, p. 167-186: S. collects the rather limited evidence for the emperor cult in Syria, Judaea, and Arabia. Only two high priests are known in Syria: Dexandros, the first high priest under Augustus, and Diogenes in c. $\mathrm{AD} 120$, who is designated as priest of four $\varepsilon \pi \alpha e \chi i \alpha !$ in Antiocheia. The term $\varepsilon \pi \alpha \varrho \chi^{i} \alpha$ probably did not designate provinces, but districts (Syria, Kilikia, Phoinike, Koile Syria). The evidence for the civic emperor cult in these provinces is far more abundant than for the provincial cult. [AC] 
166) M.H. SAYAR, "Weihung an Dionysos aus Rhosos", EA 33 (2001), p. 89-93 [BE 2002, 448]: Ed. pr. of a fragment of a small marble altar (Rhosos in Kilikia, 3rd-2nd cent. BC) dedicated

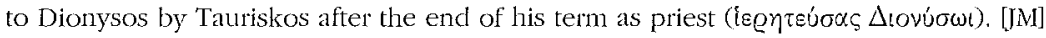

167) S. SCHORN, "Eine Prozession zu Ehren Arsinoes II. (P.Oxy. XXVII 2465, fr. 2: Satyros, Über die Demen von Alexandreia)", in K. Geus - K. Zimmrrmann (eds.), Punica - Libyca - Ptolemaica. Festschrift für Werner Huß, zum 65. Gebuntstag dargebracht von Schülem, Freunden und Kollegen, Leuven/Paris et al., 2001 (Studia Phoenicia, 16), p. 186-220: $S$. discusses the lex sacra which regulates the great procession in honor of Arsinoe II and the sacrifices during this event (P.Oxy. XXVII 2465). The first fragmentary lines give information concerning the route. The procession probably began at the temple of Arsinoe, the Arsinocion (1. 4). It was headed by the kanephoros (1. 8). The name of Arsinoe Philadelphos appears in 1.9 in the genitive possibly in a reference to the function of her cult statue during the procession. S. assumes that except for the prytaneis, the priests, the gymnasiarchoi, the ephebes and the rhabdophoroi, the population was not allowed to participate in the procession, suggest-

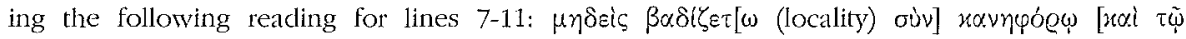

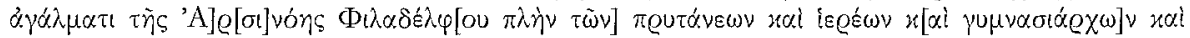

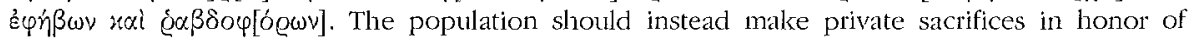
Arsinoe in front of the houses (1. 13) or on rooftops (1. 14). In lines 15-18 the sacrificial victims are defined: all animals except for sheep or goat were allowed. The altars were to be made of sand or at least be covered with sand (lines 18-21). Because of the prohibition of sheep sacrifices $S$. supposes that during this festival (Arsinoeia?) Arsinoe was honored as Isis. [JM]

168) S. ScULLION, "Three Notes on Inscriptions", ZPE 134 (2001), p. 116-120 [BE 2002, 182, 197]: S. observes that the different prices given for sacrificial sheep in the sacrificial calendar of the Marathonian Tetrapolis (IG II ${ }^{2} 1358=L S C G$ 20) [Cf: EBGR 2000, 109] do not depend on the gender of the recipient of the sacrifice, but on the gender of the animal - the price of a wether (male) being higher than that of an ewe (female) (p. 117f.). S. also suggests a new reading in one of the Epidaurian healing miracles (IG IV $122 \mathrm{l} .26 \mathrm{n}^{\circ} \mathrm{XXV}$ ). The text according to $\mathrm{S}$. reads

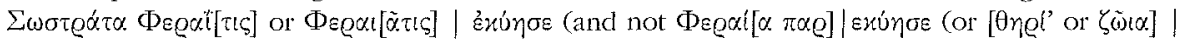
Exun $\sigma \varepsilon)$. Pheraitis is the ethnic of the Messenian city of Pherai. [This suggestion is not entirely

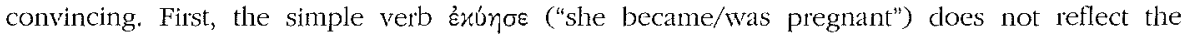
content of the healing miracle; at no point was Sostrata pregnant; since $\pi \alpha \varrho \alpha x u$ é

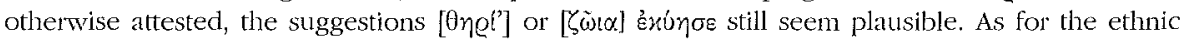
name, it is true that in most healing miracles we find ethnics from the Peloponnese, but a visitor from Thessaly, which claimed to have been Asklepios' bith-place, would be a nice advertisement for the Asklepieion of Epidauros. More important: leaving from Epidauros and going home Sostrata stopped at Kornoi; if Kornoi is to be identified with Korniatas, mentioned in the delimitation between Epidauros and Korinthos (A. MAGNETTO, Gli arbitrati interstalali greci, Pisa, 1997, $\mathrm{n}^{\circ} 36$ ), then Sostrata's journey followred a northeast direction and did not lead to Messenia]. [AC]

169) N. Sharankov, "A Dedicatory Inscription from Odessos", ZPE 137 (2001), p. 174178 [BE 2002, 84]: Ed. pr. of a dedicatory inscription inscribed on a bronze wheel, part of a candelabrum, found in 1964 in the Roman baths of Odessos ( $2 \mathrm{nd} / 3 \mathrm{rd}$ cent.). The candelabrum was dedicated by Orpheus to Herakles Kallineikos. The cult of Herakles Kallineikos was already attested in Odessos (IGBulg V 5038). Archaeological and other epigraphic evidence for Herakles' cult in the thermae (cf. IGBulg V $50745 \mathrm{c} 1,5 \mathrm{c} 2$ ) suggest that Orpheus may have been an

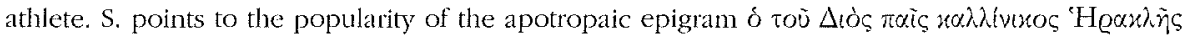

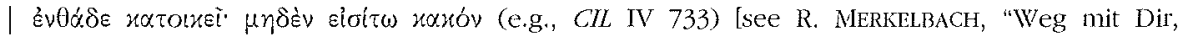
Herakles, in die Feuerhölle!", ZPE, 86 (1991), p. 1-43; MERKELBACH - STAUBER, Steinepigramme II 08/01/10; III 12/04/10]. [JM]

170) P. SIEwERT, "Il ruolo di Epidamno e dei Greci di oltremare a Olimpia in uno nuova iscrizione arcaica", Hesperia 15, p. 67-71: Ed. pr. of a fragmentary lex sacra which seems to regulate the presence of foreigners in the sanctuary of Zeus in Olympia (Olympia, c. 500 $\mathrm{BC})$. The text refers inter alia to damages caused by livestock to dedications (1. 7: $\dot{\alpha} \gamma \dot{\alpha} \hat{\lambda} \lambda \mu \alpha \tau \alpha)$ and 
to fines payable by the shepherd (voueuc). [The clause in 1.6 treats the same subject, i.e. the

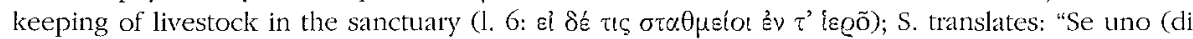
coloro) allestice un luogo di sosta nel santuario"; for $\sigma \tau \alpha \theta \mu \varepsilon i o$ cf. the term $\sigma \tau \alpha \theta \mu o c$, which is often used in connection with the periodical movement of flocks to pasture (see J.E. SKYDSGAARD, "Transhumance in Ancient Greece", in C.R. WhitTaker (ed.), Pastoral Economies in Classical

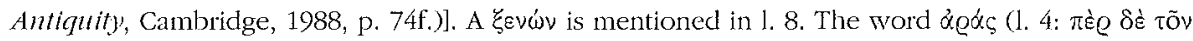

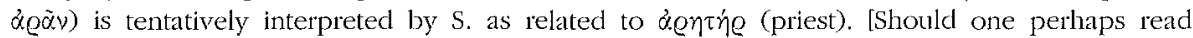

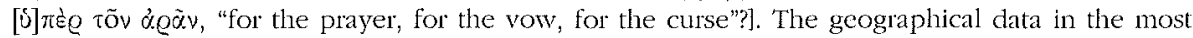

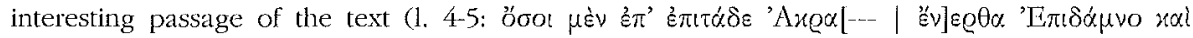

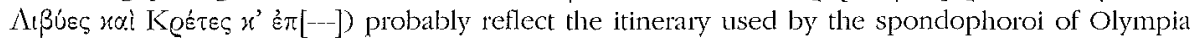
who announced the sacred truce. $[\mathrm{AC}]$

171) E. Sironen, "Lateinische Ehreninschriften für Constantin den Grossen und seine Nachfolger und andere Inschriften der Spätzeit aus Attika", ZPE 136 (2001), p. 257-266 [BE 2002, 586]: Ed. pr. of a fragmentary Christian curse (9) which uses the formula "he shall be followed by the curse of the 318 sacred fathers" (i.e. the participants in the consilium of Nikaia;

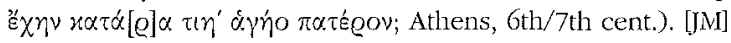

172) O.Y. SoKolova, "New Material from the Excavation of Nymphaeum", Talanta 3233 (2000-2001), p. 81-87: During excavations at the Bosporan city of Nymphaeum in 2000 a block of an inscribed architrave was found - most probably belonging to a propylon lof a sanctuary?]. According to the text Theopropides, son of Megakles, dedicated this entrance to

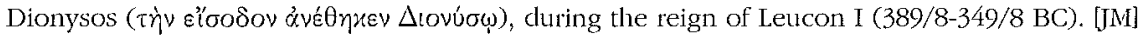

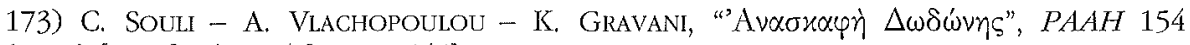
(1999) [2002] 147-154 [SEG L 545]: The excavators mention the discovery of an undetermined number of stamped roof tiles with the inscription $\triangle$ iò Ņ́ou ( $c f$. SEG XXXIII 477, XIV 666, XI,rX 644) in the prytaneion. [AC]

174) K. Sporn, "Auf den Spuren der kretischen Diktynna", in Ithake, p. 225-233: S. summarizes the cult of Diktynna in Crete as a patron of hunting, seafaring, and healing, her perception as a Nymph, and the history of the Diktynnaion. [AC]

175) M. STEIN, "Die Verehrung des Theos Hypsistos: Ein allumfassender paganjüdischer Synkretismus?", EA 33 (2001), p. 119-126 [BE 2002, 344]: According to S. the numerous dedicatory inscriptions addressed to Zeus Hypsistos, Theos Hypsistos oder Hypsistos are not expressions of a supposed pagan-Jewish syncretism, as suggested by S. MITCHELL [cf. EBGR 1998, 1901. One should continue to distinguish between pagan and Jewish dedications to divinities with the epitheton Hypsistos. The theosebeis were not a group of people practicing the supposed pagan-Jewish cult of Hypsistos Theos, but pagans with a strong affection towards Jewish religious practices. [JM]

176) K. Strobel - Chr. Gerber, "Feldforschungen in Tavium im Jahr 2000. Vorbericht", in $A S T 19.2$, p. 1-8: S.-G, report the rediscovery of a dedication to Theos Hypsistos (Tavium, 1st/2nd cent.; S. MitCHELL, Regional Epigraphic Catalogues of Asia Minor. II. The Ankara District. The Inscriptions of North Galatia, Oxford, 1982, $\mathrm{n}^{\circ} 418$ ). [AC]

177) A. Suceveanu, "Le 'Grand Dieu' d'Histria", Ktema 24 (1999) [2000], p. 271-281 [SEG

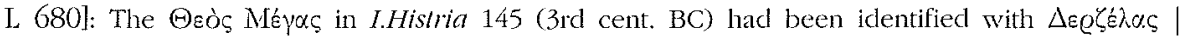
$\Delta \alpha \varrho \zeta \alpha \lambda \alpha \varsigma$, who was worshipped under this name in Odessos (IGBulg $\mathrm{I}^{2} 47$, 47bis, 48, 230bis). S. reject this identification and critically considers the possibility of an identification with Sarapis or (rather) Helios. [AC]

178) D. Summa, "Una iscrizione coregica di Thorikos?", $Z P E 136$ (2001), p. 71-76: S. suggests identifying a fragmentary list of names (Thorikos, 4th cent. BC; SEG XI 167) [EBGR 1990, 30] as a list of choregoi in the rural Dionysia (and not a list of winners at a contest of actors). [AC] 
179) J. TAITA, "Indovini stranieri al servizio dello stato spartano. Un' "epoikia" elea a Sparta in una nuova iscrizione da Olimpia", Dike 4 (2001), p. 39-85: A new inscription from Olympia (c. 470-440 BC) concerns the award of Eleian citizenship to Athanadas and Rhinon, "participation in the epoikia in Sparta and in Euboia", and the honor of receiving theoriai, i.e. serving as theorodokoi for the Eleian spondophoroi who announced the Olympic truce. T. suggests that Athanadas and Rhinon were citizens of Sparta and an Euboian city respectively. Their participation in the Eleian epoikiai probably concerned participation in the religious life of these Eleian communities. The Eleian epoikia in Sparta may be related to the presence of foreign specialists in the service of the Spartan community, such as the manteis Iamidai. In this context T. collects the evidence for private cults in Sparta. [AC]

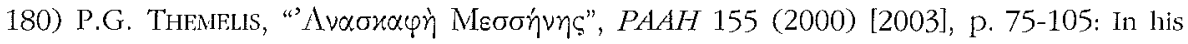
report on the excavations in Messene Th. gives the text of a fragmentary honorary decree for Claudius Saithidas Kailianos II (early 2nd cent. AD), high priest of the emperor cult for life and Heladarches (78-82), written on two bases found in the theater. [The text is very interesting with regard to rhetoric and formulations. The honorand and his parents (lines $7,11,18-19$ ) are praised for various benefactions with regard to sanctuaries (A 9: $\tau \tilde{\omega}$ v $\{\varrho \varrho \bar{\omega} v$ ) and the restoration of the proscenium of the theater. We remark a few interesting expressions. The behaviour of one of

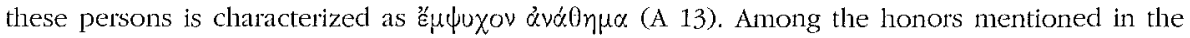

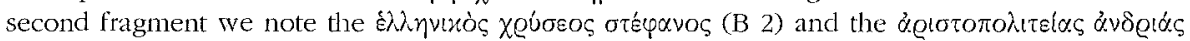

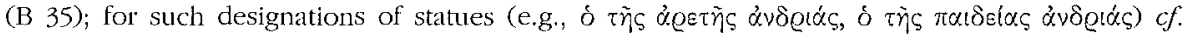
L. ROBER', "Inscriptions d'Aphrodisias", $A C 35$ (1966), p. 399. A statue of Saithidas' mother, who is

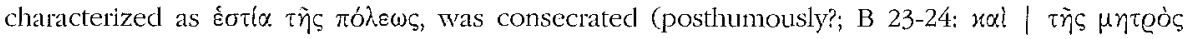

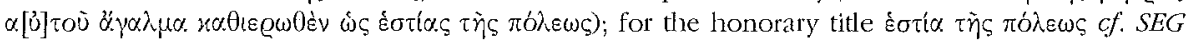
XXXIX 1792. The decree was to be published in all sites where Greek festivals took place (B 39:

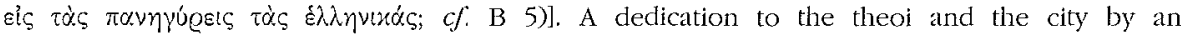
agoranomos was found in the agora (p. 85, 1st cent. AD). Two lists of ephebes, found in the stadium (p. 90-93, AD 70 and 91), are dated with reference to the priest (of Zeus Ithomatas). A dedication to Demeter was found near the gymnasium (p. 97, late 4th cent. BC). [AC]

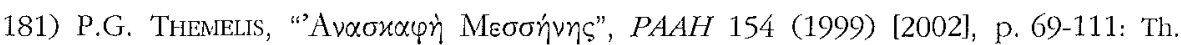
reports the discovery in the theater of Messene of the base which supported the statue of Pankrates, winner at the Pythia in diaulos in the category of boys (p. 79-80, late 2nd cent. BC). A fragmentary list of cult personnel found in the Asklepieion (p. 88-89, early 3rd cent. BC) mentions

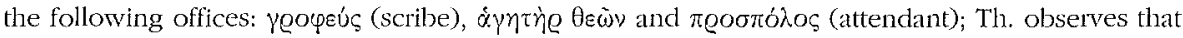
$\eta \dot{y} \dot{r}^{\prime} \tau \omega \mathrm{e}$ was the title of the priest of Aphrodite in Amathous and according to Hesychios the priest of the goddess at the Karneia; for this reason he assumes that the anonymous gods were the Karneioi theoi of Andania [the name of this office ("guide of the gods") may be associated with a procession, in which this official carried the images of the gods]. The other texts include a dedication made by a gymnasiarchos to Pantes Theoi and the city in the stadium (p. 91, 1st cent.

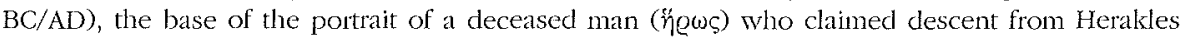

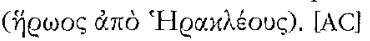

182) P. Themeis, "Monuments guerriers de Messène", in R. FrFi-STOLBA - K.GrX (eds.), Rechercbes récentes su. le monde bellénistique. Actes du colloque international organisé à l'occasion du 60' anniversaire de Pierre Ducrey (Lausanne, 20-21 novembre 1998), Bern, 2001, p. 199-215: Th. presents epigraphic evidence related to war monuments in Messene. A stele with the names of the men killed in a battle at Makistos (late 3rd cent. BC) was found in the gymmasium; the lack of a patronymic alludes to the heroisation of the war dead. In this context Th. presents two dedicatory inscriptions from the gymnasium: a dedication of a

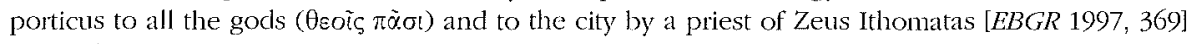
and a dedication to Hermes, Herakles and the city [cf. EBGR 1992, 222] (p. 199-201). An honorary epigram found near the gymnasium honors Damostratos of Sparta, who reconciled Spartans and Messenians (3rd cent.; p. 201-203). The Dioskouroi were worshipped in a sanctuary of Demeter and Kore, where soldiers dedicated a shield to Polycleukes (late 4th/early 3rd cent. BC; p. 203205). A funerary peribolos near the bouleuterion was the burial site of six men and four women 
(SEG XLVII 428; EBGR 1997, 368), who were probably killed in a street battle in Messene (214 or 201 BC; p. 206-207). [AC]

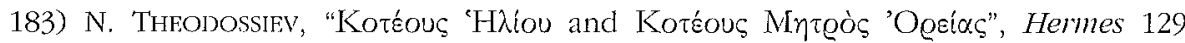

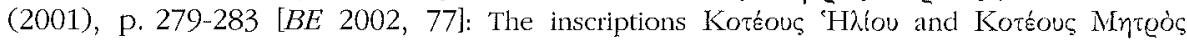
'Oeslas appear on two silver bowls (SEG XIIV 1554 13; EBGR 1996, 202, 2nd/1st cent. BC) [or' earlier; see M. SÈve, $B E 1996,971$. T. interprets the name as the nominative of the Thracian name

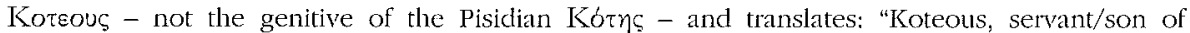
Helios", and "Koteous, servant/son of Meter Oreia". "During the Late Hellenistic period the Thracian dynast Koteous considered himself as a doctrinal son of the Great Goddess in her mountain image". T. associates this idea with the Dionysiac-Orphic texts, in which the mystes is regarded son of the Earth and the Sky, and with a painted vase from the Theban Kabeirion which represents the seated old Kabiros and his pais as a servant. [AC]

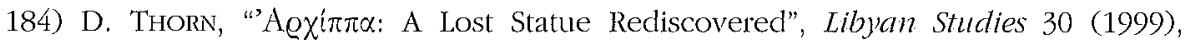
p. 69-76 [BE 2000, 742; SEG XLIX 2362]: The statue of a seated marble figure of a woman found near the sanctuary of Apollon in Kyrene can be identified with a statue originally found in

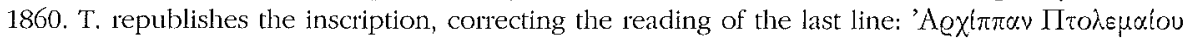

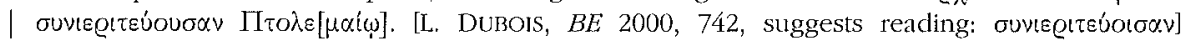
Archippa served as priestess of Artemis in the same year in which her father was priest of Apollon (1st cent. AD). [AC]

185) S.R. TOKHTAS'Ev, "New tabellae defixionum from Olbia", Hyperboreus 6 (2000), p. 296-316 (in Russian; German summary) [SEG L 702]: Ed. pr. of four lead tablets found during illegal excavations in the cemetery of Olbia (c. $350-300$ BC). The first text consists of three

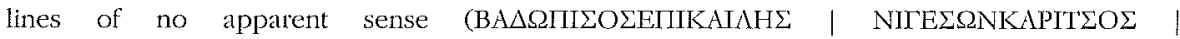
$\mathrm{BA} \triangle \mathrm{E} \Gamma \mathrm{EA} \mathrm{AI} \Omega \mathrm{N}$ ); [it is possible that the scribe intentionally confused the sequence of letters; for this practice see EBGR 1998, 270]. The other three defixiones consist of personal names in the nominative. [AC]

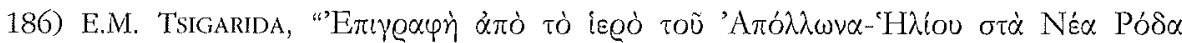
$\Xi \alpha \lambda x i \delta เ \tilde{n} \varsigma^{\prime}$ ", in Synedrio Epigrapbikes I, p. 151-156 [BE 2002, 285]: T. republishes with a more detailed commentary a fragmentary inscription from Nea Roda in Chalkidike (c. 450-400 BC) [cf. EBGR 1998, 272; SEG XIVI 947]. The text was found in a sanctuary of Helios or ApollonHelios, in the vicinity of Sane and Ouranopolis. The text refers to the sanctuary (1. 5: iegóv), and possibly served as a boundary marker. [AC]

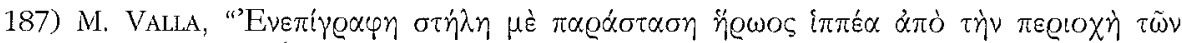

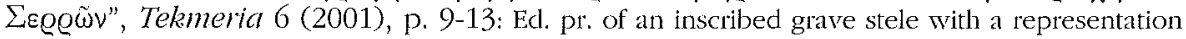
of a rider hero (Metochi Serron, Macedonia, 2nd cent. AD). [JM]

188) P. van Nuffelen, "Un culte royal de Séleucie du Tigre", EA 33 (2001), p. 85-87: According to $\mathrm{N}$. a fragmentary inscription found in Seleukeia on Tigris (Kelsey Museum, University of Michigan) attests to the existence of a remarkable form of ruler cult in the Hellenistic

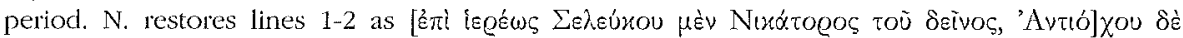

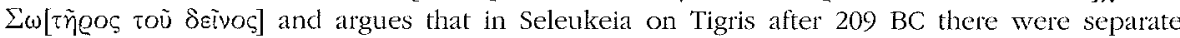
priests for each of the dead Seleucid kings in addition to the priest for the living sovereign. [JM]

189) I. VELÁZQUEZ, "Intersección de realidades culturales en la antigüiedad tardía: el ejemplo de defixiones y filacterias como instrumentos de la cultura popular", AnTard 9 (2001), p. 149-162: Through a study of late antique amulets and defixiones (especially 'prayers for justice' from the Iberian peninsula, Rome, and Gaul) V. shows how in this period traditional popular culture assimilated Christian elements (Biblical names, quotations from the Old and New Testament, hagiographical texts); she also stresses the uniformity of popular culture throughout the empire and the influence of magical handbooks. In this article V. presents the ed, pr; of a Latin defixio from Dax en las Landas (France, 4th/5th cent.): Leontio Leontio Deidio (= Didio) Jovino <in>bolaverunt (= imvolavenuni) manus pedis quicumqui lev(avit? anue (= amnue) ... (the rest is not clear). [AC] 


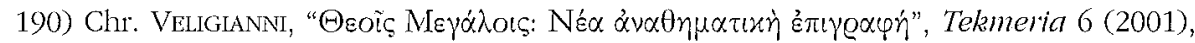
p. 14-21: Ed. pr. of a dedication (unknown provenance, Archaeological Museum of Serrai, AD 224). The text reads: : 'Eqouc $\delta x \sigma ' \mid \Delta \varepsilon i o u \eta^{\prime}$ [8th day of the month Deios in the year 224. C. Julius Blastus dedicated at his own expense a temple and ex-votos to the Great Gods Deso[---.]

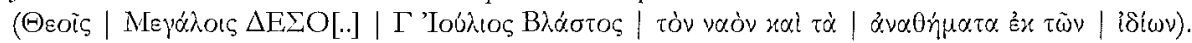
$\checkmark$. convincingly argues that the Great Gods of the inscription should not be identified with the Samothrakian Kabeiroi but with a local variant. The letters $\triangle E \Sigma O$ - probably belong to an ethnic -

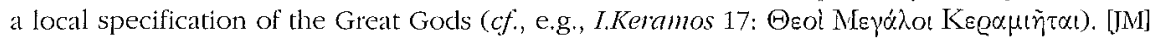

191) Chr. VENIRIFs, "Le couvercle du sarcophage de M. Sempronius Nikokratès 'poète et cithariste' (IGUR 1326)", in Musique et poésie, p. 109-121: V. studies the grave epigram for the poet and kitharist M. Sempronius Neikokrates (IGUR 1326; Rome, 2nd/3rd cent.), member

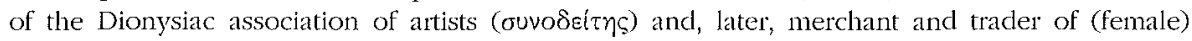
slaves. V. discusses the artistic activities of Nikokrates (poetic performances in accompaniment of his kithara), his membership in the Dionysiac association in Rome, and his participation in musical agons. Nikokrates' reference to the fact that even after his death the Muses hold his body is probably an allusion to the representation of Terpsichore and Polymnia on his sarcophagus. [We point to the eschatological ideas in the epigram: "I, Marcus Sempronius Nikokrates, used to be a man of the Muses, a poet and a kitharist, and indeed a member of an association (of attists). After I had laboured a lot in the deep sea and was exhausted by the journeys, then, my friends, I became a merchant of beautiful women. I had received the spirit/soul as a loan from heaven and having fulfilled the time I have returned it. Even after my death the Muses hold my body"]. [AC]

192) B. VIRgiLIO, "Roi, ville et temple dans les inscriptions de Labraunda", REA 103 (2001), p. 429-442: Based on the examination of seven royal and dynastic letters of Seleukos II, Olympichos and Philipp V (1.Labraunda 1-7) V. discusses the problematic relationship between the city of Mylasa and the priests of the sanctuary of Zeus Labraundos. It is remarkable that in almost every dispute between the city and the sanctuary, primarily on issues concerning land ownership, the kings and Olympichos decicled in favour of the city. V. suggests that this attinide aimed at favouring the Hellenized city against the obvious resistence of the indigenous priesthood against Hellenization [for an Italian version see "Re, città e tempio nelle iscrizioni di Labraunda", in B. VIrgiLIo (ed.), Studi ellenistici XIII, Pisa, 2001, p. 39-56]. [JM]

193) Chr. Wallner, "Zur Agonistik von Gaza", ZPE 135 (2001), p. 125-135: W. shows that there is no evidence for a sacred agon with the name Hadrianeia in Gaza. The reference to an

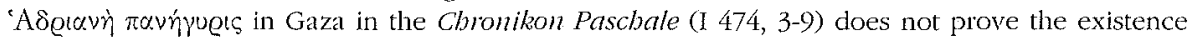
of such an agon, since the author does not use the term agon (which he used, e.g., for the Capitolia); the Hadriane panegyris in Gaza must have been a fair. The existence of Hadrianeia cannot be supported by the honorary inscription for the pankratiast $T$. Aelius Aurelius Menandros from Aphrodisias either (Ch. ROUECHÉ, Performers and Partisans at Aphrodisias in the Roman and Late Roman Periods, London, 1993, n ${ }^{\circ}$ 91, c. 230-250 AD). In this text Menandros' victory in Gaza is mentioned in a section which lists Menandros' victories in themides; consequently, in Gaza he did not win in a sacred agon (i.e., in the Hadrianreia). The existence of the agon Olympia in Gaza (hieros eiselastikos oikoumenikos agon isolympios) is known from a papyrus in Hermoupolis (AD 268; M. DRFW-BEAR, "Les athlètes d'Hermoupolis Magna et leur ville au $3^{\prime \prime}$ siècle", in B. Mandilaras (ed.), Proceedings of the XVIIIth International Congress of Papyrology, Athens, 1988, II, p. 229-235). This agon was certainly founded with the permission of an emperor, possibly on the occasion of his visit (probably Gordianus III, Valerianus, or Gallienus). [AC]

194) M.L. West, "The Fragmentary Homeric Hymn to Dionysus", ZPE 134 (2001), p. 111: W. edits different fragments of the Homeric Hymn to Dionysos preserved for the most part on papyri (Pap.Genav. 432; P.Oxy. 670; codex M) and attempts to reconstruct the complete content of the original Archaic hymn (bitth of the God, introduction in Olympos after being accepted by Hera, speech of Zeus ordaining the god's future honours). According to W., the text remained a very popular until the 4 th or even 5 th cent. AD. [JM] 
195) K.T. WITZAK, "L'hymne d'Épidaure à la mère des dieux", LEC 69 (2001), p. 23-33: W. presents a new critical edition of the Epidaurian hymn to the Mother of Gods (IG IV2 131), with French translation and commentary. [AC]

\section{Angelos CHANIOTIS}

Seminar für Alte Geschichte und Epigraphik Marstallhof 4

D - 69117 Heidleberg

angelos.chaniotis@urz.uni-beidelberg.de

\section{Jannis MytonOPOULOS}

Institut für Klassische Archäologie Franz Klein Gasse 1

A-1190 Wien

joamis.mylonopoulos@mivie.ac.at 